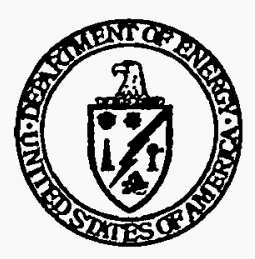

\title{
Directory of Financing Sources for Foreign Energy Projects
}

\section{September 1995}


Argonne National Laboratory, with facilities in the states of Illinois and Idaho, is owned by the United States government, and operated by the University of Chicago under the provisions of a contract with the Department of Energy.

\section{DISCLAIMER}

This report was prepared as an account of work sponsored by an agency of the United States Government. Neither the United States Government nor any agency thereof, nor any of their employees, makes any warranty, express or implied, or assumes any legal liability or responsibility for the accuracy, completeness, or usefulness of any information, apparatus, product, or process disclosed, or represents that its use would not infringe privately owned rights. Reference herein to any specific commercial product, process, or service by trade name, trademark, manufacturer, or otherwise, does not necessarily constitute or imply its endorsement, recommendation, or favoring by the United States Government or any agency thereof. The views and opinions of authors expressed herein do not necessarily state or reflect those of the United States Government or any agency thereof. 


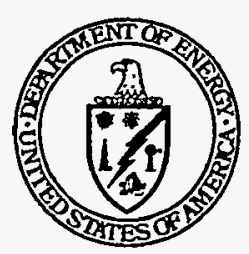

\section{Directory of Financing Sources for Foreign Energy Projects}

\section{September 1995}

Submitted to Office of National Security Policy Office for National Security and Environmental Restoration Policy U.S. Department of Energy Washington, DC 20585 


\section{PREFACE}

One goal of the Office of National Security Policy of the U.S. Department of Energy is to promote economic development, political stability, efficient use of energy, and sound environmental management practices in key foreign countries around the world. To achieve this goal, the Office of National Security Policy provides technical assistance to foreign entities with a view to help defense-related industries convert to commercial/civilian use; strengthen indigenous institutions that promote economic development; and seek alternative sources and uses of energy in support of broad national security interests, including minimizing the threat of nuclear proliferation.

In recognition of the importance of securing financing to support program initiatives under the above goal, the Office of National Security Policy has produced this Directory of Financing Sources for Foreign Energy Projects. The Directory reviews programs that offer financing from U.S. government agencies, multilateral organizations, public, private, and quasi-private investment funds, and local commercial and state development banks.

The main U.S. government agencies covered are the U.S. Agency for International Development (USAID), the Export-Import Bank of the United States (EXIM Bank), Overseas Private Investment Corporation (OPIC), U.S. Department of Energy, U.S. Department of Defense, and the U.S. Trade and Development Agency (TDA). Other U.S. Government Sources includes market funds that have been in part capitalized using U.S. government agency funds. Multilateral organizations include the World Bank, International Finance Corporation (IFC), Asian Development Bank (ADB), European Bank for Reconstruction and Development (EBRD), and various organizations of the United Nations.

The Directory lists available public, private, and quasi-private sources of financing in key emerging markets in the Newly Independent States and other developing countries of strategic interest to the U.S. Department of Energy. The sources of financing listed in this directory should be considered indicative rather than inclusive of all potential sources of financing. Initial focus is on the Russian Federation, Ukraine, India, China, and Pakistan. Separate self-contained sections have been developed for each of the countries to enable the user to readily access market-specific information and to support country-specific Departmental initiatives. For each country, the directory is organized to follow the project life cycle -from prefeasibility, feasibility, project finance, cofinancing, and trade finance, through to technical assistance and training. Programs on investment and export insurance are excluded.

Included as part of this Preface, Exhibits 1 and 2 provide a cross-reference of the various sources by country and type of financing. The main body of the Directory provides descriptions of each financing source. The descriptions of the financing sources include contact information which allows readers to effectively utilize the resources described.

Section A on "Feasibility Funding" covers funding sources for prefeasibility and feasibility studies. Once a project has been identified, prefeasibility funds can help defray the typically high-risk up-front costs of preparing initial project-specific information that demonstrates commercial viability and interest in the host country. Feasibility studies deal with the detailed evaluation of technical, marketing, and financial information required by private lenders and U.S. and multilateral organizations.

Section B on "Project Finance - Private Sector" reviews sources of financing that provide debt and equity financing directly to U.S. companies. This section includes private, public, and quasi-private investment funds. Each section covers U.S. government, multilateral, and indigenous sources (where information is available) of financing. Private investment funds are capitalized with funds from private sources while public investment funds are capitalized with funds from U.S. government agencies, like USAID, Department of Defense, etc. Quasi-private funds are those that have received initial capitalization from 
public or multi-lateral sources, like the EBRD or OPIC for example, but have raised additional capital from private sources.

-Section C on "Project Finance - Public Sector" covers sources of financing that lend directly to the public sector, i.e., government-to-government lending mostly for infrastructure development programs. The main sources of funding in this case are the World Bank, EBRD, and ADB.

Section D on "Cofinancing" refers to programs of multilateral development banks (MDBs), like the World Bank, EBRD, and ADB that leverage their financial resources with funds from external sources. External funds originate from either "official" or from "commercial" sources. Official cofinanciers can be other multilateral banks or organizations, like some agencies of the United Nations, bilateral finance institutions and development assistance agencies, and export credit agencies. Official cofinance partners provide additional sources of funding for public sector projects. Commercial cofinanciers can be banks or investment funds that cooperate with the MDBs in sharing the risk and structure the financing to develop private sector projects. Main cofinancing techniques include parallel and joint financing, export credit arrangements, loan syndication, and guarantees. Cofinancing techniques bring several advantages: increase amount of resources available to the MDBs in support of a wider range of projects, attract private capital into countries that do not meet the creditworthiness requirements of the international capital markets, and help diversify risk.

Section E on "Trade Finance" covers programs that offer financing for equipment, products, and in certain cases, services. This type of financing does not cover the entire project, just the procurement of equipment. The main source of financing is EXIM Bank. Local commercial and state development banks that provide domestic and international services are included under this section.

Section F on "Technical Assistance and Training" refers to those programs that provide a broad range of support to overall program initiatives or specific projects, such as advice on policy and legal reform, project preparation, sectoral studies, institutional development and local capacity building, human resources development, and accounting and management practices. Technical assistance programs could also include technical, economic, financial, environmental, legal due diligence in support of specific investments or projects.

As this directory covers sources of financing in emerging markets, information is time sensitive and subject to rapid change according to the political circumstances in the country, developments in financial markets, and shifts in policies and priorities of Western donors and investors. It is intended that this directory be updated periodically to keep pace with the changing dynamics of the region and the creation of new financing instruments and sources.

For comments, corrections, or suggestions regarding this directory, please contact the DOE Project Manager:

\author{
Dr. Fred H. Abel \\ Office of National Security Policy, PO-91 \\ Room 8F-089, Forrestal Building \\ U.S. Department of Energy \\ Washington, DC 20585 \\ Telephone: (202) 586-9399 \\ Fax: (202) 586-1737
}

This directory was written by Ms. Lydia La Ferla - Principal of La FERLA ASSOCIATES, Washington, DC under contract to the Special Projects Office (SPO) of Argonne National Laboratory with Dr. Ralph Stajdohar as Project Manager. Material provided to DOE directly by BCS, Incorporated has been included in this Preface as Exhibits 1 and 2. 
Exhibit 1

CROSS REFERENCE OF FINANCING SOURCES BY TYPE OF SERVICE AND COUNTRY

\begin{tabular}{|c|c|c|c|c|c|c|c|c|c|c|}
\hline & & $\because \because \vdots$ & iBitiry & NCING & & & PROJEC & NANCE - & ATE SE & $R$ \\
\hline & Russia & Ukraine & China & india & Pakistan & Russia & Ukraine & China & India & Pakistan \\
\hline U.SG Govemment Sources & & $\because$ & $\cdots$ & $\therefore$ & $\therefore$ & ${ }^{\prime}$ & & & $\because$ & 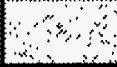 \\
\hline AIG Asian Infrastructure Fund & & & & & & & & $\bullet$ & $\bullet$ & $\bullet$ \\
\hline Brunswick Fund & & & & & & $\bullet$ & & & & \\
\hline $\begin{array}{l}\text { CARE Small Business Assistance Corporation } \\
\text { (CARESBAC) }\end{array}$ & & & & & & • & & & & \\
\hline $\begin{array}{l}\text { Committee on Energy Efficiency Commerce and Trade } \\
\text { (COEECT) }\end{array}$ & $\bullet$ & $\bullet$ & $\bullet$ & $\bullet$ & $\bullet$ & & & & & \\
\hline $\begin{array}{l}\text { Committee on Renewable Energy Commerce and } \\
\text { Trade (CORECT) }\end{array}$ & $\bullet$ & $\bullet$ & $\bullet$ & $\bullet$ & $\bullet$ & & & & & \\
\hline $\begin{array}{l}\text { Consortia of Amercan Businesses in the Newly } \\
\text { Independent States (CABNIS) }\end{array}$ & & & & & & & & & & \\
\hline Defense Enterprise Fund & & & & & & $\bullet$ & $\bullet$ & & & \\
\hline Environmental Enterprise Development Initiative & & & & $\bullet$ & & & & & & \\
\hline Environmental Enterprises Assistance Fund (EEAF) & & & & & & $\bullet$ & $\bullet$ & & $\bullet$ & \\
\hline Eurasia Foundation & & & & & & & & & & \\
\hline Fleming Russia Securities Fund & & & & & & $\bullet$ & & & & \\
\hline Framlington Russian Investment Fund & & & & & & $\bullet$ & & & & \\
\hline Far East Regional Venture Fund & & & & & & $\bullet$ & & & & \\
\hline First NIS Regional Fund & & & & & & $\bullet$ & $\mathbf{0}$ & & & \\
\hline First Russian Frontiers Trust PLC & & & & & & $\bullet$ & $\bullet$ & & & \\
\hline Fund for Large Enterprises in Russia (FLER) & & & & & & $\bullet$ & & & & \\
\hline Global Emerging Markets Leasing Fund & & & & & & & & $\bullet$ & & \\
\hline
\end{tabular}


Exhibit 1(Cont'd)

CROSS REFERENCE OF FINANCING SOURCES BY TYPE OF SERVICE AND COUNTRY

\begin{tabular}{|c|c|c|c|c|c|c|c|c|c|c|}
\hline & \multicolumn{5}{|c|}{ FEASIBLITY FINANCING } & \multicolumn{5}{|c|}{ PROJECT FINANCE - PRIVATE SECTOR } \\
\hline & Russia & Ukraine & China & India & Pakistan & Russia & Ukraine & China & India & Pakistan \\
\hline U.S. Govermment Sources & & & & & & . & & & & ; \\
\hline Global Environmental Emerging Markets Fund, L.P. & & & & & & $\bullet$ & $\bullet$ & & $\bullet$ & \\
\hline Global Power Investments Fund & & & & & & & & $\bullet$ & - & $\bullet$ \\
\hline $\begin{array}{l}\text { International Fund for Renewable Energy and Energy } \\
\text { Efficiency (IFREE) }\end{array}$ & - & - & & - & & & & & & \\
\hline Junction Investors Ltd. & & & & & & $\bullet$ & $\bullet$ & & & \\
\hline NCH Advisors & & & & & & $\bullet$ & $\bullet$ & & & \\
\hline New Europe East Investment Fund & & & & & & $\bullet$ & $\bullet$ & & & \\
\hline New Russian Small Business Investment Fund & & & & & & $\bullet$ & & & & \\
\hline Newstar Fund & & & & & & $\bullet$ & - & & & \\
\hline NIS Industrial Partnering Program & & & & & & & & & & \\
\hline Nunn-Lugar Funds & & & & & & & & & & \\
\hline OPIC & & & & & & $\bullet$ & $\bullet$ & & $\bullet$ & \\
\hline Peregrine Aslan Infrastructure Fund & & & & & & & & - & $\bullet$ & - \\
\hline Ploneer Fund & & & & & & - & & & & \\
\hline Red Tiger Investment Co. Ltd. & & & & & & - & & & & \\
\hline Russia and the Republics Equily Partners LP (RARE) & & & & & & - & & & & \\
\hline Russla Partners Fund & & & & & & - & - & & & \\
\hline Russla Technology Fund & & & & & & $\bullet$ & & & & \\
\hline Russia Value Fund, L.P. & & & & & & - & & & & \\
\hline Russia/NIS Major Projects Fund & & & & & & - & - & & & \\
\hline Russian Commodity Import Program (CIP) & & & & & & & & & & \\
\hline
\end{tabular}


Exhibit 1(Cont'd)

CROSS REFERENCE OF FINANCING SOURCES BY TYPE OF SERVICE AND COUNTRY

\begin{tabular}{|c|c|c|c|c|c|c|c|c|c|c|}
\hline & \multicolumn{5}{|c|}{ FEASIBILITY FINANCING } & \multicolumn{5}{|c|}{. PROJECT FINANCE - PRIVATE SECTOR } \\
\hline & Russia & Ukraine & China & India & Pakistan & Russia & Ukraine & China & India & Pakistan \\
\hline Us Qovenment sources & & & & $\because$ & $\therefore<$ & & & an & $\therefore$ & $\therefore$ \\
\hline Russian Sector Development Corporation & & & & & & - & & & & \\
\hline Russian Venture Capital Fund of America & & & & & & $\bullet$ & & & & \\
\hline Russian-American Enterprise Fund & & & & & & - & & & & \\
\hline Smolensk Regional Venture Fund & & & & & & $\bullet$ & & & & \\
\hline $\begin{array}{l}\text { Special American Business Internship Training Prog } \\
\text { (SABIT) }\end{array}$ & & & & & & & & & & \\
\hline St. Petersburg Regional Venture Fund & & & & & & $\bullet$ & & & & \\
\hline U.S. Agency for International Development (AID) & $\bullet$ & $\bullet$ & & & & & & & & \\
\hline U.S. Commercial Banks' & & & & & & & & & & \\
\hline U.S. Department of Agriculture (USDA) & & & & & & & & & & \\
\hline U.S. Export-Import Bank (EXIM) & & & & & & & & & & \\
\hline $\begin{array}{l}\text { U.S. Export-Import Bank's Engineering Multipllier } \\
\text { Program }\end{array}$ & - & & - & - & - & & & & & \\
\hline U.S. Export-Import Bank's Project Finance Program & & & & & & & & - & - & - \\
\hline U.S. Small Business Administration (SBA) & & & & & & & & & & \\
\hline U.S. Trade and Development Agency (TDA) & $\bullet$ & - & & $\bullet$ & & & & & & \\
\hline Ukraine Fund & & & & & & & - & & & \\
\hline Urals Regional Venture Fund & & & & & & $\bullet$ & & & & \\
\hline Western NIS Enterprise Fund & & & & & & & - & & & \\
\hline
\end{tabular}

'U.S. Commercial Banks include: Bank of America, Chase Manhattan Bank, Chemical Banking Corporation, Citibank, Credit Suisse-First Boston, and West Merchant Bank Limited.

Note: Many funds listed under "U.S. Government Sources" are capitalized in part by the U.S. government. 
Exhibit 1(Cont'd)

CROSS REFERENCE OF FINANCING SOURCES BY TYPE OF SERVICE AND COUNTRY

\begin{tabular}{|c|c|c|c|c|c|c|c|c|c|c|}
\hline & \multicolumn{5}{|c|}{ FEASIBILITY FINANCING } & \multicolumn{5}{|c|}{ PROJECT FINANCE - PRIVATE SECTOR } \\
\hline & Russia & Ukraine & China & India & Pakistan & Russia & Ukraine & China & India & Pakistan \\
\hline Mullitateteral sources & & & & & & & & & & \\
\hline Asian Development Bank (ADB) & & & - & $\bullet$ & $\bullet$ & & & & & \\
\hline $\begin{array}{l}\text { European Bank for Reconstruction and Development } \\
\text { Bank (EBRD) }\end{array}$ & - & $\bullet$ & & & & - & - & & & \\
\hline $\begin{array}{l}\text { European Bank for Reconstruction and Development } \\
\text { (EBRD) Small Business Fund }\end{array}$ & & & & & & - & & & & \\
\hline Export-Import Bank of Japan (JEXIM) & & & & & & & & & & \\
\hline Global Environmental Facility & & & & & & & & & & \\
\hline $\begin{array}{l}\text { International Bank for Reconstruction and Development } \\
\text { (World Bank) }\end{array}$ & & & & & & & & & & \\
\hline International Finance Corporation (IFC) & & & & & & $\bullet$ & $\bullet$ & $\bullet$ & - & $\bullet$ \\
\hline Nuclear Safety Account & & & & & & & & & & \\
\hline Russian Energy Savings Fund & $\bullet$ & & & & & & & & & \\
\hline World Bank & & & & & & & & & & \\
\hline
\end{tabular}


Exhibit 1 (Cont'd)

CROSS REFERENCE OF FINANCING SOURCES BY TYPE OF SERVICE AND COUNTRY

\begin{tabular}{|c|c|c|c|c|c|c|c|c|c|c|}
\hline & & PAOAECT & ANCEPL & $O S E C$ & & & $c$ & NANCIN & $\because$ & $i$ \\
\hline & Russia & Ukraine & China & Indla & Pakistan & Russia & Ukralne & China & India & Pakistan \\
\hline U.S. Government Sources : & $\therefore$ & & $1 \quad$ & $\because$ & & 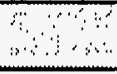 & & & $\therefore$ & \\
\hline AIG Aslan Infrastructure Fund & & & & & & & & & & \\
\hline Brunswick Fund & & & & & & & & & & \\
\hline CARE Small Business Assistance & & & & & & & & & & \\
\hline Committee on Energy Efficiency & & & & & & & & & & \\
\hline $\begin{array}{l}\text { Committee on Renewable Energy } \\
\text { (CORECT) }\end{array}$ & & & & & & & & & & \\
\hline $\begin{array}{l}\text { Consortia of American Businesse } \\
\text { States (CABNIS) }\end{array}$ & & & & & & & & & & \\
\hline Defense Enterprise Fund & & & & & & & & & & \\
\hline Environmental Enterprise Develo & & & & & & & & & & \\
\hline Environmental Enterprises Assist & & & & & & & & & & \\
\hline Eurasia Foundation & & & & & & & & & & \\
\hline Fleming Russia Securities Fund & & & & & & & & & & \\
\hline Framlington Russian Investment I & & & & & & & & & & \\
\hline Far East Regional Venture Fund & & & & & & & & & & \\
\hline First NIS Regional Fund & & & & & & & & & & \\
\hline First Russian Frontiers Trust PLC & & & & & & & & & & \\
\hline Fund for Large Enterprises in Rus & & & & & & & & & & \\
\hline Global Emerging Markets Leasing & & & & & & & & & & \\
\hline Global Environmental Emerging $\mathrm{n}$ & & & & & & & & & & \\
\hline Global Power Investments Fund & & & & & & & & & & \\
\hline
\end{tabular}


Exhibit 1(Cont'd)

CROSS REFERENCE OF FINANCING SOURCES BY TYPE OF SERVICE AND COUNTRY

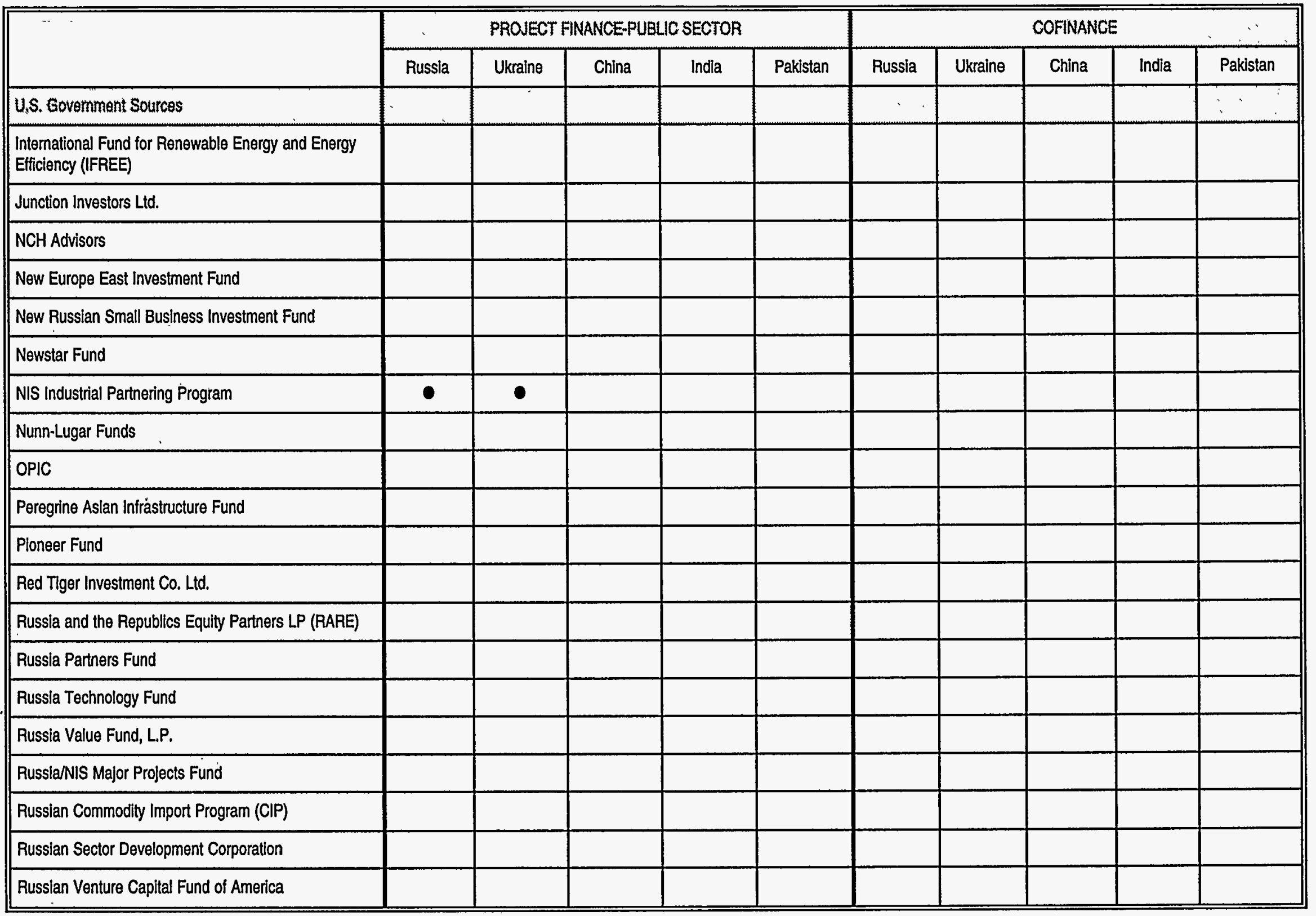


Exhibit 1(Cont'd)

CROSS REFERENCE OF FINANCING SOURCES BY TYPE OF SERVICE AND COUNTRY

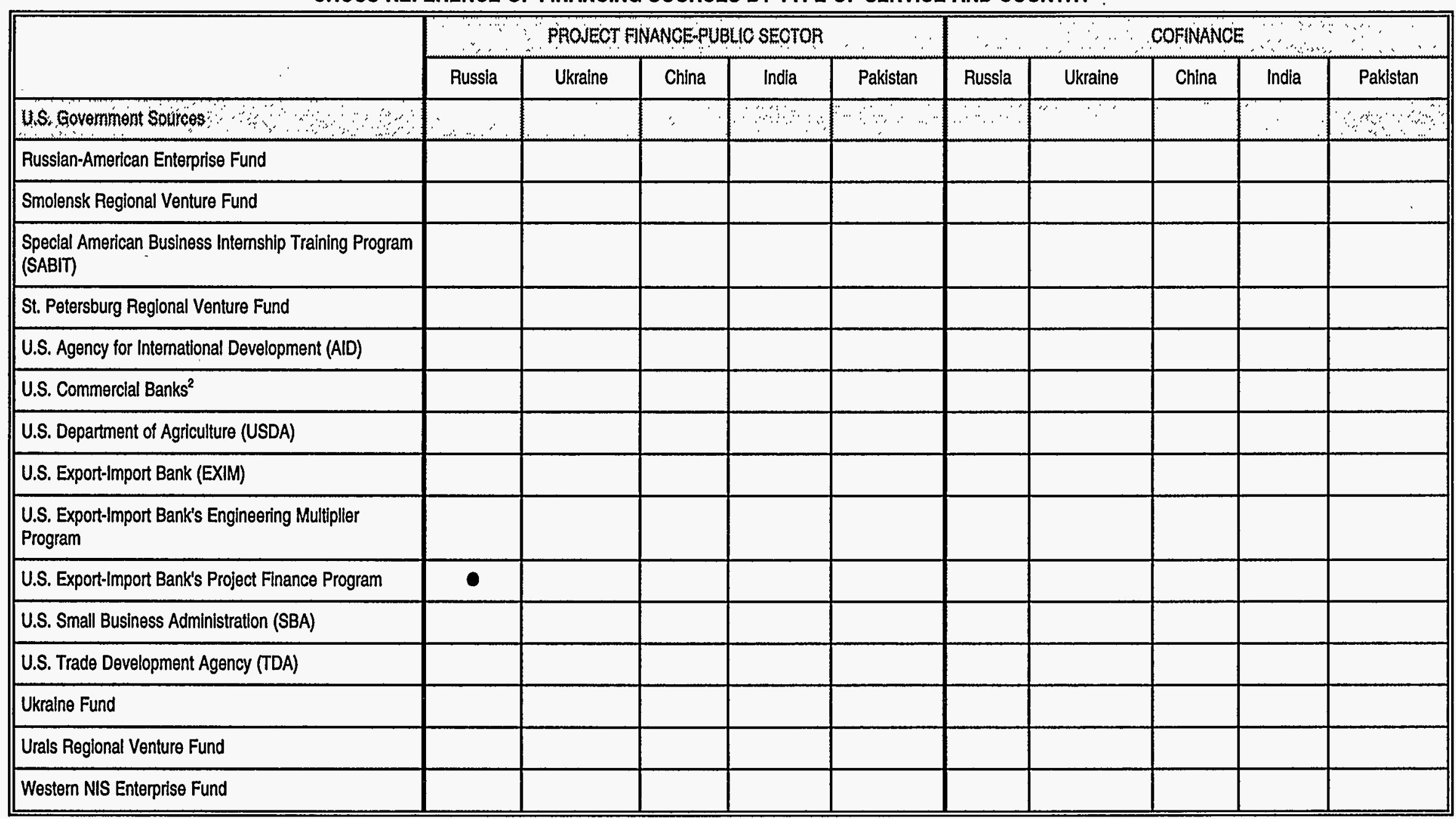

${ }^{2}$ U.S. Commercial Banks include: Bank of America, Chase Manhattan Bank, Chemical Banking Corporation, Citibank, Credit Suisse-First Boston, and West Merchant Bank Limited.

Note: Many funds listed under "U.S. Govemment Sources" are capitalized in part by the U.S. government. 
Exhibit 1(Cont'd)

CROSS REFERENCE OF FINANCING SOURCES BY TYPE OF SERVICE AND COUNTRY

\begin{tabular}{|c|c|c|c|c|c|c|c|c|c|c|}
\hline & \multicolumn{5}{|c|}{ PROJECT FNANCE-PUBLIC SECTOR } & \multicolumn{5}{|c|}{ COFINANCE } \\
\hline & Russla & Ukraine & China & India & Pakistan & Russia & Ukraine & China & India & Pakistan \\
\hline Mutulatereral Soumes a & . ? & & & & & & & & & \\
\hline Asian Development Bank (ADB) & & & - & $\bullet$ & $\bullet$ & & & - & $\bullet$ & $\bullet$ \\
\hline $\begin{array}{l}\text { European Bank for Reconstruction and Development } \\
\text { Bank (EBRD) }\end{array}$ & & & & & & - & - & & & \\
\hline $\begin{array}{l}\text { European Bank for Reconstruction and Development } \\
\text { (EBRD) Small Business Fund }\end{array}$ & & & & & & & & & & \\
\hline Export-Import Bank of Japan (JEXIM) & & & & & & & & & & \\
\hline Global Environmental Facility & - & - & - & - & - & & & & & \\
\hline $\begin{array}{l}\text { Intermational Bank for Reconstruction and Development } \\
\text { (World Bank) }\end{array}$ & - & - & - & - & - & - & - & - & - & - \\
\hline International Finance Corporation (IFC) & & & & & & 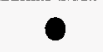 & $\bullet$ & $\bullet$ & $\bullet$ & $\bullet$ \\
\hline Nuclear Safety Account & $\bullet$ & $\bullet$ & & & & & & & & \\
\hline Russian Energy Savings Fund & - & & & & & & & & & \\
\hline World Bank & & & & & & & & & & \\
\hline
\end{tabular}


Exhibit 1 (Cont'd)

CROSS REFERENCE OF FINANCING SOURCES BY TYPE OF SERVICE AND COUNTRY

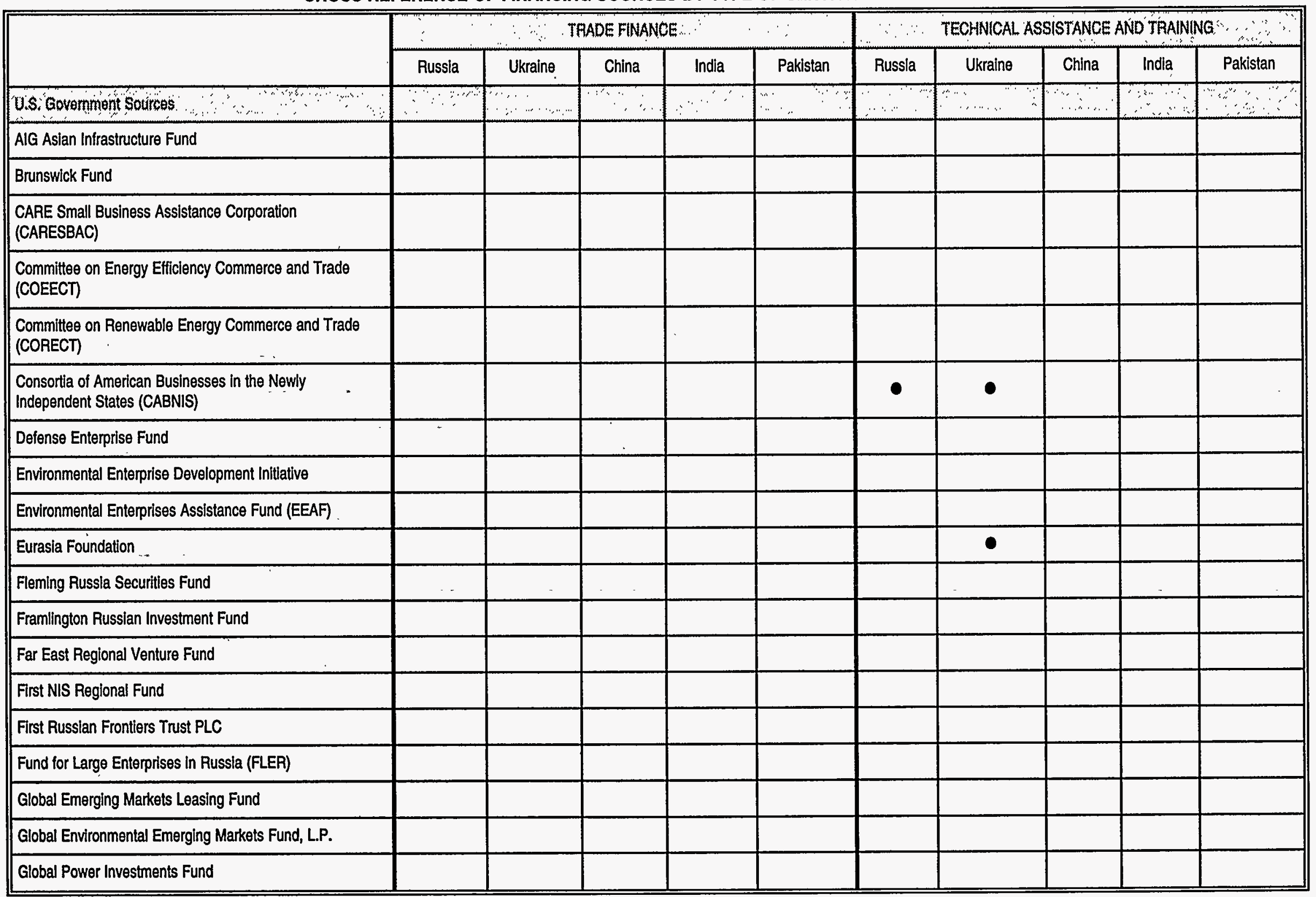


Exhibit 1(Cont'd)

CROSS REFERENCE OF FINANCING SOURCES BY TYPE OF SERVICE AND COUNTRY

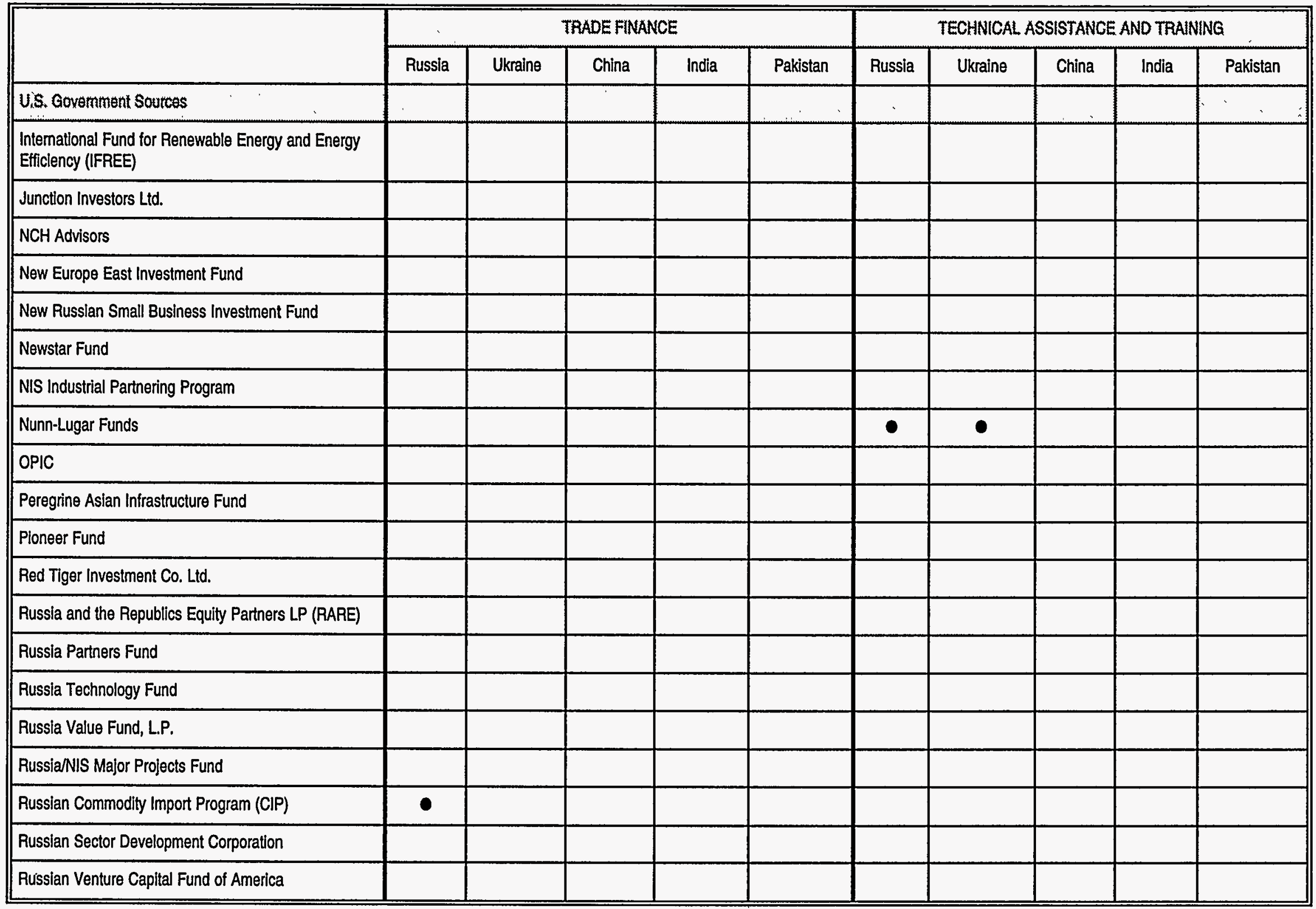


Exhibit 1(Cont'd)

CROSS REFERENCE OF FINANCING SOURCES BY TYPE OF SERVICE AND COUNTRY

\begin{tabular}{|c|c|c|c|c|c|c|c|c|c|c|}
\hline & \multicolumn{5}{|c|}{ TRADE FINANCE } & \multicolumn{5}{|c|}{ TECHNICAL ASSISTANCE AND TRAINING } \\
\hline U.S Government Sources & $\because$ & $\because$ & 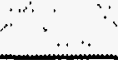 & $\because \cdots$ & .. & $\therefore \cdots$ & $\therefore \cdots$ & & $\therefore$ & $\because$ \\
\hline Russian-American Enterprise Fund & & & & & & & & & & \\
\hline Smolensk Regional Venture Fund & & & & & & & & & & \\
\hline $\begin{array}{l}\text { Special American Business Internship Training Program } \\
\text { (SABIT) }\end{array}$ & & & & & & - & - & & & \\
\hline St. Petersburg Regional Venture Fund & & & & & & & & & & \\
\hline U.S. Agency for International Development (AID) & 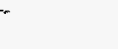 & & & & & - & - & & - & \\
\hline U.S. Commercial Banks ${ }^{3}$ & - & & & & & & & & & \\
\hline U.S. Department of Agriculture (USDA) & - & & & & & - & - & & & \\
\hline U.S. Export-Import Bank (EXIM) & - & & - & - & - & & & & & \\
\hline U.S. Small Business Administration (SBA) & - & - & & & & & & & & \\
\hline U.S. Trade Development Agency (TDA) & & & & & & & & & & \\
\hline Ukraine Fund & & & & & & & & & & \\
\hline Urals Regional Venture Fund & & & & & & & & & & \\
\hline Western NIS Enterprise Fund & & & & & & & & & & \\
\hline
\end{tabular}

3U.S. Commercial Banks include: Bank of America, Chase Manhattan Bank, Chemical Banking Corporation, Citibank, Credit Suisse-First Boston, and West Merchant Bank Limited.

Note: Many funds listed under "U.S. Government Sources" are capitalized in part by the U.S. government. 
Exhibit 1(Cont'd)

CROSS REFERENCE OF FINANCING SOURCES BY TYPE OF SERVICE AND COUNTRY

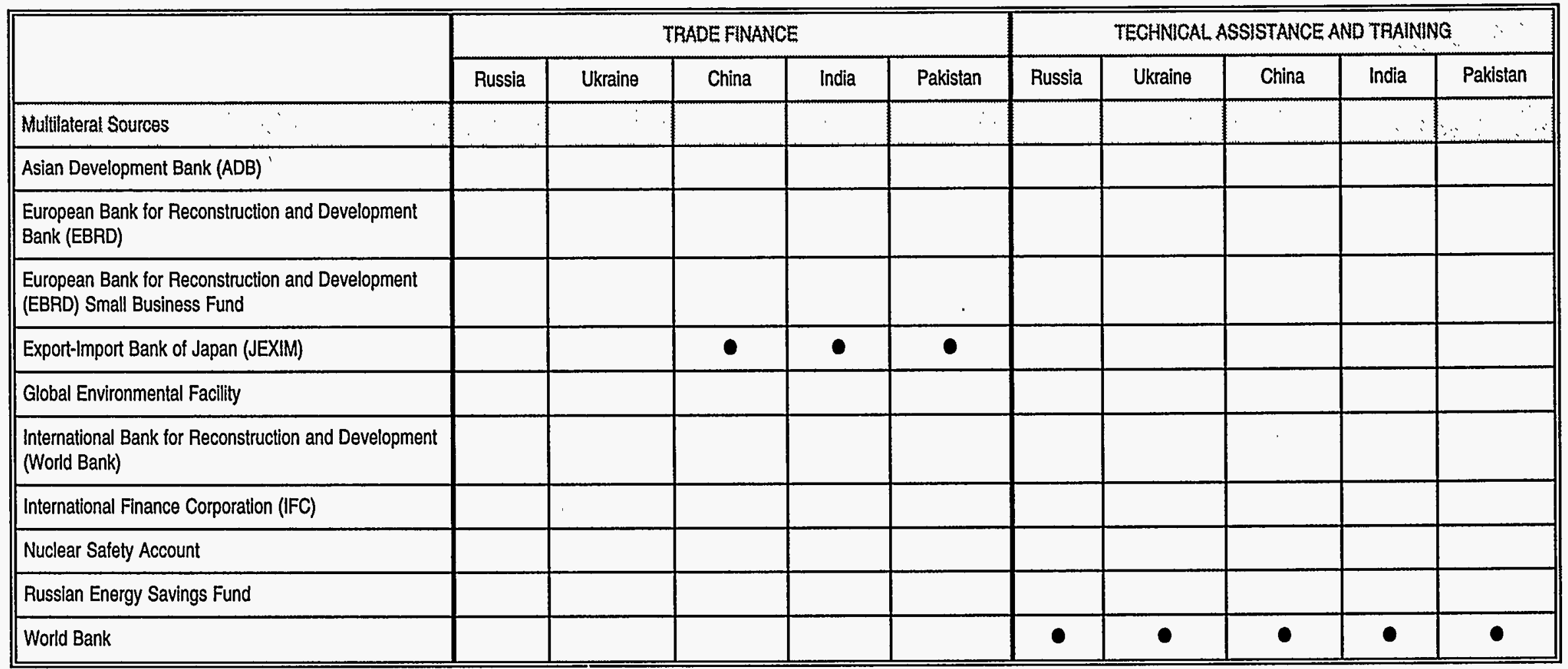




\section{Exhibit 2}

\section{IN-COUNTRY ENERGY FINANCING SOURCES}

\begin{tabular}{|c|c|c|c|}
\hline \multicolumn{2}{|c|}{ RUSSSIA } & \multicolumn{2}{|c|}{ UKRAINE,,} \\
\hline $\begin{array}{c}\text { Trade Finance } \\
0\end{array}$ & $\begin{array}{l}\text { Technicar Assistance and } \\
\text { Tratning }\end{array}$ & Trade Finance & $\begin{array}{l}\text { Technical Assistance and } \\
\text { Tratning }\end{array}$ \\
\hline $\begin{array}{l}\text { Rosvneshtorgbank (VTB) - } \\
\text { Russian for Foreign Trade } \\
\text { Vnesheconombank (VEB) } \\
\text { - Bank for Foreign } \\
\text { Economic Affairs } \\
\text { International Moscow } \\
\text { Bank } \\
\text { Moscow Import-Export } \\
\text { Bank } \\
\text { Inkombank } \\
\text { Mosbusinessbank (Mos- } \\
\text { cow Bank for Business } \\
\text { Promotion) } \\
\text { Moscow Industrial Bank } \\
\text { Tokobank }\end{array}$ & $\begin{array}{l}\text { Moscow Center for Energy } \\
\text { Efficiency (CENEf) }\end{array}$ & $\begin{array}{l}\text { Credit Lyonnais } \\
\text { Deutsche Bank } \\
\text { Banque Nationale de Paris } \\
\text { Dresdner Bank } \\
\text { First Ukrainian International } \\
\text { Bank } \\
\text { Ukreximbank - State } \\
\text { Export-Import Bank of } \\
\text { Ukraine } \\
\text { Ukrsotsbank } \\
\text { Oshadbank Ukraina } \\
\text { Bank Ukraina } \\
\text { Prominvestbank of Ukraine } \\
\text { West-Ukrainian } \\
\text { Commercial Bank }\end{array}$ & $\begin{array}{l}\text { ARENA-ECO (Ukrainian } \\
\text { Center for Energy } \\
\text { Efficiency and Envi- } \\
\text { ronmental Protection) }\end{array}$ \\
\hline
\end{tabular}


Exhibit 2 (Cont'd)

IN-COUNTRY ENERGY FINANCING SOURCES

\begin{tabular}{|c|c|c|c|}
\hline & $\because$ CHINA & & INDIA \\
\hline $\begin{array}{c}\text { Project Finance - Public } \\
\text { Sector }\end{array}$ & $\therefore$ Trade Finance & $\begin{array}{l}\text { Technical Assistance and } \\
\therefore \quad \text { Training }\end{array}$ & Trade Finanice \\
\hline $\begin{array}{l}\text { State Development Bank } \\
\text { (SDBC) } \\
\text { Agricultural Development } \\
\text { Bank of China (ADBC) } \\
\text { Export-Import Bank of } \\
\text { China (EIB) }\end{array}$ & $\begin{array}{l}\text { Agriculture Bank of China } \\
\text { Bank of China } \\
\text { China Investment Bank } \\
\text { CITIC Industrial Bank } \\
\text { Guangdong Development } \\
\text { Bank } \\
\text { Shenzhen Develop Bank } \\
\text { The Industrial \& } \\
\text { Commercial Bank of China } \\
\text { People's Construction } \\
\text { Bank of China } \\
\text { AND Amro Bank NV } \\
\text { Bank of Tokyo Ltd. } \\
\text { Banque Indosuez } \\
\text { Citibank, N.A. } \\
\text { Dresdner Bank AG } \\
\text { Hongkong and Shanghai } \\
\text { Banking Corporation } \\
\text { J.P. Morgan \& Co. Inc. } \\
\text { Mitsubishi Bank Limited } \\
\text { Sanwa Bank Linited } \\
\text { Societe Generale }\end{array}$ & $\begin{array}{l}\text { Beijing Energy Efficiency } \\
\text { Center (BECon) }\end{array}$ & $\begin{array}{l}\text { Export import Bank of } \\
\text { India } \\
\text { State Bank of India } \\
\text { Industrial Credit \& Invest- } \\
\text { ment Corporation } \\
\text { Industrial Development } \\
\text { Bank of India } \\
\text { Industrial finance Corpora- } \\
\text { tion of India } \\
\text { ANZ Grindlays Bank } \\
\text { Bank of New York } \\
\text { Chemical Bank } \\
\text { Citibank International }\end{array}$ \\
\hline
\end{tabular}


Exhibit 2 (Cont'd)

IN-COUNTRY ENERGY FINANCING SOURCES

\begin{tabular}{|c|c|}
\hline Project Finance Public socto & Ty Tade Finance \\
\hline $\begin{array}{l}\text { Agricultural Development Bank of Pakistan } \\
\text { Industrial Development Bank of Pakistan } \\
\text { Investment Corporation of Pakistan } \\
\text { National Bank of Pakistan (NBP) } \\
\text { National Investment (Unit Trust) Ltd. } \\
\text { Pakistan Industrial Credit and Investment Corporation } \\
\text { Ltd. } \\
\text { Pak-Libya Holding Co. Ltd. } \\
\text { Saudi pak Industrial and Agricultural Investment Co. } \\
\text { (Pvt.) } \\
\text { State Bank of Pakistan Ltd. } \\
\text { United Bank Ltd. }\end{array}$ & $\begin{array}{l}\text { Allied Bank of Pakistan Ltd. } \\
\text { Askari Commercial Bank Ltd. } \\
\text { Habib Bank Ltd. } \\
\text { Muslim Commercial Bank Ltd. } \\
\text { Prime Commercial Bank Ltd. } \\
\text { Soneri Bank Ltd. } \\
\text { ABN-AMRO Bank NV } \\
\text { ANZ Grindlays Bank PLC } \\
\text { American Express Bank Ltd. } \\
\text { Bank of America National Trust and Savings } \\
\text { Association } \\
\text { Bank of Tokyo Ltd. } \\
\text { Banque Indosues } \\
\text { CS First Boston } \\
\text { Chase Manhattan Bank } \\
\text { Citibank NA } \\
\text { Deutsche Bank AG } \\
\text { GE Capitol } \\
\text { The Hong Kong and Shanghai Banking Corporation } \\
\text { Ltd. } \\
\text { Kidder, Peabody \& Co. } \\
\text { Merrill Lynch \& Co. } \\
\text { Salomon Brothers } \\
\text { Smith Barney Asia, Inc. } \\
\text { Standard Charter Bank } \\
\text { Sete Generale } \\
\text { Sal }\end{array}$ \\
\hline
\end{tabular}




\section{TABLE OF CONTENTS}

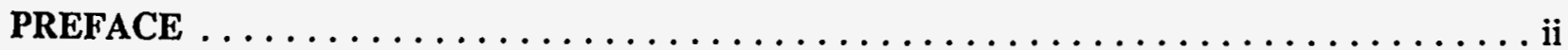

1. RUSSIAN FEDERATION

A. Feasibility Financing $\ldots \ldots \ldots \ldots \ldots \ldots \ldots \ldots \ldots \ldots \ldots \ldots \ldots \ldots \ldots$

A.1. U.S. Government Sources $\ldots \ldots \ldots \ldots \ldots \ldots \ldots \ldots \ldots \ldots \ldots \ldots$. . . . . . .

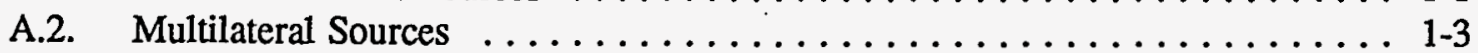

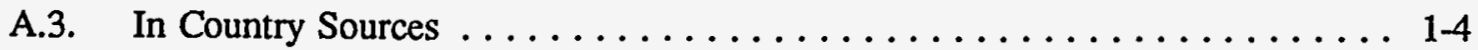

B. Project Finance - Private Sector . . . . . . . . . . . . . . . . . .

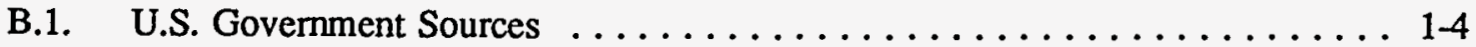

B.2. Multilateral Sources $\ldots \ldots \ldots \ldots \ldots \ldots \ldots \ldots \ldots \ldots \ldots \ldots \ldots$ 1-16

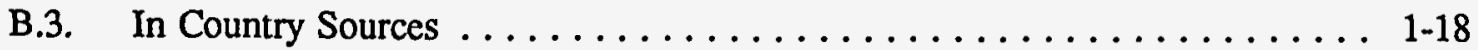

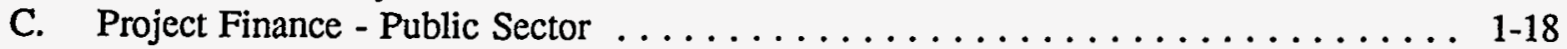

C.1. U.S. Government Sources $\ldots \ldots \ldots \ldots \ldots \ldots \ldots \ldots \ldots \ldots \ldots \ldots \ldots$

C.2. Multilateral Sources $\ldots \ldots \ldots \ldots \ldots \ldots \ldots \ldots \ldots \ldots \ldots \ldots \ldots \ldots$

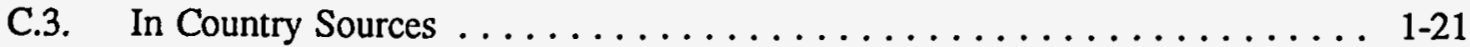

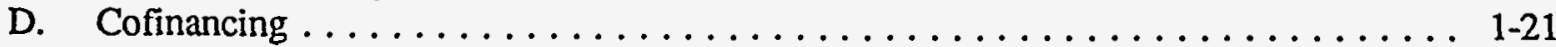

D.1. U.S. Government Sources $\ldots \ldots \ldots \ldots \ldots \ldots \ldots \ldots \ldots \ldots \ldots \ldots$. . . . . . . . . . .

D.2. Multilateral Sources ............................ 1-21

D.3. In Country Sources . . . . . . . . . . . . . . . . . . . . . . 1-23

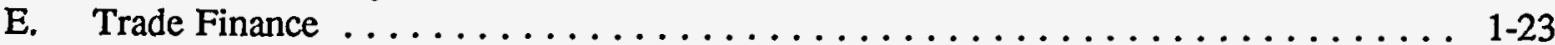

E.1. U.S. Government Sources . . . . . . . . . . . . . . . . . . . . . 1-23

E.2. Multilateral Sources $\ldots \ldots \ldots \ldots \ldots \ldots \ldots \ldots \ldots \ldots \ldots \ldots \ldots \ldots$ 1-27

E.3. In Country Sources . . . . . . . . . . . . . . . . . . . . . . . . 1-27

F. Technical Assistance \& Training . . . . . . . . . . . . . . . . . . . . 1-29

F.1. U.S. Government Sources . . . . . . . . . . . . . . . . . . . 1-29

F.2. Multilateral Sources . . . . . . . . . . . . . . . . . . . . 1-33

F.3. In Country Sources $\ldots \ldots \ldots \ldots \ldots \ldots \ldots \ldots \ldots \ldots \ldots \ldots$. . . . . . . . . . . . .

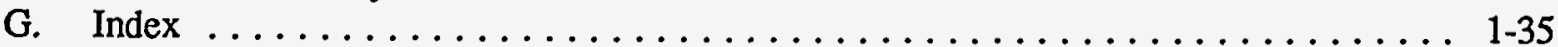

2. UKRAINE

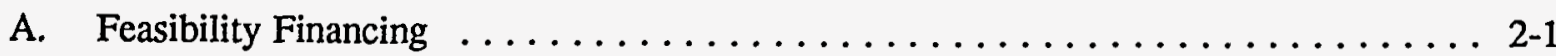

A.1. U.S. Government Sources $\ldots \ldots \ldots \ldots \ldots \ldots \ldots \ldots \ldots \ldots \ldots \ldots$. . . . . . . . . . .

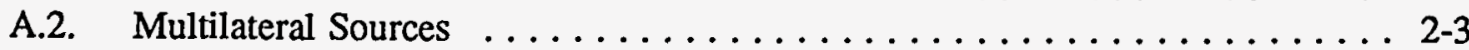

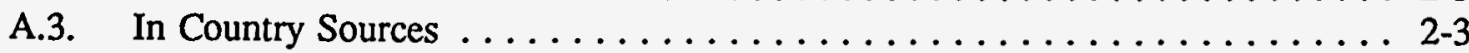

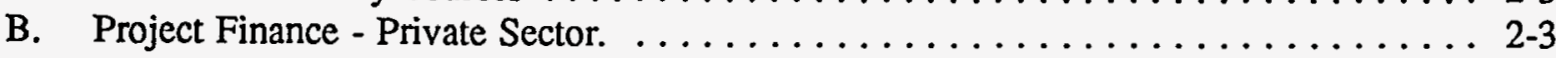

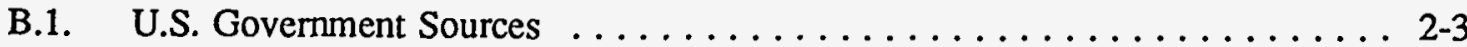

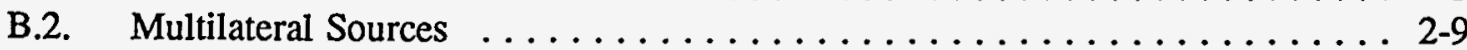

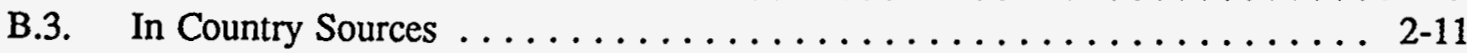

C. Project Finance - Public Sector . . . . . . . . . . . . . . . . 2-11

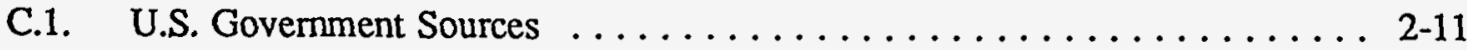

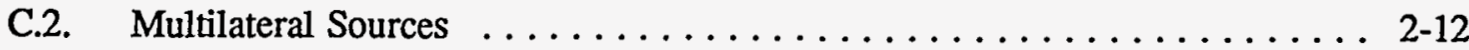

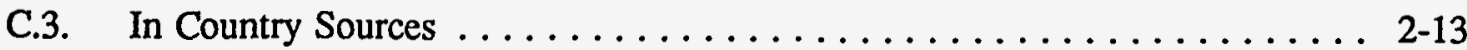

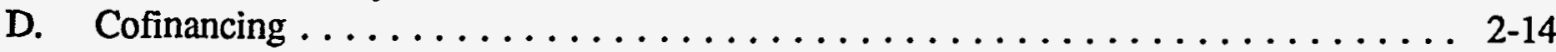

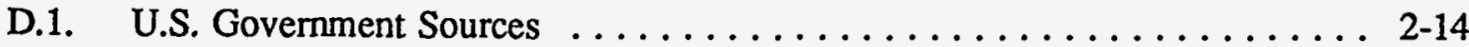

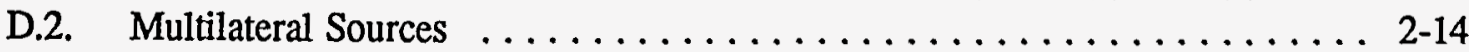

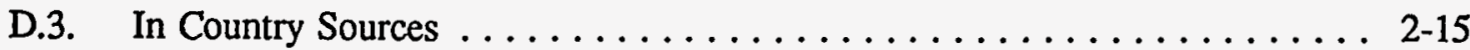




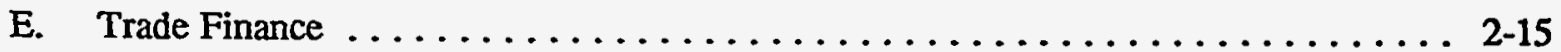

E.1. U.S. Government Sources $\ldots \ldots \ldots \ldots \ldots \ldots \ldots \ldots \ldots \ldots, 2-15$

E.2. Multilateral Sources $\ldots \ldots \ldots \ldots \ldots \ldots \ldots \ldots \ldots \ldots \ldots \ldots \ldots \ldots \ldots \ldots, 2-15$

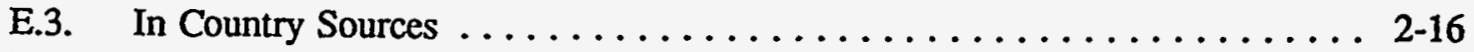

F. Technical Assistance \& Training $\ldots \ldots \ldots \ldots \ldots \ldots \ldots \ldots \ldots \ldots \ldots \ldots \ldots \ldots \ldots \ldots \ldots, 17$

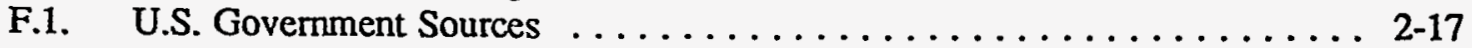

F.2. Multilateral Sources $\ldots \ldots \ldots \ldots \ldots \ldots \ldots \ldots \ldots \ldots \ldots \ldots \ldots \ldots \ldots \ldots, 2-21$

F.3. In Country Sources $\ldots \ldots \ldots \ldots \ldots \ldots \ldots \ldots \ldots \ldots \ldots \ldots \ldots, 2-21$

G. Index $\ldots \ldots \ldots \ldots \ldots \ldots \ldots \ldots \ldots \ldots \ldots \ldots \ldots \ldots \ldots \ldots \ldots \ldots \ldots \ldots, 222$

3. CHINA

A. Feasibility Financing $\ldots \ldots \ldots \ldots \ldots \ldots \ldots \ldots \ldots \ldots \ldots \ldots \ldots \ldots \ldots \ldots \ldots, 1$

A.1. U.S. Government Sources $\ldots \ldots \ldots \ldots \ldots \ldots \ldots \ldots \ldots \ldots \ldots \ldots, \ldots \ldots \ldots, 1$

A.2. Multilateral Sources $\ldots \ldots \ldots \ldots \ldots \ldots \ldots \ldots \ldots \ldots \ldots \ldots \ldots \ldots \ldots \ldots \ldots \ldots, 2$

A.3. In Country Sources $\ldots \ldots \ldots \ldots \ldots \ldots \ldots \ldots \ldots \ldots \ldots \ldots \ldots \ldots \ldots \ldots \ldots \ldots, 2$

B. Project Finance - Private Sector. $\ldots \ldots \ldots \ldots \ldots \ldots \ldots \ldots \ldots \ldots \ldots \ldots \ldots \ldots, 3-3$

B.1. U.S. Government Sources $\ldots \ldots \ldots \ldots \ldots \ldots \ldots \ldots \ldots \ldots \ldots$ 3-3

B.2. Multilateral Sources $\ldots \ldots \ldots \ldots \ldots \ldots \ldots \ldots \ldots \ldots \ldots \ldots, 3-5$

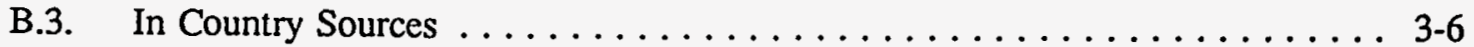

C. Project Finance - Public Sector $\ldots \ldots \ldots \ldots \ldots \ldots \ldots \ldots \ldots \ldots \ldots \ldots \ldots \ldots \ldots \ldots$

C.1. U.S. Government Sources $\ldots \ldots \ldots \ldots \ldots \ldots \ldots \ldots \ldots \ldots \ldots \ldots, \ldots \ldots$

C.2. Multilateral Sources $\ldots \ldots \ldots \ldots \ldots \ldots \ldots \ldots \ldots \ldots \ldots \ldots \ldots, \ldots \ldots \ldots$

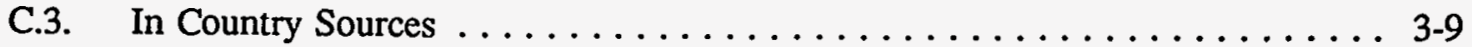

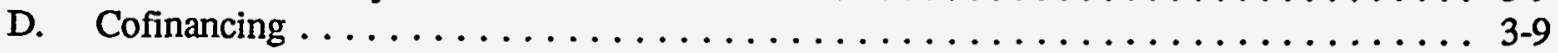

D.1. U.S. Government Sources $\ldots \ldots \ldots \ldots \ldots \ldots \ldots \ldots \ldots \ldots \ldots \ldots$. $3-9$

D.2. Multilateral Sources $\ldots \ldots \ldots \ldots \ldots \ldots \ldots \ldots \ldots \ldots \ldots, 3-10$

D.3. In Country Sources $\ldots \ldots \ldots \ldots \ldots \ldots \ldots \ldots \ldots \ldots \ldots \ldots \ldots, 3-11$

E. Trade Finance $\ldots \ldots \ldots \ldots \ldots \ldots \ldots \ldots \ldots \ldots \ldots \ldots \ldots \ldots \ldots \ldots \ldots \ldots \ldots, 11$

E.1. U.S. Government Sources $\ldots \ldots \ldots \ldots \ldots \ldots \ldots \ldots \ldots \ldots \ldots$ 3-11

E.2. Multilateral Sources $\ldots \ldots \ldots \ldots \ldots \ldots \ldots \ldots \ldots \ldots \ldots, 3-12$

E.3. In Country Sources $\ldots \ldots \ldots \ldots \ldots \ldots \ldots \ldots \ldots \ldots \ldots, 3-12$

F. Technical Assistance \& Training $\ldots \ldots \ldots \ldots \ldots \ldots \ldots \ldots \ldots \ldots \ldots \ldots, \ldots \ldots \ldots$

F.1. U.S. Government Sources $\ldots \ldots \ldots \ldots \ldots \ldots \ldots \ldots \ldots \ldots \ldots$. $3-16$

F.2. Multilateral Sources $\ldots \ldots \ldots \ldots \ldots \ldots \ldots \ldots \ldots \ldots \ldots \ldots, \ldots \ldots \ldots, 17$

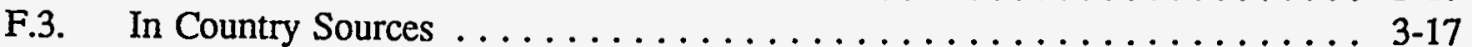

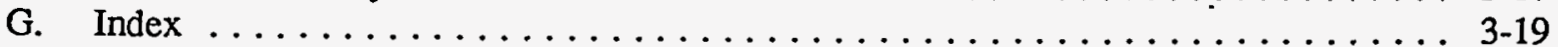

4. INDIA

A. Feasibility Financing $\ldots \ldots \ldots \ldots \ldots \ldots \ldots \ldots \ldots \ldots \ldots \ldots \ldots, \ldots \ldots \ldots, 1$

A.1. U.S. Government Sources $\ldots \ldots \ldots \ldots \ldots \ldots \ldots \ldots \ldots \ldots \ldots$. 4-1

A.2. Multilateral Sources $\ldots \ldots \ldots \ldots \ldots \ldots \ldots \ldots \ldots \ldots \ldots, \ldots \ldots \ldots, 3$

A.3. In Country Sources $\ldots \ldots \ldots \ldots \ldots \ldots \ldots \ldots \ldots \ldots \ldots \ldots \ldots, 4,4$

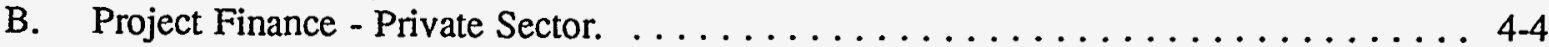

B.1. U.S. Government Sources $\ldots \ldots \ldots \ldots \ldots \ldots \ldots \ldots \ldots \ldots, 4-4$

B.2. Multilateral Sources $\ldots \ldots \ldots \ldots \ldots \ldots \ldots \ldots \ldots \ldots \ldots \ldots, 4-7$

B.3. In Country Sources $\ldots \ldots \ldots \ldots \ldots \ldots \ldots \ldots \ldots \ldots \ldots, 4,8$

C. Project Finance - Public Sector $\ldots \ldots \ldots \ldots \ldots \ldots \ldots \ldots \ldots \ldots \ldots \ldots, 4,8$

C.1. U.S. Government Sources $\ldots \ldots \ldots \ldots \ldots \ldots \ldots \ldots \ldots \ldots \ldots, 4.8$

C.2. Multilateral Sources $\ldots \ldots \ldots \ldots \ldots \ldots \ldots \ldots \ldots \ldots \ldots \ldots \ldots, 4-9$

C.3. In Country Sources $\ldots \ldots \ldots \ldots \ldots \ldots \ldots \ldots \ldots \ldots \ldots \ldots \ldots \ldots \ldots \ldots, 11$ 


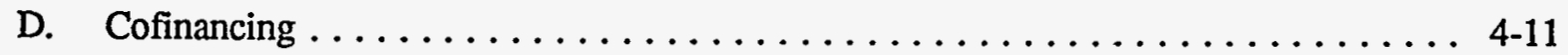

D.1. U.S. Government Sources $\ldots \ldots \ldots \ldots \ldots \ldots \ldots \ldots \ldots \ldots, 4-11$

D.2. Multilateral Sources $\ldots \ldots \ldots \ldots \ldots \ldots \ldots \ldots \ldots \ldots \ldots, 4,11$

D.3. In Country Sources $\ldots \ldots \ldots \ldots \ldots \ldots \ldots \ldots \ldots \ldots \ldots \ldots, 4-12$

E. Trade Finance $\ldots \ldots \ldots \ldots \ldots \ldots \ldots \ldots \ldots \ldots \ldots \ldots \ldots \ldots \ldots \ldots \ldots \ldots \ldots \ldots \ldots \ldots, 12$

E.1. U.S. Government Sources $\ldots \ldots \ldots \ldots \ldots \ldots \ldots \ldots \ldots \ldots \ldots, 4-12$

E.2. Multilateral Sources $\ldots \ldots \ldots \ldots \ldots \ldots \ldots \ldots \ldots \ldots \ldots \ldots \ldots, 4,13$

E.3. In Country Sources $\ldots \ldots \ldots \ldots \ldots \ldots \ldots \ldots \ldots \ldots \ldots \ldots \ldots \ldots \ldots \ldots, 4,14$

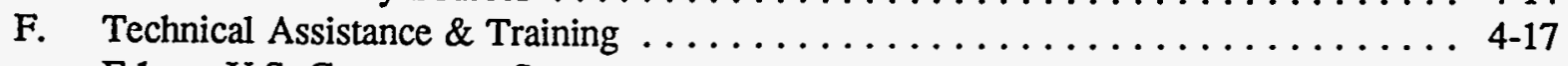

F.1. U.S. Government Sources $\ldots \ldots \ldots \ldots \ldots \ldots \ldots \ldots \ldots \ldots, 4-17$

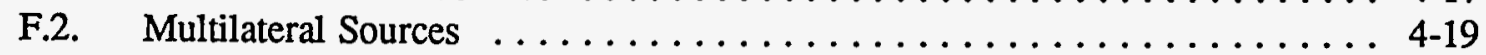

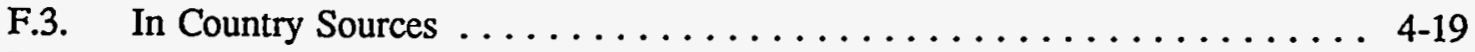

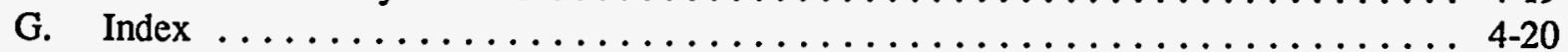

\section{PAKISTAN}

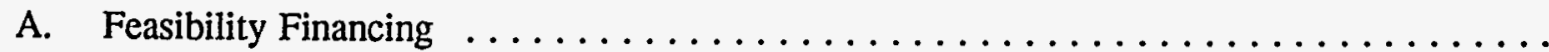

A.1. U.S. Government Sources

A.2. Multilateral Sources

A.3. In Country Sources

B. Project Finance - Private Sector.

B.1. U.S. Government Sources

B.2. Multilateral Sources

B.3. In Country Sources

C. Project Finance - Public Sector

C.1. U.S. Government Sources

C.2. Multilateral Sources

D. Cofinancing

D.1. U.S. Government Sources

D.2. Multilateral Sources

D.3. In Country Sources

E. Trade Finance

E.1. U.S. Government Sources

E.2. Multilateral Sources

E.3. In Country Sources

F. Technical Assistance \& Training

F.1. U.S. Government Sources

F.2. Multilateral Sources

F.3. In Country Sources

G. Index 


\section{RUSSIAN FEDERATION}




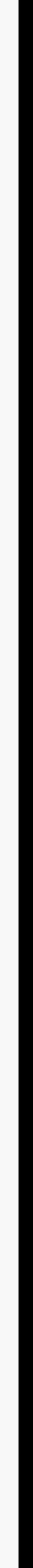




\section{A. FEASIBILITY FINANCING:}

\section{A.1. U.S. Government Sources}

\section{U.S. Trade and Development Agency (TDA)}

TDA is an independent, U.S. government agency that provides funding for feasibility studies, training programs, and seminars. TDA supports major projects in the public sector that offer large export or investment potential for U.S. companies. All proposed projects must have the host government's approval, meet the country's development priorities, create significant U.S. export potential, and offer untied financing options. TDA's participation usually ranges from $\$ 150,000$ to $\$ 750,000$.

Contact: Dan Stein, Regional Manager

Russia \& Newly Independent States

U.S. Trade and Development Agency

1621 North Kent Street

Arlington, VA 22209

Tel: $703 / 875-4357$

Fax: 703/875-4009

TDA also has trust fund accounts with multilateral institutions like the World Bank, International Finance Corporation (IFC), and European Bank for Reconstruction and Development (EBRD). This mechanism can be used to support feasibility studies that are tied to specific projects these institutions would likely support. In the case of the IFC, for example, project proposals must demonstrate that they are commercially viable and meet IFC investment threshold criteria as well as the funding requirements of TDA.

For IFC Trust Funds: Alakadri Bose

IFC

Tel: 202/473-0551

Fax: 202/676-1513

For EBRD Technical Cooperation Funds:

Dr. Ullrich Kiermayr

Tel: $44-71 / 338-6356$

Fax: 44-71/628-2530

At USTDA, Contact: Barbara Bradford

Tel: 703/875-4357

Fax: 703/875-4009

The International Fund for Renewable Energy and Energy Efficiency (IFREE)

Funded by the U.S. Agency for International Development, U.S. Department of Energy, the Rockefeller Foundation, and the U.S. Environmental Protection Agency, IFREE facilitates increased access to funding for renewable energy, energy efficiency, and, generally, environmentally-sound projects in developing countries, including the Russian Federation. Under the Prefeasibility Study Program, IFREE offers up to $\$ 50,000$ to support up to 50 percent of prefeasibility study costs, which enables project developers to secure project finance or additional funding for detailed project analyses required by private lenders and U.S. government agencies for the evaluation of projects. Energy efficiency and renewable energy, i.e., 
biomass, geothermal, small hydropower, natural gas, solar photovoltaic, solar thermal, or wind energy projects are considered. Projects must be commercially viable, identify sources of funding for the full feasibility study and in-country partners, and use predominantly U.S. equipment, materials, and services.

Contact: Patrick D'Addario

IFREE

777 North Capital Street, NE, Suite 805

Washington, DC 20002

Tel: 202/408-7916

Fax: 202/371-5116

Export-Import Bank's (EXIM) Engineering Multiplier Program

EXIM's Engineering Multiplier Program funds project-related feasibility studies and pre-construction design and engineering services. Under this program, EXIM offers fixed-rate loans and guarantees to foreign buyers of these services. This program is designed to generate additional overseas sales of U.S. goods and services since the foreign buyer is more likely to order U.S. equipment and services for a construction project on which U.S. engineers, designers, and architects performed the work. Up to $\$ 10$ million in the value of U.S. exports are covered. Projects supported under this program must generate subsequent U.S. export orders valued at no less than $\$ 10$ million or double the original export contract, whichever is greater. Direct loans are extended for up to 85 percent of the U.S. export value. The foreign buyer must match that with a 15 percent cash payment to the U.S. company. EXIM also offers guarantees for commercial financing for approved project-related local costs in the host country of up to 15 percent of the U.S. contract cost. If the project goes forward with U.S. goods and services, EXIM may extend a loan and/or guarantee, in which case the loan can then be rolled into the later financing.

Contact: John Wisniewski, Vice President

Engineering Division

Export-Import Bank of the United States

811 Vermont Avenue, NW, Room 1167

Washington, DC 20571

Tel: 202/565-3571

Fax: 202/565-3584

U.S. Agency for International Development (USAID) - Feasibility Support

USAID routinely supports feasibility studies in targeted sectors in the Newly Independent States (NIS) region, namely energy, environment, agribusiness, housing, private sector and financial sector development. Interested parties should track opportunities in the Commerce Business Daily.

Contact: Commerce Business Daily

Tel: $202 / 783-3238$

Fax: 202/512-2233

Committee on Renewable Energy Commerce and Trade (CORECT)

CORECT is an interagency working group comprised of representatives from 14 U.S. Federal government agencies, chaired by the U.S. Department of Energy. CORECT works closely with the U.S. Export Council for Renewable Energy (US/ECRE), an industry consortium of seven renewable energy trade associations, to promote renewable energy exports in international markets and ensure that renewable energy technologies and applications are integrated in development projects. 
Contact: Ronald Bowes, Director

Office of Technical Assistance

Energy Efficiency and Renewable Energy

U.S. Department of Energy

1000 Independence Avenue, SW, Room 5E-036

Washington, DC 20585

Tel: $202 / 586-2959$

Fax: 202/586-1605

Committee on Energy Efficiency Commerce and Trade (COEECT)

COEECT is an interagency working group comprised of representatives from 14 U.S. Federal government agencies, chaired by the U.S. Department of Energy. COEECT works closely with the Energy Efficiency Export Council to undertake market assessment for energy efficiency products and services, identify project financing from federal and multilateral institutions, and address the specific needs of the energy efficiency products and services industry.

Contact: Ronald Bowes, Director

Office of Technical Assistance

Energy Efficiency and Renewable Energy

U.S. Department of Energy

1000 Independence Avenue, SW, Room 5E-036

Washington, DC 20585

Tel: 202/586-2959

Fax: 202/586-1605

\section{A.2. Multilateral Sources}

European Bank for Reconstruction and Development (EBRD)

EBRD does perform pre-investment and/or feasibility studies usually for projects in which it is interested in investing. Interested parties should track the EBRD procurement notice bulletins. To obtain information on EBRD procurement opportunities, contact the representatives below.

Contact: Sara Shackelton, Commercial Specialist

Office of the U.S. Executive Director

One Exchange Square

London EC2A 2EH

England

Tel: $44-71 / 338-6569$

Fax: 44-71/338-6487

-or- 
Matt Handwork

Office of Multilateral Bank Operations

U.S. Department of Commerce

Washington, DC 20230

Tel: $202 / 482-3399$

Fax: 202/273-0927

\section{A.3. In Country Sources}

No known available sources.

\section{B. PROJECT FINANCE - PRIVATE SECTOR:}

\section{B.1. U.S. Government Sources}

\section{Overseas Private Investment Corporation (OPIC)}

This independent, U.S. government agency provides project financing, investment insurance, and a variety of investor services. In addition to the Russian Federation, OPIC is currently open for business in all countries in the NIS except Azerbaijan. OPIC has recently supplemented its finance products by supporting privately owned and managed equity investment funds. OPIC is currently supporting equity funds that will invest specifically in the Russian Federation and in environmental enterprises worldwide, including Russia.

\section{Project Financing:}

OPIC provides medium to long-term financing (over 3 years), available through loan guarantees and/or direct loans. Loan guarantees cover both commercial and political risks. OPIC has approximately $\$ 1$ billion available to finance projects in the NIS. OPIC offers direct loans for international investment projects, which range from $\$ 2$ to $\$ 200$ million. However, OPIC typically does not support projects under $\$ 10$ million. OPIC will participate in up to 50 percent of the total project cost for a new venture and up to 75 percent of the total cost of an expansion.

\section{Contact: John Harper, Regional Manager}

Russia \& Newly Independent States

Overseas Private Investment Corporation

1100 New York Avenue, NW

Washington, DC 20527

Tel: $202 / 336-8494$

Fax: 202/408-9866

Contact in Russia: . Eric Luhman (until 3/95) - or - Robert Feath (starting 4/95)

Tel: 7-502/224-1105 Fax: 7-502/224-1106 
The investment funds listed below have been capitalized primarily with funds from U.S. government and multilateral organizations:

\title{
CARESBAC (CARE Small Business Assistance Corporation)
}

This fund was capitalized through the support of the U.S. Department of Agriculture with $\$ 3.5$ million to invest in existing small- and medium-sized Russian companies. Companies with 15 to 100 employees, majority Russian ownership, and annual turnover from $\$ 150,000$ to $\$ 2$ million equivalent in rubles will be considered. Targeted sectors are the agro-food processing and distribution, light manufacturing, construction services, business services, and environmentally-sound industries. The Fund will take a minority equity position in companies and/or preferred stock and convertible debt. Only Russian entities may apply. Proposals should be sent to the Russian office.

\author{
Contact: Thomas C. Gibson \\ CARESBAC \\ 1401 New York Avenue, NW, Suite 1100 \\ Washington, DC 20005 \\ Tel: $202 / 737-8463$ \\ Fax: 202/737-5536 \\ -or- \\ Graham Humes, General Director \\ Lermontovsky Prospekt \#7, Second Floor \\ St. Petersburg 190008 Russia \\ Tel: 7-812/119-6336 \\ Fax: 7-812/119-6337
}

The Defense Enterprise Fund

The Defense Enterprise Fund was established as a non-profit corporation to promote private sector investment in restructuring the Russian defense industry. The Fund supports investments involving the personnel and/or facilities currently or formerly involved in research, development, production or operation, and conversion of large defense enterprises, which previously contributed to production of weapons of mass destruction. The Fund also makes investments in private sector spin-off initiatives from large defense enterprises and start-up initiatives by former defense or military personnel. This Fund will provide debt or equity support to enterprises that have privatized or that have already committed in writing to privatization. An enterprise is considered privatized if greater than 50 percent of ownership and control is held in the private sector.

Contact: Michael Lehner, Vice President/Investment Manager

Defense Enterprise Fund

104 Crofton Road

Waban, MA 02168

Tel: $617 / 527-3307$

Fax: 617/527-2722 
EBRD Small Business Fund

The objective of this $\$ 300$ million fund is to provide debt financing to micro and small business enterprises in Russia. The Fund is concentrating on providing loans but is looking to provide equity financing at a later date. There is no minimum loan amount, but generally will not exceed $\$ 75,000$. Equity financing, once in place, will be offered up to $\$ 200,000$. The Fund is currently lending to enterprises in the following cities: St. Petersburg, Toglitta, Tomsk, Tula, and Nizhny Novgorod. By June/July, 1995, the Fund will be operative in Moscow.

\section{Contact: Elizabeth Wallace \\ EBRD \\ One Exchange Square \\ London EC2A 2EH England}

Tel: $44-71 / 338-6169$

Fax: 44-71/338-7380

Environmental Enterprises Assistance Fund (EEAF)

EEAF invests in projects and companies in devcloping countries, including the Russian Federation. The main objective of EEAF is to catalyze the spread of renewable energy, energy efficiency, and other environmentally responsible technologies. EEAF provides direct loans and equity placements in environmentally-sound, commercially viable projects and capitalizes local investment funds. EEAF provides financial support for projects under $\$ 2$ million in renewable energy systems, energy efficient technologies, and environmentally responsible management of organic waste. Direct loans are made at concessional rates, but equity investments are expected to provide higher returns than conventional financing arrangements. On a limited, cost-reimbursable basis, EEAF may provide technical assistance for training and technical analysis of proposed projects. For project financing in Russia, EEAF works in conjunction with CARESBAC (see description of CARESBAC under Project Financing).

Contact: Brooks Browne, President

Environmental Enterprises Assistance Fund

1901 North Moore Street

Suite 1004

Arlington, VA 22209

Tel: 703/522-5928

Fax: 703/522-6450

\section{Far East Regional Venture Fund}

This is a $\$ 30$ million equity investment fund capitalized by the EBRD and managed by a consortium of investment firms led by Daiwa Securities and NIF Company. This fund invests in small- and mediumsized businesses in the Primorskii and Khabarovsk krais regions to facilitate the modernization, expansion and/or restructuring of privatized Russian enterprises. In addition to making equity investments, an additional $\$ 20$ million in funds will be available to provide technical assistance and prefeasibility support for investments made by the Fund. Investments ranges from $\$ 300,000$ to $\$ 3$ million. 
Contact: Martyn Nicholls

EBRD

One Exchange Square

London EC2A 2EH

England

Tel: $44-71 / 338-6269$

Fax: 44-71/338-6119

First NIS Regional Fund

The First NIS Regional Fund is a $\$ 160$ million close-ended investment fund managed by Baring Investment Management Ltd. The main objective of the Fund is to achieve long-term growth through equity and equity-related investments in NIS companies; those that are over-the-counter privatized corporations, joint stock companies, joint ventures, or partnerships. The primary sectors in which investments will be made will be natural resources-related companies, infrastructure, and telecommunications, which will represent 60 percent of the Fund's investments. The remaining 40 percent will be dedicated to light manufacturing, consumer products and services, and real estate. EBRD provided $\$ 20$ million in equity commitments, and $\$ 15$ million from the IFC. $\$ 20$ million for the debt portion of the Fund is expected from OPIC to cover loan guarantees.

The Fund bases their investment decisions upon the ability of NIS companies prospect for long-term growth: whether the company has foreign currency reserves or substantial export earning potential; human, technical, financial and/or other resources necessary to compete in the marketplace; substantial assets; international accounting standards; potential for long-term earnings and cash flow growth; and a sound business strategy. The Fund is managed by Baring Asset Management.

Contact: Richard Sobel, Director, Institutional Group

Baring Asset Management

155 Bishopsgate

London EC2M 3XY

England

Tel: 44-71/214-1871

Fax: 44-71/214-1635

\section{Fund for Large Enterprises in Russia (FLER)}

FLER was initially capitalized at $\$ 100$ million through grant support of USAID. Additional funds will be available through the Overseas Private Investment Corporation (OPIC), FLER's co-sponsor, and other U.S. government agencies such as the Export-Import Bank of the United States and the U.S. Trade and Development Agency. This fund offers financing packages, such as equity investments, loans, and technical assistance and training to medium- and large-scale enterprises in Russia. Enterprises, which are emerging from mass privatization programs, with 1,000 to 10,000 employees are considered. Investments will be made in (1) Russian start-up companies as well as those emerging from mass privatization; (2) joint ventures with U.S. and other companies to create commercially viable ventures that attract private sector capital; and (3) the development of efficient management techniques and corporate governance practices in Russian enterprises. FLER will invest between $\$ 1$ and $\$ 20$ million per project. 


\author{
Contact: Ilya Oshman, Vice President \\ Laura Hoffman, Director of Operations \\ FLER \\ 17 State Street \\ New York, NY 10004 \\ Tel: $212 / 668-8395$ \\ Fax: 212/668-0770 \\ -or- \\ Project Coordinator \\ Tsvetnoy Boulevard, 25-3 \\ 103051 Moscow \\ Russia \\ Tel: $7-095 / 929-9810$ or $44-81 / 913-3382$ \\ Fax: 7-095/929-9809
}

Global Environmental Emerging Markets Fund, L.P.

This fund is designed to take significant minority equity or equity-related positions in private companies in emerging markets in Africa, Asia, Latin America, and Eastern Europe. The Fund has raised $\$ 70$ million in capital through an offering of its securities to sophisticated investors, including financial institutions, in the U.S. and Europe. These securities will be partnership equity interests and OPIC-guaranteed longterm partnership notes, offered together or separately. The Fund will invest up to $\$ 10$ million in alternative energy, water treatment, air pollution control and waste management. Currently, the Fund is looking at a number of opportunities in the area of energy conservation and demand side management. The Global Environment Fund, L.P. manages this new fund and serves as its general partner. Projects are currently being sought for review and consideration.

Contact: H. Jeffrey Leonard, President Global Environmental Fund, L.P. 1250 24th Street, NW, Suite 600

Washington, DC 20037

Tel: 202/466-0529

Fax: 202/466-6454

\title{
New Europe East Investment Fund
}

Managed by Capital International, Inc., this $\$ 130$ million fund was launched in June 1993 with capital contributions by the EBRD, the International Financial Corporation (IFC), and pension funds. The Fund will make direct investments in privatized companies or newly established ventures in Central and Eastern Europe and the NIS that are managed by established Western industrial group. Investments range from $\$ 5$ - \$15 million. Up to a 20 percent stake is taken in each issuer's securities. 
Contact: Mr. Lam Nguyen-Phuong

Capital International, Inc.

25 Bedford Street

London WC2E 9HN

England

Tel: $44-71 / 257-6700$

Fax: 44-71/257-6767

\section{Russia Partners Fund}

This $\$ 155$ million fund will invest primarily in equity and equity-related instruments of privatized and privatizing companies, greenfield investments, and start-up ventures in the Russian Federation. The Fund will invest in hard-currency generating or export production businesses and sectors that offer high returns such as natural-resources, light manufacturing, telecommunications, distribution, and consumer products and services. The average size investment will range from $\$ 2$ to $\$ 15$ million. OPIC has fully guaranteed the Fund. Projects should demonstrate the ability to generate long-term revenue growth potential and high profit margins. The Fund may seek co-investment or other types of participation from Western partners. The local advisor to the Fund is International Economic Cooperation Company, a private Russian company. The Fund is managed by PaineWebber Inc., New York, through its asset management subsidiary Mitchell Hutchins Asset Management Inc.

\section{Contact: Drew Guff, Fund Manager \\ PaineWebber \\ 1285 Avenue of the Americas, 14th floor}

New York, NY 10019

Tel: $212 / 713-3214$

Fax: 212/713-1087

-or-

Lauralee Raddatz

Myasnitskaya Ulitsa, Dom 35

101959 Moscow

Russia

Tel: 7-095/207-9140

Fax: 7-095/975-2449

\section{Russia/NIS Major Projects Fund}

This fund will invest in equity and equity-related securities. OPIC will guarantee up to 75 percent of up to $\$ 300$ million. The Fund will concentrate on the telecommunications, energy, transportation, and metals processing sectors. Investments will range from $\$ 10$ to $\$ 20$ million. This fund is not as yet operational; it. is expected to be fully operational by the Summer, 1995 . 
Contact: Graham Williams, Managing Director

Overseas Private Investment Corporation

1100 New York Avenue, NW

Washington, DC 20527

Tel: $202 / 336-8479$

Fax: 202/408-9866

The Russian-American Enterprise Fund

The Russian-American Enterprise Fund was established in 1993 to stimulate the creation and expansion of small- and medium-sized businesses in the Russian Federation. Loans ranging from $\$ 500,000$ to $\$ 2$ million are offered directly or in conjunction with commercial banks acting as intermediary facilities. The Fund may also take equity positions or extend loans in promising small- and medium-sized enterprises (defined as firms with approximately 2,500 employees). Equity investment support is considered for wholly-owned indigenous projects, joint-ventures with U.S. partners and, to a lesser extent, subsidiaries of U.S. companies. The Fund may also support technical assistance and training related to actual or potential investments and loans. U.S. Agency for International Development initially capitalized the Fund at $\$ 340$ million for a three year period. The Fund is expected to raise additional capital from private and public sources.

Contact: Robert Towbin, President \& CEO

Russian-American Enterprise Fund

17 State Street, 33rd floor

New York, NY 10004

Tel: $212 / 483-1177$

Fax: 212/483-0999

Smolensk Regional Venture Fund

Managed by Siparex of France, this fund is capitalized with $\$ 12$ million from the EBRD. The Fund will make equity investments in medium-sized Russian enterprises (defined as enterprises with up to 1,000 employees) in the Smolensk oblast. The main objective of the Fund is to facilitate the modernization, expansion and/or restructuring of privatized Russian enterprises. The Fund will also provide technical assistance to support the investments it makes. Investments range from $\$ 300,000$ to $\$ 1.2$ million in all sectors, expect tobacco, armaments, and liquor industries.

Contact: Philippe Lambert

Siparex

139 , rue Vendome

69477 Lyon Cedex 06

France

Tel: $33-78 / 52-41-07$

Fax: 33-78/52-61-63

\section{St. Petersburg Regional Venture Fund}

Launched with a $\$ 30$ million capital contribution from the EBRD, this fund will make equity investments in small- and medium-sized Russian enterprises in the St. Petersburg and Leningrad oblasts. The main objective of the Fund is to facilitate the modernization, expansion and/or restructuring of privatized Russian enterprises. An additional $\$ 20$ million has been provided to support technical assistance and 
prefeasibility work in support of the investments made by the Fund. Investments range from $\$ 300,000$ to $\$ 3$ million in all sectors, expect tobacco, armaments, and liquor industries.

\section{Contact: Wolfgang Engler \\ Quadriga Capital Group \\ Hamburger Allee, 2-10 \\ Frankfurt am MAIN \\ Tel: $4969 / 7950-0023$ \\ Fax: $4969 / 7950-0060$ \\ -or-}

St. Petersburg Regional Venture Fund

Tel: $7-812 / 350-5622$

Fax: $7-812 / 213-4502$

Urals Regional Venture Fund

This is a $\$ 30$ million equity investment fund capitalized by the EBRD and managed by Fleming Investments Ltd. This fund invests in small- and medium-sized businesses in the Sverdlovsk, Perm, and Chelyabinsk oblast regions to facilitate the modemization, expansion and/or restructuring of privatized Russian enterprises. In addition to making equity investments, an additional $\$ 20$ million in funds will be available to provide technical assistance and prefeasibility support for investments made by the Fund. Investments ranges from $\$ 300,000$ to $\$ 3$ million.

Contact: George Horton

Fleming Investments Ltd.

25 Copthall Avenue

London EC2R 7DR

England

Tel: $44-71 / 638-5858$

Fax: 44-71/382-8155

The investment funds listed below have been capitalized primarily with funds from private sources:

Brunswick Fund

Launched in October, 1993, this $\$ 10$ million fund invests in small- and medium-sized Russian companies primarily in the oil and gas, utility, mineral extraction and processing and shipping (ocean fishing fleets) sectors. Investments range from $\$ 200,000$ to $\$ 600,000$.

Contact: Martin Andersson, Manager

25/3, Tsvetnoy Boulevard

Moscow 103051

Russia

Tel: 7-095/291-6358

Satellite Tel: 7-501/929-9800

Satellite Fax: 7-501/929-9801 


\section{First Russian Frontiers Trust PLC}

Managed by Pictet Asset Management, this fund is capitalized approximately at $\$ 60$ million. The Fund will invest in a diversified portfolio of securities of countries in the NIS and Central and Eastern Europe regions. Initially, Russia, Ukraine, Uzbekistan, Bulgaria, and Romania will be the focus of the Fund. 15 percent of the Fund's portfolio will be invested in the more developed markets in Central and Eastern Europe.

Contact: Douglas Polunin, Senior Investment Manager

5 Devonshire Square

EC2M 4LD London

England

Tel: $44-71 / 972-6800$

Fax: 44-71/972-6876

\section{The Fleming Russia Securities Fund, Ltd.}

This $\$ 54$ million close-ended fund invests in shares of Russian companies that are active in the oil and gas telecommunications, utilities, mining, and automotive sectors. The Fund will also invest in debt securities. As the Fund's objective is to maintain a high percentage of liquidity, the Fund will not support any portfolio investment that exceeds 20 percent of the Fund's total assets.

Contact: Stephanie Bishop

Fleming Investments Ltd.

25 Copthall Avenue

London EC2R 7DR

England

Tel: 44-71/638-5858

Fax: 44-71/374-0263

\section{Framlington Russian Investment Fund}

This is a close-ended investment fund capitalized at $\$ 66$ million that invests in small- to medium-sized Russian companies in the energy, forestry/paper, real estate, communications, tourism, advanced technology, food processing, and retail sectors. The Fund usually takes minority positions in companies of 20 percent and invests in the range of $\$ 500,000$ to $\$ 4$ million. Shareholders include the EBRD, IFC, U.S. pension, hedge, and mutual funds.

\section{Contact: Gary Fizgerald, Managing Director \\ 155 Bishopsgate \\ London EC2M 3XJ \\ England \\ Tel: $44-71 / 374-4100$}

Fax: $44-71 / 330-6642$

Junction Investors Ltd. (JIL)

This venture capital fund is capitalized at $\$ 50$ million by private sources. The Fund provides equity investments and arranges for debt and/or additional equity funding for small- and medium-sized businesses that demonstrate the potential for long-term growth and infrastructure development. Investments range from $\$ 1$ to $\$ 5$ million. 
Contact: Thomas R. DiBenedetto, President

Junction Investors Ltd.

84 State Street, 2nd Floor

Boston, MA 02109

Tel: $617 / 248-9600$

Fax: 617/248-9652

\section{NCH Advisors}

This group was launched with $\$ 160$ million of capital from large institutional investors and U.S. and European investment managers in 1993. This group provides equity in existing businesses, start-up capital, joint venture financing, short- and medium-term financing, real estate financing and the purchase of government and commercial obligations. Natural resources, telecommunications, banking, real estate, agrobusiness, pharmaceutical, and high technology are targeted sectors for investment.

Contact: Alexander Papachristou

NCH Advisors

635 Madison Avenue, 4th Floor

New York, NY 10022

Tel: $212 / 308-4343$

Fax: 212/308-4398

New Russian Small Business Investment Fund

This facility will provide debt financing through selected Russian banks for small Russian enterprises. There is no strict definition of what constitutes a small enterprise, but companies capitalized over $\$ 4$ to $\$ 5$ million do not qualify. Between $\$ 50,000$ and $\$ 200,000$ will be invested in each project. Loans are granted directly from Russian banks to Russian enterprises.

The Fund is currently capitalized at approximately $\$ 4$ million through the sale of agricultural commodities provided by the U.S. Department of Agriculture. The source of funding is from USAID and is an integral part of its small business development activities in Russia.

Contact: Jack Heller, President

New Russian Small Business Investment Fund

1200 New Hampshire Avenue, NW

Suite 230

Washington, DC 20036-6804

Tel: $202 / 466-4700$

Fax: 202/223-4826

\section{Newstar Fund}

This fund is a small venture capital and merchant bank operation capitalized at approximately $\$ 20$ million. Newstar invests in equity in private, small- to medium-sized undervalued companies that are that are export oriented with a strong management and solid cash flow potential. Projects must involve a Western partner. The Fund is interested in supporting investments in the range of $\$ 500,000$ to $\$ 5$ million. 
Contact: Brad Wegner, Manager of Investment

Newstar, Inc.

1001 Pennsylvania Avenue, NW, Suite 480-North

Washington, DC 20004

Tel: $202 / 783-4155$

Fax: 202/628-5986

-or-

Jeffrey Hammer, Director of Investments

Vspolni Pereulok, 19/20

103001 Moscow, Russia

Tel: 7-095/291-8338/8341

Fax: 7-095/291-2926

Satellite Fax: 7-502/221-1470

Pioneer Fund

This fund expects to raise $\$ 100$ million by the end of 1995 to support long-term projects in Russia with export potential. The Pioneer Group has a similar fund for Poland, which was launched with only $\$ 100,000$ seed capital and now has $\$ 1$ billion portfolio of Polish equities and government bonds.

Contact: Susan Shepard, Assistant to President

The Pioneer Group

60 State Street

Boston, MA 02109

Tel: $617 / 742-7825$

Fax: 617/422-4286

Red Tiger Investment Co. Ltd.

This $\$ 15$ million open-ended fund invests in publicly traded company stock on the Moscow and St. Petersburg exchanges, joint ventures, and in pre-IPO investments (companies before the time of the "initial public offering"). The Fund aims to invest in a diversified portfolio of Russian entities.

Contact: Sophia Shaw or Philip Franklin,

Aldermary House 10-15 Queen Street

London EC4N 1TX

England

Tel: $44-71 / 332-0360$

Fax: 44-71/332-0341

Russia and the Republics Equity Partners LP (RARE)

This small venture capital fund invests in small- to medium-sized start-up businesses or new joint venture operations that demonstrate strong short-term profitability and long-term growth potential. The Fund supports investments in the range of $\$ 1$ to $\$ 5$ million. The Fund is currently capitalized at $\$ 25$ million. 
Contact: Herbert Denton, Partner

Providence Capital, Inc.

730 5th Avenue

New York, NY 10019

Tel: $212 / 888-3200$

Fax: 212/888/3203

-or-

Joseph Condon, Chairman

Kamergersky Pereulok, \#5

Moscow, Russia

Tel: 7-095/247-9051

Fax: 7-095/229-1327

Russia Technology Fund

This fund is in the process of raising capital. It is anticipated that the Fund will be capitalized at $\$ 15-\$ 20$ million. The Fund will be managed by Top Technology, Ltd.

Contact: Harry Fitzgibons

Top Technology Ltd.

20-21 Tooks Court

London EC4A 1LB

England

Tel: $44-71 / 242-9900$

Fax: 44-71/405-2863

Russia Value Fund, L.P.

Launched in September, 1994, this $\$ 50$ million fund invests in publicly traded shares of Russian companies and other capital market instruments, including sovereign debt. The oil and natural gas, electrical generation and distribution, telecommunications, and construction sectors are being targeted for investment. The minimum initial investments are $\$ 100,000$ and provides quarterly redemptions.

\section{Contact: Claudia Diaz}

San Antonio Capital Management Co.

P.O. Box 690327

San Antonio, TX 78269-0327

Tel: $210 / 694-4400$

Fax: 210/561-3316

Russian Sector Development Corporation

This $\$ 50$ million fund provides equity and debt financing, investment banking services, seed capital, and cofinancing services with major Western and Russian institutional investors. Investments range from $\$ 5$ to $\$ 50$ million and will focus on the Far East region of the Russian Federation. 
Contact: Natalya Romanova or Evgeny Okun, Managing Directors

Sovcap, Inc.

Leninsky Prospekt 13, Suite 122

117071 Moscow

Russia

Tel: $7-095 / 237-4680$ or $237-9009$

Fax: 7-095/237-9009

\section{Russian Venture Capital Fund of America}

Managed by Palms \& Co., Inc., this fund was capitalized with $\$ 100$ million of funds from private and institutional investors. The Fund will co-invest with other private or quasi-governmental funds in projects that involve major participation from Western investors. The Fund seeks a diversified portfolio of investments and does not target particular sectors for investment. To enable Western companies to reach the required threshold of necessary funding or capital, the Fund, in certain cases, will provide the required level of co-investment needed by institutional investors and government agencies.

Contact: Peter Van de Waal

515 Lake Street South

Kirkland, WA 98033

Tel: $206 / 828-6774$

Fax: 206/827-5528

\section{B.2. Multilateral Sources}

\section{European Bank for Reconstruction and Development (EBRD)}

EBRD provides loans, equity investments, debt guarantees, debt and equity underwriting, advice, and technical cooperation to promote private and entrepreneurial initiatives and foster transition toward democratic, market-oriented economies in the CEE and NIS regions. The Bank does not issue guarantees for export credits or undertake insurance activities. The Bank's operations are structured along geographic lines: Northern and Southem tier country teams headed by two vice presidents that report directly to EBRD President Jacques de Larosière. The Russia country team falls under the Northern Tier Vice Presidency. Each country team brings together merchant and development banking operations, sectoral expertise (i.e., natural resources and tourism, power and energy utilities) and cross-support functions (i.e., environmental appraisals, procurement, syndication) for each country team.

The mandate of the EBRD requires that 60 percent of its loans be directed to funding private enterprises and privatization efforts. These loans are more risky than World Bank loans, which carry sovereign guarantees. The balance of its funding is directed to physical and financial infrastructure or development projects. EBRD will only finance projects that benefit the country in which they are located. Although U.S. companies may approach the Bank with specific project proposals, host government support is looked upon favorably. 


\begin{tabular}{|c|c|c|}
\hline Contact for Russia: & $\begin{array}{l}\text { Guy de Sellis } \\
\text { Russia Country Team } \\
\text { EBRD } \\
\text { One Exchange Square } \\
\text { London EC2A 2EH } \\
\text { England } \\
\text { Tel: } 44-71 / 338-6662 \\
\text { Fax: } 44-71 / 338-7470\end{array}$ & $\begin{array}{l}\text { Lou Naumovski } \\
\text { Deputy Representative } \\
\text { EBRD } \\
8 / 10 \text { Gasheka Street } \\
\text { 125047 Moscow } \\
\text { Russia } \\
\text { Tel: } 7-503 / 956-1111 \\
\text { Fax: 7-503/956-1122 }\end{array}$ \\
\hline Contact for Energy: & $\begin{array}{l}\text { Martin Blaiklock, Team Leader } \\
\text { Power/Energy - Northem Tier } \\
\text { EBRD } \\
\text { One Exchange Square } \\
\text { London EC2A 2EH } \\
\text { England } \\
\text { Tel: 44-71/338-6663 } \\
\text { Fax: } 44-71 / 338-7280\end{array}$ & $\begin{array}{l}\text { Ananda Covindassamy } \\
\text { Power/Energy - } \\
\text { Southem Tier } \\
\text { EBRD } \\
\text { One Exchange Square } \\
\text { London EC2A 2EH } \\
\text { England } \\
\text { Tel: 44-71/338-6872 } \\
\text { Fax: 44-71/338-7280 }\end{array}$ \\
\hline
\end{tabular}

International Finance Corporation (IFC)

IFC, a member of the World Bank, is the largest source of direct financing for private sector projects in developing countries, including the Russian Federation. Unlike the World Bank, IFC lends directly to private companies and does not request guarantees from host-country governments. It can provide loans, make equity investments in private businesses, and mobilize additional loan and equity financing in international financial markets through syndication efforts. Although IFC invests and lends on market terms, it finances projects unable to obtain sufficient funding on reasonable terms from other sources. Increasingly, the IFC is working through intermediary financial facilities in order to support smaller scale projects and supporting cofinance arrangements with the World Bank (GEF) and EBRD.

Loans and equity investments are usually limited to no more than 25 percent of project cost. IFC's minimum investment project support is $\$ 10$ million. Funds may be used for foreign or local expenditures related to overall project costs, i.e, fixed assets, permanent working capital, interest during construction, and pre-operating cost. IFC can invest up to 35 percent of the share capital as long as it is not the major shareholder. It turns over its equity often by sale to local investors when the investment has matured. Both fixed and variable rate loans are offered; rates are determined on a commercial basis. Terms normally run from seven to twelve years.

\section{Contact for Russia: Anthony Doran, Manager}

Europe Department

International Finance Corporation

1850 I (Eye) Street, NW, Room I-9151

Washington, DC 20433

Tel: 202/473-3929

Fax: 202/676-9593 
Contact for Energy \& Environment: Martyn Riddle, Manager

Environmental Unit

International Finance Corporation

1850 Eye Street, NW

Washington, DC 20433

Tel: 202/473-0661

Fax: 202/676-9495

\section{B.3. In Country Sources}

No known available sources

\section{PROJECT FINANCE - PUBLIC SECTOR:}

\section{C.1. U.S. Government Sources}

NIS Industrial Partnering Program

The 1994 Foreign Operations Appropriations Act provided for a $\$ 35$ million NIS Industrial Partnering Program. The $\$ 35$ million effort is designed to promote partnerships involving US industry, universities, DOE National Laboratories and key institutes of the NIS. The main objective of this program is to assist NIS institutes with converting from defense to commercial applications and to prevent and reduce proliferation of weapons of mass destruction. As a general guideline, these funds will be allocated according to the following percentages: 80 percent Russian Federation, 10 percent Ukraine, 5 percent Belarus, and 5 percent Kazakhstan. This effort is managed by the Department of Energy (DOE).

This program consists of three components: $\$ 20$ million for stabilization, $\$ 12$ million for cost-shared industrial partnering, and $\$ 3$ million for academic support.

The stabilization component provides $\$ 20$ million of funding to NIS institutes and DOE national laboratories to commercialize appropriate technologies. This program builds on existing linkages and prior collaboration among NIS institutes and DOE national laboratories. Project proposals are reviewed by an Inter-Laboratory Board and by DOE and the U.S. Department of State. The Inter-Laboratory Board will attempt to incorporate all project proposals into a comprehensive, unified program of scientific cooperation.

The $\$ 12$ million component for cost-shared industrial partnering is designed to promote the commercialization of technologies developed for the NIS weapon programs. An industrial consortium, US Industry Coalition (USIC), will be formed to develop and commercialize projects on a cost-shared basis with the laboratories. The $\$ 12$ million will be held in an escrow account for the purposes of developing projects. To supplement these funds, industry members are expected to contribute matching funds equivalent to approximately $\$ 8$ million in 1994 . The goal of this program is to establish the framework and successful commercialization so that US companies can provide approximately $\$ 30$ million/year to initiate and renew partnerships with NIS weapon's institutes without US government assistance. 
The remaining $\$ 3$ million will provide funding for a consortium of academic institutions led by the University of New Mexico to develop a telecommunications network, provide management and business training support to the NIS institutes and USIC.

Contact: $\quad$ Michael Deegan, President

United States Industry Coalition

901 University Blvd., SE

Albuquerque, NM 87106-4339

Tel: $505 / 272-7344$

Fax: 505/272-7355

\section{Export-Import Bank's Project Finance Program}

EXIM Bank recently launched a new program to finance projects that are dependent solely on the project cash flow of the particular project for repayment. Projects under this program can not rely on sovereign guarantees to assure repayment as is normally required under typical EXIM Bank export credit packages. Under this program, EXIM offers (1) allowance of up to 15 percent foreign content in the US package; (2) financing of interest accrued during construction related to the EXIM Bank financing facilities; (3) financing of host country local costs of up to 15 percent of the US contract value; (4) maximum repayment term allowed under the OECD guidelines; (5) no minimum/maximum limitations on project size; (6) flexible coverage and equity arrangements; (7) exposure fee commensurate with risk; and (8) rapid application processing.

Contact: Dianne Rudo, Vice President

Project Finance Division

Export-Import Bank of the United States

811 Vermont Avenue, NW

Washington, DC 20571

Tel: $202 / 565-3690$

Fax: 202/565-3695

\section{C.2. Multilateral Sources}

International Bank for Reconstruction and Development (WORLD BANK)

The World Bank, a multilateral lending agency, is the largest source of financial and technical assistance to the public sector in developing countries. The Bank also makes policy-oriented structural and sectoral adjustment loans to support market-oriented institutional reforms. The Bank lends to member governments for public sector, development projects, not to the private sector. The Bank affiliate that lends to the private sector is the IFC. Loans are made only to governments or to agencies that can obtain a government guarantee for repayment. Bank funds are used by member govemments to import food and equipment, fund project construction, and obtain consultant services. Interest rates on Bank loans are set a half a percentage point above the Bank's average cost of borrowing and repayment terms are normally twelve to fifteen years, including a three to five year grace period.

The Bank is particularly active in the energy sector, mostly in oil and gas-related projects. However, there is increased interest in supporting energy efficiency and conservation projects, especially in the CEE and NIS regions. 
Contact for Russia: Yukon Huang, Director

Europe \& Central Asia Department

World Bank, Room H3-051

Washington, DC 20433

Tel: 202/473-5357

Fax:202/477-3274

Contact for Energy: Jonathan Brown, Division Chief

Infrastructure, Energy \& Environment Division

World Bank, Room H3-139

Washington, DC 20433

Tel: 202/473-2469

Fax:202/477-3285

Russian Energy Savings Fund (RESF)

Under a loan package for gas distribution from the World Bank through the Russian Ministry of Finance, a Russian Energy Savings Fund is in the process of being established to support energy efficiency investments in several pre-approved cities in the Russian Federation.

Contact: $\quad$ Valery Vasiliev, Vice President of RESF

Deputy Head, Energy Efficiency \& Renewable Energy

Ministry of Fuels and Energy

Tel: 7-095/206-6912

Fax: 7-095/975-2045

Nuclear Safety Account

An outgrowth of the G-7 Munich Summit of 6-8 July, 1992, the Nuclear Safety Account was set up by the EBRD to receive contributions totalling ECU 115 million (approximately $\$ 150$ million) by donor countries for grants to support nuclear safety projects in countries in the CEE and NIS regions. The main objective of the Account is to finance, through grants, projects designed to implement immediate operational safety and technical safety improvement measures for nuclear reactors in the CEE and NIS regions. Priority will be given to those reactors that present a high level of risk which can be significantly reduced by short-term and cost-effective safety improvements, and to those reactors that are necessary to ensure the continuity of national electricity supply in the region. The majority of the projects, therefore, will address security problems in existing REMK and VVER-230 reactors. Since donors are supporting efforts to undertake feasibility studies and technical assistance to address these problems, the Account will focus on providing the necessary funds to purchase equipment.

Contact: Francois Demarcq, Director

Nuclear Safety Account

EBRD

One Exchange Square

London EC2A 2EH

England

Tel: 44-71/338-6792

Fax: 44-71/338-6109 


\section{Global Environment Facility (GEF)}

Established in 1990, GEF provides grants for investment projects and technical assistance to assist developing countries to address four main global (transboundary) environmental problems: global warming, pollution of international waters, destruction of biological diversity, and depletion of the ozone layer. GEF is co-managed by the World Bank, U.N. Development Programme, and the U.N. Environmental Programme. To qualify for funding under the GEF, projects must be innovative, demonstrate the effectiveness of a particular technology or approach, and fall into one of the four priority areas. GEF funding is possible if the project offers substantial global benefits, but is unlikely to be viable without some concessional funding or if a project is economically viable but requires supplemental finance to bring about global benefits.

GEF projects can either be free-standing, components of World Bank projects, or pass through the IFC to support private sector ventures that have both important demonstration benefits and host government endorsement. Free-standing GEF projects are limited to $\$ 10$ million, and GEF components of World Bank projects must not exceed $\$ 30$ million. GEF funds can leverage regular Bank projects by paying the additional cost of incorporating environmentally benign technologics in Bank-supported projects. GEF funds would cover the difference in cost between what the host country is willing to pay and the cost of the benign technology. Use of GEF funds through the IFC can be used if the sponsor/lender could not otherwise underwrite the risk under prevailing market conditions; funds cannot be used to avert normal commercial risks.

Contact: Mr. Ken Newcombe, GEF Coordinator

World Bank, Room S2-141

Environment Division

Washington, DC 20433

Tel: $202 / 473-6010$

Fax: 202/522-3256
Ms. Jocelyn Albert

GEF Regional Coordinator

European Community \& Middle East

World Bank

Washington, DC 20433

Tel: 202/473-3458

Fax: 202/522-3256

\section{C.3. In Country Sources}

No known available sources

\section{COFINANCING}

\section{D.1. U.S. Government Sources}

Not applicable.

\section{D.2. Multilateral Sources}

International Bank for Reconstruction and Development (World Bank)

Although the Bank mainly lends to governments and government agencies, it can also provide guarantees to commercial lenders for public and private sector projects. The Bank's guarantee program currently covers loans totalling $\$ 1$ billion. As a way to attract private sector capital and encourage direct foreign 
investments in developing countries, the Bank's Executive Directors approved a proposal making guarantees a mainstream instrument of Bank opcrations in September 1994. There are two types of guarantees offered: (1) partial risk guarantee that covers nonperformance of sovereign contractual obligations or other contractual nonperformance problems in a project and (2) partial credit guarantee which extends maturities beyond what private lenders could otherwise provide.

By covering risks that the market would not bear, the Bank's guarantee program helps reduce the cost of financing projects by guaranteeing against contractual nonperformance, offers flexibility to structure project financing by extending maturities, and attracts private sources of capital by sharing risks of undertaking infrastructure projects in developing countries.

Contact: Nina Shapiro, Manager

Project Finance Group

Cofinancing and Financial Advisory Department

World Bank

Tel: $202 / 473-1650$

Fax: 202/477-0218

European Bank for Reconstruction and Development (EBRD)

The EBRD utilizes both private and official cofinancing techniques to supplement its own capital in support of private and public sector projects.

In addition to providing direct loans to facilitate the financing of public sector projects, the EBRD jointly finances or cofinances on a parallel basis with other multilateral banks or organizations, bilateral financial institutions or development assistance agencies, and Export Credit Agencies (ECAs). The EBRD has developed a cofinancing technique with ECAs called "Export Credit Loan Arrangement Technique (ECLAT)." ECLAT permits the EBRD to tap into additional sources of funds for procurement of equipment and provides a vehicle to insure transactions between the commercial bank and the borrower. ECLAT allows for open procurement opportunities and establishes a direct lending relationship between commercial banks and its borrowers that would not be possible under conventional financing arrangements.

To mobilize additional sources of funds for private sector projects, the EBRD participates in loan syndications with other commercial banks; in this way, commercial banks can benefit from the EBRD's preferred creditor status, its knowledge of specific countries, and financial expertise.

Contact: Noreen Doyle, Director

Credit and Syndications/External Financing

EBRD

One Exchange Square

London EC2A 2EH

England

Tel: 44-71/338-6196

Fax: 44-71/338-6108

International Finance Corporation (IFC)

The IFC syndicates participations in loans and provides parallel and joint financing as a way to enable commercial banks to take on the risks of lending to developing countries and its clients access additional 
, financing sources from international capital markets, and to raise long-term finance on reasonable terms on behalf of its clients.

Contact: Richard Parry

Syndications Department

IFC

Tel: $202 / 473-0398$

Fax: 202/334-8713

\section{D.3. In Country Sources}

Not applicable.

\section{E. TRADE FINANCE:}

\section{E.1. U.S. Government Sources}

\section{Export-Import Bank of the United States (EXIM)}

EXIM is an independent, U.S. government agency that provides support for U.S. exports through shortand medium-term export credit insurance, medium- and long-term loan guarantees, medium- and long-term direct and intermediary loans, working capital guarantees, and project financing. On April 1, 1992, the Stevenson and Byrd amendments were repealed, removing both the $\$ 300$ million cap on total EXIM authorizations to support U.S. exports to the NIS and restrictions on fossil fuel transactions. EXIM does finance energy efficiency and renewable energy projects that incorporate geothermal, solar, wind, hydroelectric, cogeneration and biomass technologies.

EXIM will only help finance exports of U.S. goods and services containing at least 50 percent U.S. content. The entire value of the shipment is covered under short-term export credit programs, while 100 percent of the U.S. content of the shipment is covered under medium- and long-term programs provided that EXIM's support does not exceed 85 percent of the export price. EXIM's short-term programs cover up to 360 days, medium-term programs cover up to five years, and long-term programs cover twelve years. EXIM is only open for short- and medium-term lending in Russia.

In Russia, EXIM offers four main programs:

\section{Sovereign Risk:}

Currently, EXIM offers short-term export credit insurance and medium-term loans for the Russian Federation. For transactions involving state-owned or quasi-public entities, EXIM has arrangements with the Bank for Foreign Trade of the Russian Federation (Rosvneshtorgbank/VTB) and the Bank for Foreign Economic Affairs (Vnesheconombank/VEB). VTB and VEB act as sovereign guarantors on behalf of the Russian government and, as such, carry the full faith and credit of the Russian Federation. EXIM requires clearance from the Ministry of Finance (MOF) and either VEB or VTB for projects that may involve sovereign risk before processing applications for financing. 
Contact: Ministry of Finance

Mikhail Kasyanov

Tel: 7-095/298-9161

Fax: 7-095/925-0889

VEB

Alexander Zhitnik or Ludmila Rybakova

Tel: 7-095/204-6384

Fax: 7-095/975-2069

VTB

Ms. Tatjana Pavlova Tel: 7-095/928-4638

Mr. Vladimir Litvinenko Tel: 7-095/204-6840

Mr. Andrei Shipilov Tel: 7-095/204-6552

New York Office of VEB and VTB

Mr. Oleg Enoukov

Tel: $212 / 421-8660$

Fax: 212/421-8677

Credit Guarantee Facility:

EXIM will only consider Russian commercial bank risk on an exceptional basis. For private sector transactions, EXIM has a $\$ 15$ million credit guarantee facility for medium-term financing with Tokobank, a Russian private commercial bank, extended through the Bank of New York.

Contact: Mr. Oleg Baguirov

Tokobank

Tel: 7-095/204-7003

Fax: 7-503/956-3138

Ms. Natasha Gurfinkel

Bank of New York

Tel: $212 / 635-8130$

Fax: 212/635-8936

\section{Limited Recourse Project Finance:}

Under the Project Incentive Agreement, EXIM offers project financing whereby EXIM finances Russian purchases of U.S. goods and services for new projects, namely energy projects. No sovereign or private commercial guarantees are required. Projects will be evaluated on the basis of their commercial viability and ability to generate hard currency revenues to cover repayment. Repayment terms and security arrangements will be-determined on a case-by-case basis. Public sector projects may require a waiver of the World Bank's negative pledge clause.

\section{Export Contract Security:}

EXIM signed an Oil and Gas Framework Agreement in July 1993 under which $\$ 2$ billion of financing for purchases of equipment and services to rehabilitate existing Russian oil and gas production facilities. EXIM will be secured from hard currency sales of oil or related products. Repayment terms will be five 
years or longer and the minimum amount of financing will be $\$ 25$ million. Energy efficiency and conservation projects will be considered as long as they can generate hard currency revenues and meet EXIM requirements, such as U.S. content requirements. The terms of the loans will be determined on a case-by-case basis. All other terms and conditions will be set in accordance with EXIM's procedures.

EXIM signed a Memorandum of Understanding with GAZPROM in November 1994 that allows EXIM to support $\$ 750$ million in U.S. equipment and services to GAZPROM for rehabilitation of Russia's natural gas sector. EXIM will be secured through the hard currency export sales by GAZPROM.

Contact: Dmitry Ermolov

GAZPROM

Tel: 7-095/163-1184

Fax: 7-095/164-4645

Contact for Russia: Tom Moran, Vice President

Europe \& Canada Division

EXIM

811 Vermont Avenue, NW

Washington, DC 20571

Tel: 202/565-3801

Fax: 202/565-3816
Danielle Montgomery

Loan Officer, Russia \& NIS

EXIM

811 Vermont Avenue, NW

Washington, DC 20571

Tel: 202/565-3813

Fax:202/565-3816

For General Michelle Roling

Inquiries, Contact: International Business Development

Tel: 202/565-3900

Fax: 202/565-3931

Russian Commodity Import Program (CIP)

CIP is a $\$ 90$ million grant program to the Russian Government to help Russian entities finance imports of U.S. equipment and technology that improve the efficiency of energy use and environmental quality. This program targets the natural gas transmission, distribution and use; oil production; district heating systems; power generation, transmission, and use; environmental protection agencies; and coal mining sectors. The main purpose of the program is to offer equipment at attractive, no-cost, or cost-sharing terms to beneficiary Russian commercial enterprises and public-sector or quasi-private agencies. Funds are to be allocated where there is reasonable assurance that the importer will be able to pay a share of the value of the commodities to be imported. Russian entities targeted for CIP assistance have already been selected. Although Russian entities have already been selected to receive CIP grants, opportunities exist to procure equipment to fulfill grants to these Russian enterprises. Procurement notices will be published in Commerce Business Daily or procurement notices may be obtained directly from USAID's Office of Procurement. USAID honors fax requests only.

Contact: Office of Procurement

USAID

Fax: 703/875-1957 


\section{U.S. Small Business Administration (SBA)}

SBA provides financial and business development assistance to assist small businesses in developing export markets. SBA offers the following programs: Regular Business Loan Program, Export Revolving Line of Credit Program, and the International Trade Loan Program. All these programs require the participation of an eligible commercial bank since they provide guarantees for loans.

Contact: U.S. Small Business Administration

Tel: 800/U-ASK-SBA

Fax: 202/205-7064

\section{$\underline{\text { U.S. Commercial Banks }}$}

Listed below are a sampling of U.S. commercial banks that are active in Russia some of which have offices in Moscow:

Bank of America

David Rees, Vice President \& Representative

World Trade Center, Office 1605

Krasnopresnenskaya NAB 12

Moscow Russia

Tel: 7-095/253-7054

Satellite Tel: 7-502/253-1910

Fax: 7-095/253-9565

Satellite Fax: 7-502-253-1910

-or-

Shahzad Shahbaz, Regional Manager

1 Alie Street

London E1 8DE

England

Tel: 44-71/634-4876

Fax: 44-71/634-4690

Chase Manhattan Bank

Sergei Boboshko

World Trade Center

Krasnopresnenskaya NAB 12

Moscow 123610

Russia

Tel: 7-095/253-2865

Satellite Tel: 7-502/253-9565

Fax: 7-095/230-217

-or- 
Christopher Piparo

4 Chase MetroTech, 20th Floor

Brooklyn, NY 11245

Tel: 718/242-1391 Fax: 718/242-4267

Chemical Banking Corporation

Kerry Annett, Vice President

270 Park Avenue, 17th Floor

New York, NY 10017

Tel: $212 / 270-3388$

Fax: 212/270-4379

Citibank

Stephen Reece

Gacheka Street, Bld. 8

Moscow

Tel: 7-095/956-2345

Satellite Fax: 7-503/956-2345

Satellite Fax: 7-503/251-4991

Credit Suisse-First Boston

John Zuckerman

Belinsky Street, 5

Moscow 103009

Russia

Satellite Tel: 7-502/225-8768

Satellite Fax: 7-502/225-8799

West Merchant Bank Limited

Michael Dunne, Managing Director for Project \& Export Finance

33-36 Gracechurch Street

London EC3V OAX

England

Tel: $44-71 / 220-8713$

Fax: 44-71/626-4270

\section{E.2. Multilateral Sources}

No known available sources.

\section{E.3. In Country Sources}

Rosvneshtorgbank (VTB) - Russian Bank for Foreign Trade

For its corporate clients, this Bank offers both hard currency and ruble accounts, correspondent banking services domestically and internationally, and other trade support services. 
Contact: Yuri Poletaev, Chairman

Rosvneshtorgbank

Kuznetsky Most 16

Moscow 103031

Russia

Tel: 7-095/204-6442

Fax: 7-502/956-3727

Vnesheconombank (VEB) - Bank for Foreign Economic Affairs

9, Academika Sakharov Prospect

Moscow 107078

Russia

Tel: 7-095/204-6519

Fax: 7-095/975-2104

-or-

New York Representation

Tel: 212/421-8660

Fax:212/421-8677

International Moscow Bank

5/6 Pushkinskaya Street

Moscow 103009

Russia

Tel: 7-095/292-9632

Fax: 7-095/975-2214

Moscow Import-Export Bank

5/3 Ananiewsky Per.

Moscow 103045

Russia

Tel: 7-095/208-4445

Fax: 7-095/207-7518

Inkombank

14 Nametkina Street, block 1

Moscow 117420

Russia

Tel: 7-095/332-0699

Fax: 7-095/331-8833 
Mosbusinessbank (Moscow Bank for Business Promotion)

15, Kuznetsky Most

Moscow 103780

Russia

Tel: 7-095/924-3038

Fax: 7-095/924-0490

Moscow Industrial Bank

5 Ordzhonikidze Street

Moscow 117419

Russia

Tel: 7-095/952-7408

Fax: 7-095/952-7794

Tokobank

7, Masha Poryvaeva Street

Moscow 107078

Russia

Tel: $7-095 / 204-7000$

Fax: 7-095/975-2578

\section{F. TECHNICAL ASSISTANCE \& TRAINING:}

\section{F.1. U.S. Government Sources}

Nunn-Lugar Funds

The Nunn-Lugar Act of 1991 provided for defense conversion assistance to the NIS. The four republics that are recipients of defense conversion assistance are the Russian Federation, Belarus, Ukraine, and Kazakhstan.

Nunn-Lugar is a $\$ 1.2$ billion program authorized by Congress for the funding of US assistance to republics of the former Soviet Union to (1) destroy nuclear, chemical, and other weapons; (2) safely transport, store, disable, and safeguard weapons in conjunction with their destruction; and (3) establish safeguards against their proliferation. The program authorized funds in $\$ 400$ million increments for FY 1992, 1993 and 1994 to the Department of Defense under the Defense Appropriations Act. It is anticipated that an additional $\$ 400$ million will be made available for FY 1995 . There are no definitive plans beyond 1995. The Nunn-Lugar Act has been recently renamed the "Cooperative Threat Reduction (CTR) Program." The Defense Nuclear Agency has been delegated the authority for program and financial management, procurement, and performance oversight. Support for Russia has been targeted for industry conversion and housing demobilization programs currently underway.

U.S. companies interested in bidding on contracts under the Nunn-Lugar program should track opportunities announced in the Commerce Business Daily or contact the Defense Nuclear Agency Hotline at $703 / 325-1175$. 


\section{Eurasia Foundation}

Established with the support of USAID, the Eurasia Foundation is a private, non-profit organization that supports technical assistance, training, and educational and policy programs in the NIS. The Foundation's objectives are to support private sector development, public sector reform, and media and communications. Although the Foundation is looking to support approximately $\$ 16$ million in grants per year, the average size grant will remain in the range of $\$ 50,000$ to $\$ 75,000$ but may consider grants up to $\$ 150,000$. Grant proposals must demonstrate support of private sector development and/or democratic institution building; indigenous institution building and strengthening; and transfer, adaptation, or development of local skills. Letters of inquiry regarding project proposals should be addressed to the contact below.

\section{Contact: Program Office}

Eurasia Foundation

1527 New Hampshire Avenue, NW

Washington, DC 20036

\section{U.S. Agency for International Development (USAID)}

\section{- $\quad$ Energy Efficiency and Market Reform}

USAID established a NIS Task Force in January 1992 to support technical and humanitarian assistance programs in NIS region. Approximately $\$ 235$ million for FY92 and $\$ 410$ million for FY93 was authorized under the Freedom Support Act. In FY94, USAID budgeted $\$ 215$ million for energy sector projects in the NIS. Approximately $\$ 75$ was budgeted for FY95. The project has four components: efficiency and performance improvement; production and delivery systems; pricing, policy and institutional reform; and nuclear power plant safety and regulation.

USAID has supported numerous activities in Russia to date: energy efficiency improvements in district heating systems, establishment of an energy efficiency center, work with DOE on analyzing alternatives to nuclear based power and ways to shut down plutonium production facilities, technical assistance to support a World Bank ga distribution loan, establishment with DOE of an Oil and Gas Center in Western Siberia to facilitate transfer of technology, assistance on the management and safety of coal mines in the Kuzbass and Vorkuta regions, identification of investments in thermal and hydro power plants, establishment of an energy industry partnership program between NIS and U.S. companies to transfer information on free market energy sector operations and management practices, development of petroleum commodity exchange in Moscow, and the improvement of safety and operations of the Balakovo power plant in Russia.

New initiatives underway are activities to perform energy audits at district heating facilities at other locations, undertake a study of alternative energy sources in Russia, development and application of reduced sulphur and nitrogen emissions in coal combustion, screening and analysis of investment needs of GAZPROM's capacity, upgrade nuclear and fire safety systems, implement training program for plant personnel, install safety/accident alert system in plant in Moscow, privatize the state-owned electric energy company, reform price and tariff structure, and introduce an appropriate regulatory energy framework.

All USAID programs are administered in conjunction with the USAID representative in country. 
Contact: Robert Ichord, Director

Office of Energy and Infrastructure

Bureau for Europe \& NIS

USAID

Washington, DC 20453

Tel: $202 / 647-8274$

Fax: 202/647-6962

-or-

Gene George

USAID Representative

Office of Energy

Tel: 7-095/956-4281

Fax: 7-095/956-3406

- International Executive Service Corps

$\$ 1$ million in funds were provided to USAID under the Foreign Appropriations Act of 1994 to support the International Executive Service Corps (IESC). USAID provided a $\$ 1$ million grant to IESC in FY 1992 to support general industry conversion activities. Technical advisors were placed in 4 cities: Nizhniy Novgorod and Yekaterinburg, Russia; Kharkhiv, Ukraine; and Almaty, Kazakhstan. This program will run until the end of FY 1994. DOD will continue to support this effort in FY 1995 providing the IESC with $\$ 1$ million per year.

Contact: Richard Shriver, Vice President

IESC

Stamford Harbor Park

333 Ludlow Street

Stamford, CT 06902

Tel: 203/967-6342

Fax: 203/359-3233

- $\quad$ Energy Partnership Program

Through the support of USAID, the U.S. Energy Association launched the Utility Partnership Program in July 1992. The Partnership Program links U.S. utilities with those in the NIS region to form industry partnerships between U.S. electric power and natural gas utilities and associations with their counterparts in the NIS. The objective of the program is to enable energy executives to work together in reshaping the NIS energy industry by introducing new concepts and industry structure and management under a free enterprise system. The areas of focus are industry restructuring, general utility management, energy efficiency, and the environment. In Russia, there are currently seven energy partnerships that have been established. 
Contact: William Polen, Program Manager

U.S. Energy Association

1620 Eye Street, NW, Suite 1000

Washington, DC 20006

Tel: 202/331-0415

Fax: $\quad 202 / 659-0578$

\section{U.S. Department of Agriculture (USDA)}

USDA provides export credit guarantees, export subsidies, and food aid throughout the NIS region to facilitate commodity exports. USDA also has a number of on-going technical assistance programs to provide support for agricultural reform and environmentally-sound agricultural practices.

\section{Contact: DeAndra Beck}

Director, CEE \& NIS Programs

U.S. Department of Agriculture

South Building Room 3214

Washington, DC $20250-4300$

Tel: $202 / 720-8875$

Fax: 202/690-0892

Special American Business Internship Training Program (SABIT)

Through the support of USAID, SABIT provides support for the exchange of senior NIS scientists and managers to come to the U.S. for a three to six month training internship with U.S. companies. The SABIT program provides NIS managers and scientists with hands-on experience in working in the U.S. to familiarize them with U.S products, services, and management techniques in their field of expertise. Training NIS scientists in U.S. companies allow them to apply their skills to peaceful research and development and expose them to the role of scientific research in a market economy. SABIT focuses on the agribusiness, defense conversion, energy, environment, medical, telecommunications, financial services, transportation, and medical/pharmaceutical/health care management areas. SABIT grants to U.S. firms help to defray the cost of the internships. This program is managed by the U.S. Department of Commerce.

\section{Contact: Liesel Duhon-Winski \\ SABIT \\ U.S. Department of Commerce \\ Washington, DC 20230 \\ Tel: $202 / 482-0073$ \\ Fax: 202/482-2443}

Consortia of American Businesses in the Newly Independent States (CABNIS)

CABNIS has provided grants to trade organizations to establish a non-profit consortia to assist small- and medium-sized companies in key sectors develop a commercial presence in the NIS region. The consortia provides member companies with export information, trade leads, marketing and promotional services. This effort is managed by the U.S. Department of Commerce. 
Contact: Eric Cimon

U.S. Department of Commerce

International Trade Administration

Washington, DC 20230

Tel: $202 / 482-5004$

Fax: 202/482-1790

\section{F.2. Multilateral Sources}

\section{World Bank}

\section{- Energy Efficiency Cross-Support Team}

In addition to the Russia and energy divisions of the World Bank, the Industrial and Energy Department of the Central Vice-Presidency for Finance and Private Sector Development of the World Bank provides cross-support for sectoral and geographic departments of the Bank. Crosssupport is provided for project lending, institutional development, and technical assistance related to energy efficiency and conservation, and rural, household, and renewable energy initiatives. This cross-support team can provide implementation support for energy efficiency components of ongoing Bank project lending and technical assistance as well as assess and monitor state-of-the-art technology and energy management practices for key end-user sectors.

Contact: Karl Jechoutek, Division Chief

Industry and Energy Department

Vice Presidency for Finance and Private Sector Development

World Bank

Washington, DC 20433

Tel: $202 / 458-6391$

Fax: 202/477-0542

\section{F.3. In Country Sources}

Moscow Center for Energy Efficiency (CENEf)

CENEf is a non-profit, non-governmental organization established in partnership with Battelle, Pacific Northwest Laboratory and the Energy Research Institute of the Russian Academy of Sciences in September 1991. The main objectives of CENEf are to demonstrate projects using state-of-the-art energy efficiency technologies and provide support to Russian and Western investors seeking to create joint ventures in production and distribution of energy-saving technologies; assist in drafting energy efficiency policy and legislation and policy; develop proposals to implement energy efficicncy measures and economic incentives to promote energy savings; and to develop information databases and information networks as well as to promote awareness of the ecological and economic benefits of energy conservation. For U.S. companies seeking to do business in Russia, CENEf can provide market information on the market for energy efficiency, business opportunities, assistance in financial matters, logistical and translation support, and information on relevant legislation. 
Contact: Igor Bashmakov CENEf

Verkhniya St. 1, Ste. 16

127550 Moscow

Russia

Tel \& Fax: 7-095/482-2507 


\section{G. INDEX}

Bank of America $\ldots \ldots \ldots \ldots \ldots \ldots \ldots \ldots \ldots \ldots \ldots \ldots \ldots \ldots \ldots \ldots \ldots$

Brunswick Fund $\ldots \ldots \ldots \ldots \ldots \ldots \ldots \ldots \ldots \ldots \ldots \ldots \ldots \ldots \ldots \ldots$

CARESBAC (CARE Small Business Assistance Corporation) . . . . . . . . . . . . . 1-5

Chase Manhattan Bank . . . . . . . . . . . . . . . . . . . . . . . 1-26

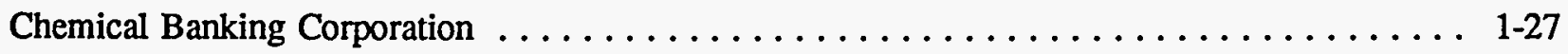

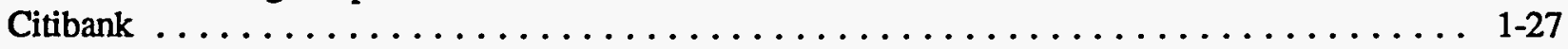

Committee on Energy Efficiency Commerce and Trade (COEECT) . . . . . . . . . . . . 1-3

Committee on Renewable Energy Commerce and Trade (CORECT) $\ldots \ldots \ldots \ldots \ldots \ldots \ldots \ldots$ 1-2

Consortia of American Businesses in the NIS (CABNIS) $\ldots \ldots \ldots \ldots \ldots \ldots \ldots \ldots \ldots$. $\ldots \ldots 2$

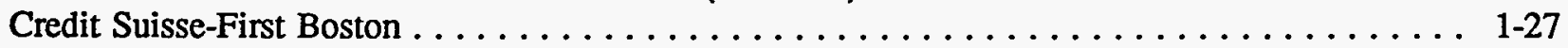

The Defense Enterprise Fund $\ldots \ldots \ldots \ldots \ldots \ldots \ldots \ldots \ldots \ldots \ldots \ldots \ldots \ldots \ldots \ldots$

Environmental Enterprises Assistance Fund (EEAF) $\ldots \ldots \ldots \ldots \ldots \ldots \ldots \ldots \ldots \ldots$

Eurasia Foundation $\ldots \ldots \ldots \ldots \ldots \ldots \ldots \ldots \ldots \ldots \ldots \ldots \ldots \ldots \ldots$

European Bank for Reconstruction and Development (EBRD) $\ldots \ldots \ldots \ldots \ldots \ldots \ldots \ldots \ldots$ 1-22

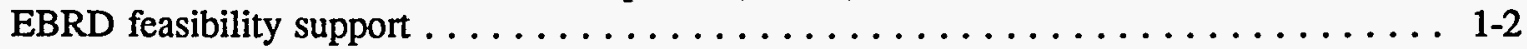

EBRD Small Business Fund $\ldots \ldots \ldots \ldots \ldots \ldots \ldots \ldots \ldots \ldots \ldots \ldots \ldots$

Export-Import Bank of the United States (EXIM) $\ldots \ldots \ldots \ldots \ldots \ldots \ldots \ldots \ldots \ldots \ldots$

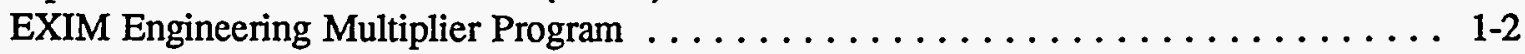

EXIM Project Finance Program $\ldots \ldots \ldots \ldots \ldots \ldots \ldots \ldots \ldots \ldots \ldots \ldots \ldots$

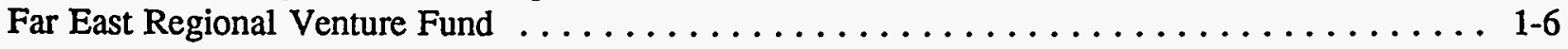

First NIS Regional Fund $\ldots \ldots \ldots \ldots \ldots \ldots \ldots \ldots \ldots \ldots \ldots \ldots \ldots \ldots \ldots$

First Russian Frontiers Trust PLC $\ldots \ldots \ldots \ldots \ldots \ldots \ldots \ldots \ldots \ldots \ldots \ldots \ldots \ldots \ldots \ldots$

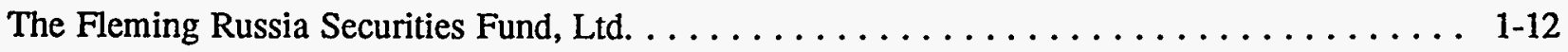

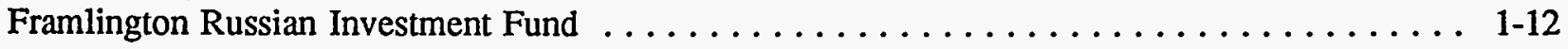

Fund for Large Enterprises in Russia (FLER) $\ldots \ldots \ldots \ldots \ldots \ldots \ldots \ldots \ldots \ldots \ldots$

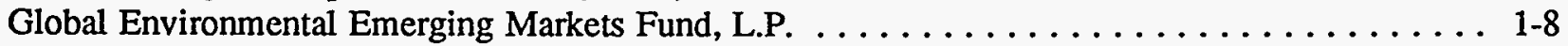

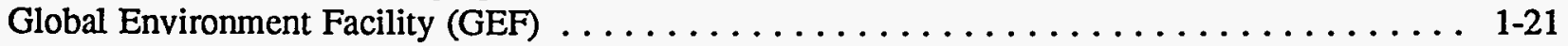

Inkombank . . . . . . . . . . . . . . . . . . . . . . . . . . . . . 1-28

International Bank for Reconstruction and Development (WORLD BANK) $\ldots \ldots \ldots \ldots \ldots$ 1-19

International Finance Corporation (IFC) $\ldots \ldots \ldots \ldots \ldots \ldots \ldots \ldots \ldots \ldots \ldots \ldots \ldots \ldots$. $\ldots \ldots \ldots$

Intemational Fund for Renewable Energy and Energy Efficiency (IFREE). . . . . . . . . . . . . 1-1

International Moscow Bank . . . . . . . . . . . . . . . . . . . . . . . . 1-28

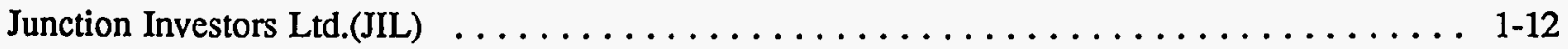

Mosbusinessbank (Moscow Bank for Business Promotion) . . . . . . . . . . . . . . . . . . 1-29

Moscow Center for Energy Efficiency (CENEf) $\ldots \ldots \ldots \ldots \ldots \ldots \ldots \ldots \ldots \ldots \ldots$

Moscow Industrial Bank . . . . . . . . . . . . . . . . . . . . . . . . . . . . . . 1-29

Moscow Import-Export Bank $\ldots \ldots \ldots \ldots \ldots \ldots \ldots \ldots \ldots \ldots \ldots \ldots \ldots \ldots \ldots$

NCH Advisors . . . . . . . . . . . . . . . . . . . . . . . . . . 1-13

New Europe East Investment Fund $\ldots \ldots \ldots \ldots \ldots \ldots \ldots \ldots \ldots \ldots \ldots \ldots \ldots \ldots$

New Russian Small Business Investment Fund $\ldots \ldots \ldots \ldots \ldots \ldots \ldots \ldots \ldots \ldots \ldots \ldots \ldots$

Newstar Fund $\ldots \ldots \ldots \ldots \ldots \ldots \ldots \ldots \ldots \ldots \ldots \ldots \ldots \ldots \ldots \ldots \ldots \ldots$

NIS Industrial Partnering Program $\ldots \ldots \ldots \ldots \ldots \ldots \ldots \ldots \ldots \ldots \ldots \ldots \ldots \ldots \ldots$

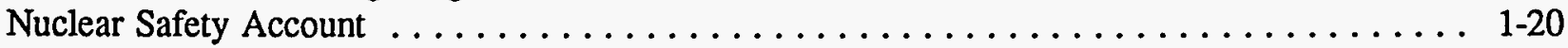


Nunn-Lugar Funds . . . . . . . . . . . . . . . . . . . . . . . . . . . . . . . . . 1-29

Overseas Private Investment Corporation (OPIC) $\ldots \ldots \ldots \ldots \ldots \ldots \ldots \ldots \ldots \ldots \ldots$

Pioneer Fund . . . . . . . . . . . . . . . . . . . . . . . . . . . . 1-14

Red Tiger Investment Co. Ltd $\ldots \ldots \ldots \ldots \ldots \ldots \ldots \ldots \ldots \ldots \ldots \ldots \ldots \ldots \ldots \ldots \ldots$

The Russian-American Enterprise Fund $\ldots \ldots \ldots \ldots \ldots \ldots \ldots \ldots \ldots \ldots \ldots \ldots \ldots \ldots$

Russia and the Republics Equity Partners LP (RARE) . . . . . . . . . . . . . . . 1-14

Russia/NIS Major Projects Fund . . . . . . . . . . . . . . . . . . . . . . 1-9

Russia Partners Fund . . . . . . . . . . . . . . . . . . . . . . . 1-9

Russian Sector Development Corporation . . . . . . . . . . . . . . . . . . 1-15

Russian Energy Savings Fund (RESF) . . . . . . . . . . . . . . . . . . . . 1-20

Russian Commodity Import Program (CIP) . . . . . . . . . . . . . . . . . . 1-25

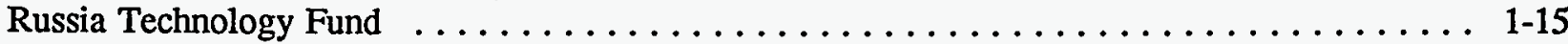

Russia Value Fund, L.P. . . . . . . . . . . . . . . . . . . . . . . . . . . 1-15

Russian Venture Capital Fund of America $\ldots \ldots \ldots \ldots \ldots \ldots \ldots \ldots \ldots \ldots \ldots$

St. Petersburg Regional Venture Fund $\ldots \ldots \ldots \ldots \ldots \ldots \ldots \ldots \ldots \ldots \ldots \ldots \ldots \ldots \ldots$

Smolensk Regional Venture Fund . . . . . . . . . . . . . . . . . . . . . . . 1-10

Special American Business Internship Training Program (SABIT) $\ldots \ldots \ldots \ldots \ldots \ldots \ldots \ldots$

Tokobank . . . . . . . . . . . . . . . . . . . . . . . . . . . . . . . . . . . . . 1-29

Urals Regional Venture Fund $\ldots \ldots \ldots \ldots \ldots \ldots \ldots \ldots \ldots \ldots \ldots \ldots \ldots \ldots \ldots \ldots \ldots \ldots \ldots \ldots \ldots$

U.S. Agency for International Development (USAID)

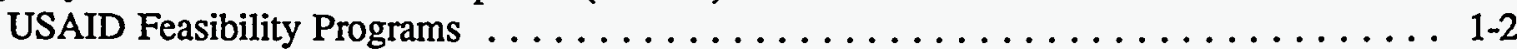

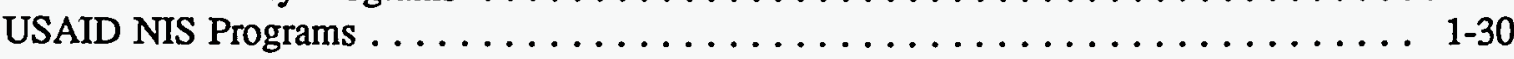

U.S. Department of Agriculture (USDA) $\ldots \ldots \ldots \ldots \ldots \ldots \ldots \ldots \ldots \ldots \ldots \ldots \ldots \ldots$

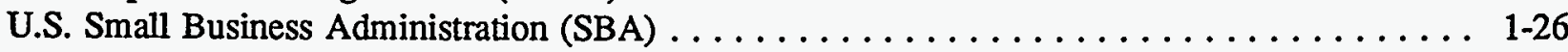

U.S. Trade and Development Agency (TDA) $\ldots \ldots \ldots \ldots \ldots \ldots \ldots \ldots \ldots \ldots \ldots \ldots \ldots \ldots \ldots$

Rosvneshtorgbank (VTB) - Russian Bank for Foreign Trade . . . . . . . . . . . . . . . . . . . 1-27

Vnesheconombank (VEB) - Bank for Foreign Economic Affairs . . . . . . . . . . . . . 1-28

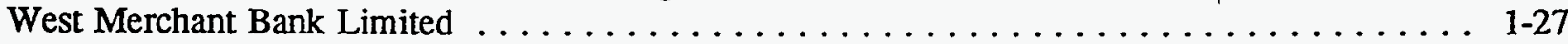

World Bank $\ldots \ldots \ldots \ldots \ldots \ldots \ldots \ldots \ldots \ldots \ldots \ldots \ldots \ldots \ldots \ldots \ldots \ldots$ 


\section{UKRAINE}


$\ldots$ 


\section{A. FEASIBILITY FINANCING:}

\section{A.1. U.S. Government Sources}

\section{U.S. Trade and Development Agency (TDA)}

TDA is an independent, U.S. government agency that provides funding for feasibility studies, training programs, and seminars. TDA supports major projects in the public sector that offer large export or investment potential for U.S. companies. All proposed projects must have the host government's approval, meet the country's development priorities, create significant U.S. export potential, and offer untied financing options. TDA's participation usually ranges from $\$ 150,000$ to $\$ 750,000$.

Contact: Dan Stein, Regional Manager

Russia \& Newly Independent States

U.S. Trade and Development Agency

1621 North Kent Street

Arlington, VA 22209

Tel: 703/875-4357

Fax: 703/875-4009

TDA also has trust fund accounts with multilateral institutions like the World Bank, International Finance Corporation (IFC), and European Bank for Reconstruction and Development (EBRD). This mechanism can be used to support feasibility studies that are tied to specific projects these institutions would likely support. In the case of the IFC, for example, project proposals must demonstrate that they are commercially viable and meet IFC investment threshold criteria as well as the funding requirements of TDA.

For IFC Trust Funds: Alakadri Bose

IFC

Tel: $202 / 473-0551$

Fax: 202/676-1513

For EBRD Technical Cooperation Funds:

Dr. Ullrich Kiermayr

Tel: 44-71/338-6356

Fax: 44-71/628-2530

At USTDA, Contact: Barbara Bradford

Tel: $703 / 875-4357$

Fax: 703/875-4009

The International Fund for Renewable Energy and Energy Efficiency (IFREE)

Funded by the U.S. Agency for International Development, U.S. Department of Energy, the Rockefeller Foundation, and the U.S. Environmental Protection Agency, IFREE facilitates increased access to funding for renewable energy, energy efficiency, and, generally, environmentally-sound projects in developing countries. Under the Prefeasibility Study Program, IFREE offers up to $\$ 50,000$ to support up to 50 percent of prefeasibility study costs, which enables project developers to secure project finance or additional funding for detailed project analyses required by private lenders and U.S. government agencies for the evaluation of projects. Energy efficiency and renewable energy, i.e., biomass, geothermal, small hydropower, natural gas, solar photovoltaic, solar thermal, or wind energy projects are considered. Projects 
must be commercially viable, identify sources of funding for the full feasibility study and in-country partners, and use predominantly U.S. equipment, materials, and services.

Contact: Patrick D'Addario

IFREE

777 North Capital Street, NE, Suite 805

Washington, DC 20002

Tel: $202 / 408-7916$

Fax: 202/371-5i16

U.S. Agency for International Development (USAID) - Feasibility Support

USAID routinely supports feasibility studies in targeted sectors in the Newly Independent States (NIS) region, namely energy, environment, agribusiness, housing, private sector and financial sector development. Interested parties should track opportunities in the Commerce Business Daily.

Contact: Commerce Business Daily

Tel: $202 / 783-3238$

Fax: 202/512-2233

Committee on Renewable Energy Commerce and Trade (CORECT)

CORECT is an interagency working group comprised of representatives from 14 U.S. Federal government agencies, chaired by the U.S. Department of Energy. CORECT works closely with the U.S. Export Council for Renewable Energy (US/ECRE), an industry consortium of seven renewable energy trade associations, to promote renewable energy exports in international markets and ensure that renewable energy technologies and applications are integrated in development projects.

Contact: Ronald Bowes, Director

Office of Technical Assistance

Energy Efficiency and Renewable Energy

U.S. Department of Energy

1000 Independence Avenue, SW, Room 5E-036

Washington, DC 20585

Tel: 202/586-2959

Fax: 202/586-1605

Committee on Energy Efficiency Commerce and Trade (COEECT)

COEECT is an interagency working group comprised of representatives from 14 U.S. Federal government agencies, chaired by the U.S. Department of Energy. COEECT works closely with the Energy Efficiency Export Council to undertake market assessment for energy efficiency products and services, identify project financing from federal and multilateral institutions, and address the specific needs of the energy efficiency products and services industry. 
Contact: Ronald Bowes, Director

Office of Technical Assistance

Energy Efficiency and Renewable Energy

U.S. Department of Energy

1000 Independence Avenue, SW, Room 5E-036

Washington, DC 20585

Tel: 202/586-2959

Fax: 202/586-1605

\section{A.2. Multilateral Sources}

European Bank for Reconstruction and Development (EBRD)

EBRD does perform pre-investment and/or feasibility studies usually for projects in which it is interested in investing. Interested parties should track the EBRD procurement notice bulletins. To obtain information on EBRD procurement opportunities, contact the representatives below.

Contact: Sara Shackelton, Commercial Specialist

Office of the U.S. Executive Director

One Exchange Square

London EC2A 2EH

England

Tel: $44-71 / 338-6569$

Fax: 44-71/338-6487

-or-

Matt Handwork

Office of Multilateral Bank Operations

U.S. Department of Commerce

Washington, DC 20230

Tel: 202/482-3399

Fax: 202/273-0927

\section{A.3. In Country Sources}

No known available sources.

\section{B. PROJECT FINANCE - PRIVATE SECTOR:}

\section{B.1. U.S. Government Sources}

Overseas Private Investment Corporation (OPIC)

This independent, U.S. government agency provides project financing, investment insurance, and a variety of investor services. OPIC is currently open for business in all countries in the NIS except Azerbaijan. OPIC has recently supplemented its finance products by supporting privately owned and managed equity 
investment funds. OPIC is currently supporting equity funds that will invest in environmental enterprises worldwide, including Ukraine.

\section{Project Financing:}

OPIC provides medium to long-term financing (over 3 years), available through loan guarantees and/or direct loans. Loan guarantees cover both commercial and political risks. OPIC has approximately $\$ 1$ billion available to finance projects in the NIS. OPIC offers direct loans for international investment projects, which range from $\$ 2$ to $\$ 200$ million. However, OPIC typically does not support projects under $\$ 10$ million. OPIC will participate in up to 50 percent of the total project cost for a new venture and up to 75 percent of the total cost of an expansion.

Contact: John Harper, Regional Manager

Russia \& Newly Independent States

Overseas Private Investment Corporation

1100 New York Avenue, NW

Washington, DC 20527

Tel: $202 / 336-8494$

Fax: 202/408-9866

The investment funds listed below have been capitalized primarily with funds from U.S. government and multilateral organizations:

The Defense Enterprise Fund

The Defense Enterprise Fund was established as a non-profit corporation to promote private sector investment in restructuring the Ukrainian dcfense industry. The Fund supports investments involving the personnel and/or facilities currently or formerly involved in research, development, production or operation, and conversion of large defense enterprises, which previously contributed to production of weapons of mass destruction. The Fund also makes investments in private sector spin-off initiatives from large defense enterprises and start-up initiatives by former defense or military personnel. This Fund will provide debt or equity support to enterprises that have privatized or that have already committed in writing to privatization. An enterprise is considered privatized if greater than 50 percent of ownership and control is held in the private sector.

Contact: Michael Lehner, Vice President/Investment Manager

Defense Enterprise Fund

104 Crofton Road

Waban, MA 02168

Tel: $617 / 527-3307$

Fax: 617/527-2722

Ukraine Fund

Formed in 1992, the equity fund focuses exclusively on the Ukraine and Ukrainian companies that produce goods and services for the domestic market. This Fund is capitalized at $\$ 11.8$ million by private investors and contributions from the EBRD, IFC, and Bank of Boston. Of particular interest to the Fund is investments in the consumer goods area. Investments generally range from $\$ 100,000$ to $\$ 300,000$, The Fund looks to invest in companies that can establish long-term value and have a strong competitive position in the domestic marketplace. To date, $\$ 4$ million has been invested in 18 companies, such as furniture manufacturer, tea packing company, food and beverage distributor, and printing facility, etc. 
Contact: Alexander Grenyuk or Irene Schmid

Ukraine Fund

20 Pushkynskaya, Apr. 26

Kiev 254004, Ukraine

Tel: 7-044/228-6216

Fax: 7-044/228-0916

-or-

Tom Claflin, Partner

Claflin Capital Management, Inc.

77 Franklin Street

Boston, MA 02110

Tel: $617-426-6505$

Fax: 617-482-0016

Western NIS Enterprise Fund

The Western NIS Enterprise Fund was established in July, 1994 to make equity investments and loans, and offer technical assistance to promote new private companies and entrepreneurs in Belarus, Moldova, and Ukraine. USAID will capitalize the fund with $\$ 150$ million over the next 3 to 5 years. The focus of the Fund is on small- and medium-sized private and privatizing companies. Firms with as many as 2,500 employees will be considered although most investments and assistance will be targeted at firms smaller than this threshold.

Contact: Western NIS Enterprise Fund

885 Third Avenue, Suite 1000

New York, NY 10022

Tel: $212 / 906-1235$

Fax: $212 / 751-4864$

-or-

Western NIS Enterprise Fund

\#7 Kudriavsky Uzviz, 2nd Floor

254053 Kiev Ukraine

Tel: 7-044/416-9841

Fax: 7-044/417-1419

Environmental Enterprises Assistance Fund (EEAF)

EEAF invests in projects and companies in developing countries. The main objective of EEAF is to catalyze the spread of renewable energy, energy efficiency, and other environmentally responsible technologies. EEAF provides direct loans and equity placements in environmentally-sound, commercially viable projects and capitalizes local investment funds. EEAF provides financial support for projects under $\$ 2$ million in renewable energy systems, energy efficient technologies, and environmentally responsible management of organic waste. Direct loans are made at concessional rates, but equity investments are expected to provide higher returns than conventional financing arrangements. On a limited, costreimbursable basis, EEAF may provide technical assistance for training and technical analysis of proposed projects. 
Contact: Brooks Browne, President

Environmental Enterprises Assistance Fund

1901 North Moore Street

Suite 1004

Arlington, VA 22209

Tel: $703 / 522-5928$

Fax: $703 / 522-6450$

First NIS Regional Fund

The First NIS Regional Fund is a $\$ 160$ million close-ended investment fund managed by Baring Investment Management Ltd. The main objective of the Fund is to achieve long-term growth through equity and equity-related investments in NIS companies; those that are over-the-counter privatized corporations, joint stock companies, joint ventures, or partnerships. The primary sectors in which investments will be made will be natural resources-related companies, infrastructure, and telecommunications, which will represent 60 percent of the Fund's investments. The remaining 40 percent will be dedicated to light manufacturing, consumer products and services, and real estate. EBRD provided \$20 million in equity commitments, and $\$ 15$ million from the IFC. $\$ 20$ million for the debt portion of the Fund is expected from OPIC to cover loan guarantees.

The Fund bases their investment decisions upon the ability of NIS companies prospect for long-term growth: whether the company has foreign currency reserves or substantial export earning potential; human, technical, financial and/or other resources necessary to compete in the marketplace; substantial assets; international accounting standards; potential for long-term earnings and cash flow growth; and a sound business strategy. The Fund is managed by Baring Asset Management.

Contact: Richard Sobel, Director, Institutional Group

Baring Asset Management

155 Bishopsgate

London EC2M 3XY

England

Tel: 44-71/214-1871

Fax: 44-71/214-1635

\section{Global Environmental Emerging Markets Fund, L.P.}

This fund is designed to take significant minority equity or equity-related positions in private companies in emerging markets in Africa, Asia, Latin America, and Eastern Europe. The Fund has raised $\$ 70$ million in capital through an offering of its securities to sophisticated investors, including financial institutions, in the U.S. and Europe. These securities will be partnership equity interests and OPIC-guaranteed longterm partnership notes, offered together or separately. The Fund will invest up to $\$ 10$ million in alternative energy, water treatment, air pollution control and waste management. Currently, the Fund is looking at a number of opportunities in the area of energy conservation and demand side management. The Global Environment Fund, L.P. manages this new fund and serves as its general partner. Projects are currently being sought for review and consideration. 
Contact: H. Jeffrey Leonard, President

Global Environmental Fund, L.P.

1250 24th Street, NW, Suite 600

Washington, DC 20037

Tel: 202/466-0529

Fax: 202/466-6454

New Europe East Investment Fund

Managed by Capital International, Inc., this $\$ 130$ million fund was launched in June 1993 with capital contributions by the EBRD, the International Financial Corporation (IFC), and pension funds. The Fund will make direct investments in privatized companies or newly established ventures in Central and Eastern Europe and the NIS that are managed by established Western industrial group. Investments range from $\$ 5$ - $\$ 15$ million. Up to a 20 percent stake is taken in each issuer's securities.

Contact: Mr. Lam Nguyen-Phuong

Capital International, Inc.

25 Bedford Street

London WC2E 9HN

England

Tel: 44-71/257-6700 Fax: 44-71/257-6767

\section{Russia Partners Fund}

This $\$ 155$ million fund will invest primarily in equity and equity-related instruments of privatized and privatizing companies, greenfield investments, and start-up ventures in the NIS. The Fund will invest in hard-currency generating or export production businesses and sectors that offer high returns such as natural-resources, light manufacturing, telecommunications, distribution, and consumer products and services. The average size investment will range from $\$ 2$ to $\$ 15$ million. OPIC has fully guaranteed the Fund. Projects should demonstrate the ability to generate long-term revenue growth potential and high profit margins. The Fund may seek co-investment or other types of participation from Western partners. The local advisor to the Fund is International Economic Cooperation Company, a private Russian company. The Fund is managed by PaineWebber Inc., New York, through its asset management subsidiary Mitchell Hutchins Asset Management Inc.

Contact: Drew Guff, Fund Manager

PaineWebber

1285 Avenue of the Americas, 14th floor

New York, NY 10019

Tel: 212/713-3214

Fax: 212/713-1087

-or-

Lauralee Raddatz

Myasnitskaya Ulitsa, Dom 35

101959 Moscow

Russia

Tel: 7-095/207-9140

Fax: 7-095/975-2449 
Russia/NIS Major Projects Fund

This fund will invest in equity and equity-related securities. OPIC will guarantee up to 75 percent of up to $\$ 300$ million. The Fund will concentrate on the telecommunications, energy, transportation, and metals processing sectors. Investments will range from $\$ 10$ to $\$ 20$ million. This fund is not as yet operational; it is expected to be fully operational by the Summer, 1995.

Contact: Graham Williams, Managing Director

Overseas Private Investment Corporation

1100 New York Avenue, NW

Washington, DC 20527

Tel: $202 / 336-8479$

Fax: 202/408-9866

The investment funds listed below have been capitalized primarily with funds from private sources:

First Russian Frontiers Trust PLC

Managed by Pictet Asset Management, this fund is capitalized approximately at $\$ 60$ million. The Fund will invest in a diversified portfolio of securities of countries in the NIS and Central and Eastem Europe regions. Initially, Russia, Ukraine, Uzbekistan, Bulgaria, and Romania will be the focus of the Fund. 15 percent of the Fund's portfolio will be invested in the more developed markets in Central and Eastern Europe.

Contact: Douglas Polunin, Senior Investment Manager

5 Devonshire Square

EC2M 4LD London

England

Tel: $44-71 / 972-6800$

Fax: 44-71/972-6876

Junction Investors Ltd. (JIL)

This venture capital fund is capitalized at $\$ 50$ million by private sources. The Fund provides equity investments and arranges for debt and/or additional equity funding for small- and medium-sized businesses that demonstrate the potential for long-term growth and infrastructure development. Investments range from $\$ 1$ to $\$ 5$ million.

Contact: Thomas R. DiBenedetto, President

Junction Investors Ltd.

84 State Street, 2nd Floor

Boston, MA 02109

Tel: $617 / 248-9600$

Fax: 617/248-9652

\section{NCH Advisors}

This group was launched with $\$ 160$ million of capital from large institutional investors and U.S. and European investment managers in 1993. This group provides equity in existing businesses, start-up capital, joint venture financing, short- and medium-term financing, real estate financing and the purchase of government and commercial obligations. Natural resources, telecommunications, banking, real estate, agrobusiness, pharmaceutical, and high technology are targeted sectors for investment. 
Contact: Alexander Papachristou

NCH Advisors

635 Madison Avenue, 4th Floor

New York, NY 10022

Tel: $212 / 308-4343$

Fax: 212/308-4398

\section{Newstar Fund}

This fund is a small venture capital and merchant bank operation capitalized at approximately $\$ 20$ million. Newstar invests in equity in private, small- to medium-sized undervalued companies that are that are export oriented with a strong management and solid cash flow potential. Projects must involve a Westem partner. The Fund is interested in supporting investments in the range of $\$ 500,000$ to $\$ 5$ million.

Contact: Brad Wegner, Manager of Investment

Newstar, Inc.

1001 Pennsylvania Avenue, NW, Suite 480-North

Washington, DC 20004

Tel: $202 / 783-4155$

Fax: 202/628-5986

-or-

Jeffrey Hammer, Director of Investments

Vspolni Pereulok, 19/20

103001 Moscow, Russia

Tel: 7-095/291-8338/8341

Fax: 7-095/291-2926

Satellite Fax: 7-502/221-1470

\section{B.2. Multilateral Sources}

European Bank for Reconstruction and Development (EBRD)

EBRD provides loans, equity investments, debt guarantees, debt and equity underwriting, advice, and technical cooperation to promote private and entrepreneurial initiatives and foster transition toward democratic, market-oriented economies in the CEE and NIS regions. The Bank does not issue guarantees for export credits or undertake insurance activities. The Bank's operations are structured along geographic lines: Northern and Southern tier country teams headed by two vice presidents that report directly to EBRD President Jacques de Larosière. The Ukraine country team falls under the Southern Tier Vice Presidency. Each country team brings together merchant and development banking operations, sectoral expertise (i.e., natural resources and tourism, power and energy utilities) and cross-support functions (i.e., environmental appraisals, procurement, syndication) for each country team.

The mandate of the EBRD requires that 60 percent of its loans be directed to funding private enterprises and privatization efforts. These loans are more risky than World Bank loans, which carry sovereign guarantees. The balance of its funding is directed to physical and financial infrastructure or development projects. EBRD will only finance projects that benefit the country in which they are located. Although U.S. companies may approach the Bank with specific project proposals, host government support is looked upon favorably. 
Contact for Ukraine: Mark Tomlinson

Ukraine Country Team

One Exchange Square

London EC2A 2EH

England

Tel: 44-71/338-6566

Fax: 44-71/338-6159
EBRD Kiev Office: Lesia Haliv

Deputy Representative

EBRD

Room 407 National Hotel

Corpus I, no. 5 Lypska St.

Kiev 252021

Tel: 7-044/230-2626

Fax: 7-044/291-6246

Contact for Energy: Ananda Covindassamy

Power/Energy - Southern Tier

EBRD

One Exchange Square

London EC2A 2EH England

Tel: $44-71 / 338-6872$

Fax: 44-71/338-7280

International Finance Corporation (IFC)

IFC, a member of the World Bank, is the largest source of direct financing for private sector projects in developing countries. Unlike the World Bank, IFC lends directly to private companies and does not request guarantees from host-country governments. It can provide loans, make equity investments in private businesses, and mobilize additional loan and equity financing in international financial markets through syndication efforts. Although IFC invests and lends on market terms, it finances projects unable to obtain sufficient funding on reasonable terms from other sources. Increasingly, the IFC is working through intermediary financial facilities in order to support smaller scale projects and supporting cofinance arrangements with the World Bank (GEF) and EBRD.

Loans and equity investments are usually limited to no more than 25 percent of project cost. IFC's minimum investment project support is $\$ 10$ million. Funds may be used for foreign or local expenditures related to overall project costs, i.e, fixed assets, permanent working capital, interest during construction, and pre-operating cost. IFC can invest up to 35 percent of the share capital as long as it is not the major shareholder. It turns over its equity often by sale to local investors when the investment has matured. Both fixed and variable rate loans are offered; rates are determined on a commercial basis. Terms normally run from seven to twelve years.

Contact for Ukraine: Anthony Doran, Manager

Europe Department

International Finance Corporation

1850 I (Eye) Street, NW, Room I-9151

Washington, DC 20433

Tel: 202/473-3929

Fax: 202/676-9593 
Contact for Energy \& Environment: Martyn Riddle, Manager

Environmental Unit

International Finance Corporation

1850 Eye Street, NW

Washington, DC 20433

Tel: 202/473-0661

Fax: 202/676-9495

\section{B.3. In Country Sources}

No known available sources

\section{PROJECT FINANCE - PUBLIC SECTOR:}

\section{C.1. U.S. Government Sources}

NIS Industrial Partnering Program

The 1994 Foreign Operations Appropriations Act provided for a \$35 million NIS Industrial Partnering Program. The $\$ 35$ million effort is designed to promote partnerships involving US industry, universities, DOE National Laboratories and key institutes of the NIS. The main objective of this program is to assist NIS institutes with converting from defense to commercial applications and to prevent and reduce proliferation of weapons of mass destruction. As a general guideline, these funds will be allocated according to the following percentages: 80 percent Russian Federation, 10 percent Ukraine, 5 percent Belarus, and 5 percent Kazakhstan. This effort is managed by the Department of Energy (DOE).

This program consists of three components: $\$ 20$ million for stabilization, $\$ 12$ million for cost-shared industrial partnering, and $\$ 3$ million for academic support. The stabilization component provides $\$ 20$ million of funding to NIS institutes and DOE national laboratories to commercialize appropriate technologies. This program builds on existing linkages and prior collaboration among NIS institutes and DOE national laboratories. Project proposals are reviewed by an Inter-Laboratory Board and by DOE and the U.S. Department of State. The Inter-Laboratory Board will attempt to incorporate all project proposals into a comprehensive, unified program of scientific cooperation.

The $\$ 12$ million component for cost-shared industrial partnering is designed to promote the commercialization of technologies developed for the NIS weapon programs. An industrial consortium, US Industry Coalition (USIC), will be formed to develop and commercialize projects on a cost-shared basis with the laboratories. The $\$ 12$ million will be held in an escrow account for the purposes of developing projects. To supplement these funds, industry members are expected to contribute matching funds equivalent to approximately $\$ 8$ million in 1994. The goal of this program is to establish the framework and successful commercialization so that US companies can provide approximately $\$ 30$ million/year to initiate and renew partnerships with NIS weapon's institutes without US government assistance.

The remaining $\$ 3$ million will provide funding for a consortium of academic institutions led by the University of New Mexico to develop a telecommunications network, provide management and business training support to the NIS institutes and USIC. 
Contact: Michael Deegan, President

United States Industry Coalition

901 University Blvd., SE

Albuquerque, NM 87106-4339

Tel: $505 / 272-7344$

Fax: 505/272-7355

\section{C.2. Multilateral Sources}

International Bank for Reconstruction and Development (WORLD BANK)

The World Bank, a multilateral lending agency, is the largest source of financial and technical assistance to the public sector in developing countries. The Bank also makes policy-oriented structural and sectoral adjustment loans to support market-oriented institutional reforms. The Bank lends to member governments for public sector, development projects, not to the private sector. The Bank affiliate that lends to the private sector is the IFC. Loans are made only to governments or to agencies that can obtain a government guarantee for repayment. Bank funds are used by member governments to import food and equipment, fund project construction, and obtain consultant services. Interest rates on Bank loans are set a half a percentage point above the Bank's average cost of borrowing and repayment terms are normally twelve to fifteen years, including a three to five year grace period.

The Bank is particularly active in the energy sector, mostly in oil and gas-related projects. However, there is increased interest in supporting energy efficiency and conservation projects, especially in the CEE and NIS regions.

Contact for Ukraine: Basil Kavalsky, Department Director

Europe \& Central Asia Department

World Bank, Room H-4179

Washington, DC 20433

Tel: 202/458-0523

Fax: 202/522-0010

Contact for Energy: Jonathan Brown, Division Chief

Infrastructure, Energy \& Environment Division

World Bank, Room H3-139

Washington, DC 20433

Tel: 202/473-2469

Fax: 202/477-3285

Nuclear Safety Account

An outgrowth of the G-7 Munich Summit of 6-8 July, 1992, the Nuclear Safety Account was set up by the EBRD to receive contributions totalling ECU 115 million (approximatcly $\$ 150$ million) by donor countries for grants to support nuclear safety projects in countries in the CEE and NIS regions. The main objective of the Account is to finance, through grants, projects designed to implement immediate operational safety and technical safety improvement measures for nuclear reactors in the CEE and NIS regions. Priority will be given to those reactors that present a high level of risk which can be significantly reduced by short-term and cost-effective safety improvements, and to those reactors that are necessary to ensure the continuity of national electricity supply in the rcgion. The majority of the projects, therefore, will address security problems in existing REMK and VVER-230 reactors. Sincc donors are supporting 
efforts to undertake feasibility studies and technical assistance to address these problems, the Account will focus on providing the necessary funds to purchase equipment.

\section{Contact: Francois Demarcq, Director \\ Nuclear Safety Account \\ EBRD \\ One Exchange Square \\ London EC2A 2EH \\ England}

Tel: $44-71 / 338-6792$

Fax: 44-71/338-6109

\section{Global Environment Facility (GEF)}

Established in 1990, GEF provides grants for investment projects and technical assistance to assist developing countries to address four main global (transboundary) environmental problems: global warming, pollution of international waters, destruction of biological diversity, and depletion of the ozone layer. GEF is co-managed by the World Bank, U.N. Development Programme, and the U.N. Environmental Programme. To qualify for funding under the GEF, projects must be innovative, demonstrate the effectiveness of a particular technology or approach, and fall into one of the four priority areas. GEF funding is possible if the project offers substantial global benefits, but is unlikely to be viable without some concessional funding or if a project is economically viable but requires supplemental finance to bring about global benefits.

GEF projects can either be free-standing, components of World Bank projects, or pass through the IFC to support private sector ventures that have both important demonstration benefits and host government endorsement. Free-standing GEF projects are limited to $\$ 10$ million, and GEF components of World Bank projects must not exceed $\$ 30$ million. GEF funds can leverage regular Bank projects by paying the additional cost of incorporating environmentally benign technologies in Bank-supported projects. GEF funds would cover the difference in cost between what the host country is willing to pay and the cost of the benign technology. Use of GEF funds through the IFC can be used if the sponsor/lender could not otherwise underwrite the risk under prevailing market conditions; funds cannot be used to avert normal commercial risks.

Contact: Mr. Ken Newcombe, GEF Coordinator

World Bank, Room S2-141

Environment Division

Washington, DC 20433

Tel: $202 / 473-6010$

Fax: 202/522-3256
Ms. Jocelyn Albert

GEF Regional Coordinator

European Community \& Middle East

World Bank

Washington, DC 20433

Tel: 202/473-3458

Fax:202/522-3256

\section{C.3. In Country Sources}

No known available sources 


\section{COFINANCING:}

\section{D.1. U.S. Government Sources}

Not applicable.

\section{D.2. Multilateral Sources}

International Bank for Reconstruction and Development (World Bank)

Although the Bank mainly lends to governments and government agencies, it can also provide guarantees to commercial lenders for public and private sector projects. The Bank's guarantee program currently covers loans totalling $\$ 1$ billion. As a way to attract private sector capital and encourage direct foreign investments in developing countries, the Bank's Executive Directors approved a proposal making guarantees a mainstream instrument of Bank operations in September 1994. There are two types of guarantees offered: (1) partial risk guarantee that covers non-performance of sovereign contractual obligations or other contractual non-performance problems in a project and (2) partial credit guarantee which extends maturities beyond what private lenders could otherwise provide.

By covering risks that the market would not bear, the Bank's guarantee program helps reduce the cost of financing projects by guaranteeing against contractual non-performance, offers flexibility to structure project financing by extending maturities, and attracts private sources of capital by sharing risks of undertaking infrastructure projects in developing countries.

Contact: Nina Shapiro, Manager

Project Finance Group

Cofinancing and Financial Advisory Department

World Bank

Tel: $202 / 473-1650$

Fax: 202/477-0218

European Bank for Reconstruction and Development (EBRD)

The EBRD utilizes both private and official cofinancing techniques to supplement its own capital in support of private and public sector projects.

In addition to providing direct loans to facilitate the financing of public sector projects, the EBRD jointly finances or cofinances on a parallel basis with other multilateral banks or organizations, bilateral financial institutions or development assistance agencies, and Export Credit Agencies (ECAs). The EBRD has developed a cofinancing technique with ECAs called "Export Credit Loan Arrangement Technique (ECLAT)". ECLAT permits the EBRD to tap into additional sources of funds for procurement of equipment and provides a vehicle to insure transactions between the commercial bank and the borrower. ECLAT allows for open procurement opportunities and establishes a direct lending relationship between commercial banks and its borrowers that would not be possible under conventional financing arrangements.

To mobilize additional sources of funds for private sector projects, the EBRD participates in loan syndications with other commercial banks; in this way, commercial banks can benefit from the EBRD's preferred creditor status, its knowledge of specific countries, and financial expertise. 
Contact: Noreen Doyle, Director

Credit and Syndications/External Financing

EBRD

One Exchange Square

London EC2A 2EH

England

Tel: $44-71 / 338-6196$

Fax: 44-71/338-6108

International Finance Corporation (IFC)

The IFC syndicates participations in loans and provides parallel and joint financing as a way to enable commercial banks to take on the risks of lending to developing countries and its clients access additional financing sources from international capital markets, and to raise long-term finance on reasonable terms on behalf of its clients.

Contact: Richard Parry

Syndications Department

IFC

Tel: $202 / 473-0398$

Fax: 202/334-8713

\section{D.3. In Country Sources}

Not applicable.

\section{E. TRADE FINANCE:}

\section{E.1. U.S. Government Sources}

\section{Export-Import Bank of the United States (EXIM)}

EXIM is currently closed in the Ukraine.

U.S. Small Business Administration (SBA)

SBA provides financial and business development assistance to assist small businesses in developing export markets. SBA offers the following programs: Regular Business Loan Program, Export Revolving Line of Credit Program, and the International Trade Loan Program. All these programs require the participation of an eligible commercial bank since they provide guarantees for loans.

Contact: U.S. Small Business Administration

Tel: $800 / \mathrm{U}-\mathrm{ASK}-\mathrm{SBA}$

Fax: 202/205-7064

\section{E.2. Multilateral Sources}

No known available sources. 


\section{E.3. In Country Sources}

Listed below are a sampling of Western commercial banks that are active in Ukraine:

Credit Lyonnais

2 Hreschatik Street

$252601 \mathrm{Kiev}$

Ukraine

Tel: 7-044/228-3025

Deutsche Bank

5 Rosa Luxemburg Street

Natsionalniy Hotel

$252021 \mathrm{Kiev}$

Ukraine

Tel: $7-044 / 290-7301$ or $291-8838$

Fax: 7-044/290-6266

Banque Nationale de Paris

5, Blvd. T. Chevchenko

$252002 \mathrm{Kiev}$

Ukraine

Tel: 7-044/229-1254

Fax: 7-044/228-5084

Dresdner Bank

12 Hospitalna Street

$252023 \mathrm{Kiev}$

Ukraine

Tel: 7-044/227-4694

Fax: 7-044/220-9070

First Ukrainian International Bank

3 Lypska Street

Natsionalniy Hotel, \#401

Kiev

Ukraine

Tel: 7-044/291-8741

Fax: 7-044/293-2064

Listed below are several Ukrainian banks:

Ukreximbank (State Export-Import Bank of Ukraine)

8 Kreshchatik Street

Kiev 1

252001 Ukraine

Tel: 7-044/226-2745

Fax: 7-044/229-8082 or 228-2776 
Ukrsotsbank

29 Kovpak Street

$252006 \mathrm{Kiev}$

Tel: 7-044/269-0836

Fax: 7-044/269-1307

Oshadbank Ukraina

7 Naukei Prospekt

$252028 \mathrm{Kiev}$

Ukraine

Tel: 7-044/265-3140

Fax: 7-044/264-9941

Bank Ukraina

8 Rilskly Lane

$254025 \mathrm{KieV}$

Ukraine

Tel: 7-044/244-1616

Fax: 7-044/229-0239

Prominvestbank of Ukraine

12 Shevchenko Lane

$252001 \mathrm{Kiev}-1$

Ukraine

Tel: 7-044/226-2032

Fax: 7-044/229-1456

West-Ukrainian Commercial Bank

67 Levitskogo Str.

290017 Lviv

Ukraine

Tel: 7-322/750-396

Fax: 7-322/750-551

Kiev Branch Office: 12 Frunze Str.

Kiev 252080

Tel: 7-044/417-1313

\section{F. TECHNICAL ASSISTANCE \& TRAINING:}

\section{F.1. U.S. Government Sources}

Nunn-Lugar Funds

The Nunn-Lugar Act of 1991 provided for defense conversion assistance to the NIS. The four republics that are recipients of defense conversion assistance are the Russian Federation, Belarus, Ukraine, and Kazakhstan. 
Nunn-Lugar is a $\$ 1.2$ billion program authorized by Congress for the funding of US assistance to republics of the former Soviet Union to (1) destroy nuclear, chemical, and other weapons; (2) safely transport, store, disable, and safeguard weapons in conjunction with their destruction; and (3) establish safeguards against their proliferation. The program authorized funds in $\$ 400$ million increments for $F Y$ 1992, 1993 and 1994 to the Department of Defense under the Defense Appropriations Act. It is anticipated that an additional $\$ 400$ million will be made available for FY 1995 . There are no definitive plans beyond 1995. The Nunn-Lugar Act has been recently renamed the "Cooperative Threat Reduction (CTR) Program". The Defense Nuclear Agency has been delegated the authority for program and financial management, procurement, and performance oversight. Support for Ukraine has been targeted for industry conversion and housing demobilization programs currently underway.

U.S. companies interested in bidding on contracts under the Nunn-Lugar program should track opportunities announced in the Commerce Business Daily or contact the Defense Nuclear Agency Hotline at $703 / 325-1175$.

\section{Eurasia Foundation}

Established with the support of USAID, the Eurasia Foundation is a private, non-profit organization that supports technical assistance, training, and educational and policy programs in the NIS. The Foundation's objectives are to support private sector development, public sector reform, and media and communications. Although the Foundation is looking to support approximately $\$ 16$ million in grants per year, the average size grant will remain in the range of $\$ 50,000$ to $\$ 75,000$ but may consider grants up to $\$ 150,000$. Grant proposals must demonstrate support of private sector development and/or democratic institution building; indigenous institution building and strengthening; and transfer, adaptation, or development of local skills. Letters of inquiry regarding project proposals should be addressed to the contact below.

Contact: Program Office

Eurasia Foundation

1527 New Hampshire Avenue, NW

Washington, DC 20036

\section{U.S. Agency for International Development (USAID)}

\section{- Energy Efficiency and Market Reform}

USAID established a NIS Task Force in January 1992 to support technical and humanitarian assistance programs in NIS region. Approximately $\$ 235$ million for FY92 and $\$ 410$ million for FY93 was authorized under the Freedom Support Act. In FY94, USAID budgeted $\$ 215$ million for energy sector projects in the NIS. Approximately $\$ 75$ was budgeted for FY95. The project has four components: efficiency and performance improvement; production and delivery systems; pricing, policy, and institutional reform; and nuclear power plant safety and regulation.

USAID has supported numerous activities in Ukraine to date: made energy efficiency improvements in district heating; set up energy efficiency center in Kiev; weatherized and metered apartment blocks and rehabilitated district heating system in Bila Tsirka, which is to be implemented in conjunction with the World Banks' Global Environmental Facility; tested U.S. clean coal combustion technologies; procured critically needed resins for a combined heat and power plant in Kiev; designed coal bed methane drilling project; advised on management and safety of coal mines in the Donbass region; established energy industry partnership program between U.S. and Ukrainian utilities; led Presidential Decree on restructuring the utility industry to promote competition and efficiency; participated in a 
joint team inspection with NRC at a nuclear power plant; and developed Ukrainian nuclear plant inspection procedures and performance assessments.

New initiatives underway are activities to launch industrial energy efficiency programs on electricity demand side management; equip combined heat and power plants with energy savings instrumentation; interpretation of oil and gas seismic data; establish electricity generation companies and regulatory bodies; upgrade nuclear and fire safety systems in nuclear plants; and use of computer-based software and simulators in nuclear plants.

All USAID programs are administered in conjunction with the USAID mission in Ukraine.

Contact: Robert Ichord, Director

Office of Energy and Infrastructure

Bureau for Europe \& NIS

USAID

Washington, DC 20453

Tel: 202/647-8274

Fax: 202/647-6962

-or-

Jim Osborn or Gregory Huger

USAID Mission

Tel: 7-044/220-5589

Fax: 7-044/220-7079

\section{- International Executive Service Corps}

$\$ 1$ million in funds were provided to USAID under the Foreign Appropriations Act of 1994 to support the International Executive Service Corps (IESC). USAID provided a $\$ 1$ million grant to IESC in FY 1992 to support general industry conversion activities. Technical advisors were placed in 4 cities: Nizhniy Novgorod and Yekaterinburg, Russia; Kharkhiv, Ukraine; and Almaty, Kazakhstan. This program will run until the end of FY 1994. DOD will continue to support this effort in FY 1995 providing the IESC with $\$ 1$ million per year.

Contact: Richard Shriver, Vice President

IESC

Stamford Harbor Park

333 Ludlow Street

Stamford, CT 06902

Tel: 203/967-6342

Fax: 203/359-3233

- Energy Partnership Program

Through the support of USAID, the U.S. Energy Association launched the Utility Partnership Program in July 1992. The Partnership Program links U.S. utilities with those in the NIS region to form industry partnerships between U.S. electric power and natural gas utilities and associations with their counterparts in the NIS. The objective of the program is to enable energy executives to work together in reshaping the NIS energy industry by introducing new concepts and industry structure and 
management under a free enterprise system. The areas of focus are industry restructuring, general utility management, energy efficiency, and the environment. In Ukraine, there is currently an energy partnership between Pennsylvania Power \& Light and Kievenergo.

Contact: William Polen, Program Manager

U.S. Energy Association

1620 Eye Street, NW, Suite 1000

Washington, DC 20006

Tel: 202/331-0415

Fax: 202/659-0578

\section{U.S. Department of Agriculture (USDA)}

USDA provides export credit guarantees, export subsidies, and food aid throughout the NIS region to facilitate commodity exports. USDA also has a number of on-going technical assistance programs to provide support for agricultural reform and environmentally-sound agricultural practices.

Contact: DeAndra Beck

Director, CEE \& NIS Programs

U.S. Department of Agriculture

South Building Room 3214

Washington, DC $20250-4300$

Tel: $202 / 720-8875$

Fax: 202/690-0892

Special American Business Internship Training Program (SABIT)

Through the support of USAID, SABIT provides support for the exchange of senior NIS scientists and managers to come to the U.S. for a three to six month training internship with U.S. companies. The SABIT program provides NIS managers and scientists with hands-on experience in working in the U.S. to familiarize them with U.S products, services, and management techniques in their field of expertise. Training NIS scientists in U.S. companies allow them to apply their skills to peaceful research and development and expose them to the role of scientific research in a market cconomy. SABIT focuses on the agribusiness, defense conversion, energy, environment, medical, telecommunications, financial services, transportation, and medical/pharmaceutical/health care management areas. SABIT grants to U.S. firms help to defray the cost of the internships. This program is managed by the U.S. Department of Commerce.

\section{Contact: Liesel Duhon-Winski}

SABIT

U.S. Department of Commerce

Washington, DC 20230

Tel: 202/482-0073

Fax: 202/482-2443

Consortia of American Businesses in the Newly Independent States (CABNIS)

CABNIS has provided grants to trade organizations to establish a non-profit consortia to assist small- and medium-sized companies in key sectors develop a commercial presence in the NIS region. The consortia provides member companies with export information, trade leads, marketing and promotional services. This effort is managed by the U.S. Department of Commerce. 
Contact: Eric Cimon

U.S. Department of Commerce

International Trade Administration

Washington, DC 20230

Tel: $202 / 482-5004$

Fax: 202/482-1790

\section{F.2. Multilateral Sources}

\section{World Bank}

\section{- Energy Efficiency Cross-Support Team}

In addition to the Ukraine team and energy division of the World Bank, the Industrial and Energy Department of the Central Vice-Presidency for Finance and Private Sector Development of the World Bank provides cross-support for sectoral and geographic departments of the Bank. Cross-support is provided for project lending, institutional development, and technical assistance related to energy efficiency and conservation, and rural, household, and renewable energy initiatives. This crosssupport team can provide implementation support for energy efficiency components of on-going Bank project lending and technical assistance as well as assess and monitor state-of-the-art technology and energy management practices for key end-user sectors.

\section{Contact: Karl Jechoutek, Division Chief} Industry and Energy Department

Vice Presidency for Finance and Private Sector Devclopment World Bank Washington, DC 20433

Tel: 202/458-6391 Fax: 202/477-0542

\section{F.3. In Country Sources}

\section{ARENA-ECO (Ukrainian Center for Energy Efficiency and Environmental Protection)}

ARENA-ECO is a non-profit, non-governmental organization established in 1994 in partnership with Battelle, Pacific Northwest Laboratory, Institute of Energy Saving Problems and the National Academy of Sciences of Ukraine. The main objectives of ARENA-ECO are to provide energy efficiency and environmental protection services and audits, foster the implementation of advanced technologies and distribution of equipment, and provide education and training activities and informational services.

Contact: Nikolai Raptsoun

ARENA-ECO

The Ukrainian Center for Energy Efficiency and Ecology

PO Box 53

$252150 \mathrm{Kiev}$

Ukraine

Tel \& Fax: 7-044/416-2358 


\section{G. INDEX}

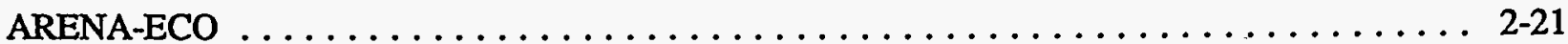

Bank Ukraina . . . . . . . . . . . . . . . . . . . . . . . . . . 2-17

Banque Nationale de Paris $\ldots \ldots \ldots \ldots \ldots \ldots \ldots \ldots \ldots \ldots \ldots \ldots \ldots . \ldots \ldots \ldots$

Committee on Energy Efficiency Commerce and Trade (COEECT) . . . . . . . . . . . . . . 2-2

Committee on Renewable Energy Commerce and Trade (CORECT) . . . . . . . . . . . . 2-2

Consortia of American Businesses in the NIS (CABNIS) . . . . . . . . . . . . 2-20

Credit Lyonnais . . . . . . . . . . . . . . . . . . . . . . . . . 2-16

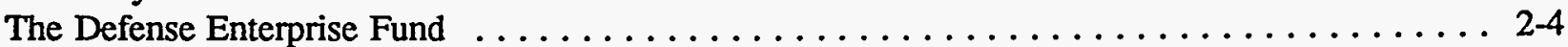

Deutsche Bank .................................. 2-16

Dresdner Bank ................................. 2-16

Environmental Enterprises Assistance Fund (EEAF) $\ldots \ldots \ldots \ldots \ldots \ldots \ldots \ldots \ldots \ldots \ldots$

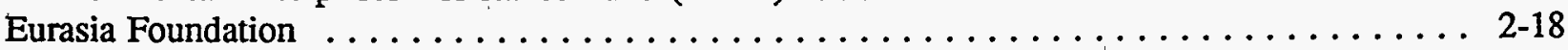

European Bank for Reconstruction and Development (EBRD) $\ldots \ldots \ldots \ldots \ldots \ldots \ldots \ldots$ 2-3,9,14

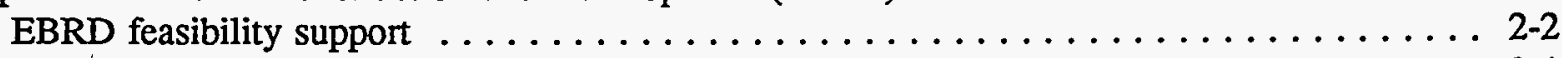

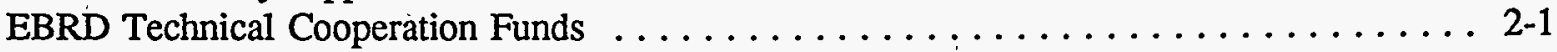

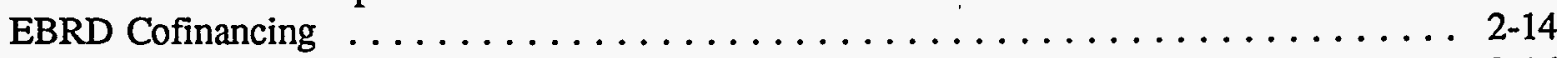

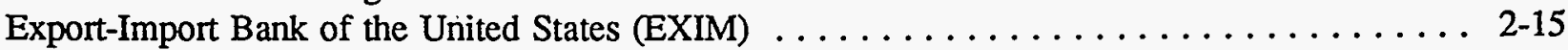

First NIS Regional Fund $\ldots \ldots \ldots \ldots \ldots \ldots \ldots \ldots \ldots \ldots \ldots \ldots \ldots \ldots \ldots$

First Russian Frontiers Trust PLC $\ldots \ldots \ldots \ldots \ldots \ldots \ldots \ldots \ldots \ldots \ldots \ldots \ldots \ldots \ldots \ldots \ldots$

First Ukrainian International Bank . . . . . . . . . . . . . . . . . . $2-16$

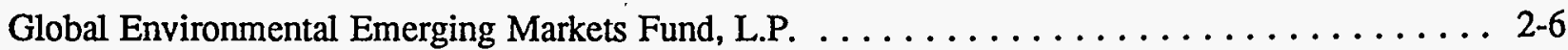

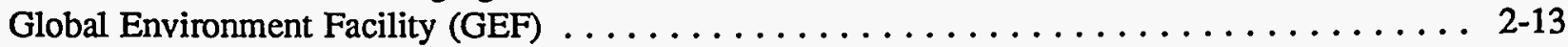

International Bank for Reconstruction and Development (WORLD BANK) $\ldots \ldots \ldots \ldots$. . . 2 2,14

International Executive Service Corps . . . . . . . . . . . . . . . . . . . . . . . . . . 2-20

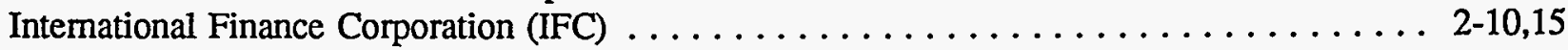

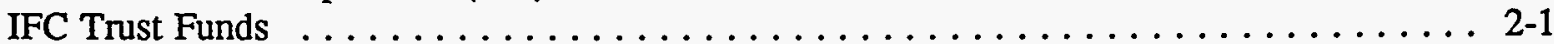

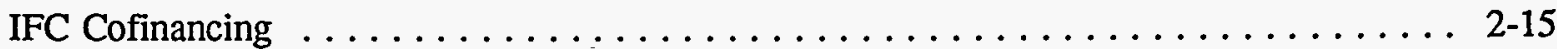

Intemational Fund for Renewable Energy and Energy Efficiency (IFREE). . . . . . . . . . 2-1

Junction Investors Ltd. (JIL) . . . . . . . . . . . . . . . . . . . . . . . . . . . . . 2-8

NCH Advisors . . . . . . . . . . . . . . . . . . . . . . . . . $2-8$

New Europe East Investment Fund $\ldots \ldots \ldots \ldots \ldots \ldots \ldots \ldots \ldots \ldots \ldots \ldots \ldots \ldots \ldots \ldots$

Newstar Fund . . . . . . . . . . . . . . . . . . . . . . . . . . . . . 2-9

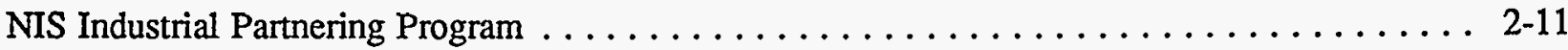

Nuclear Safety Account . . . . . . . . . . . . . . . . . . . . . . . . 2-12

Nunn-Lugar Funds . . . . . . . . . . . . . . . . . . . . . . . . 2-17

Oshadbank Ukraina . . . . . . . . . . . . . . . . . . . . . . $2-17$

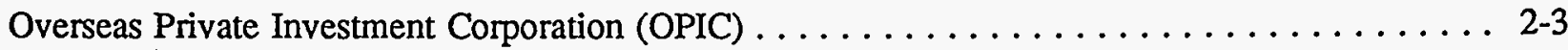

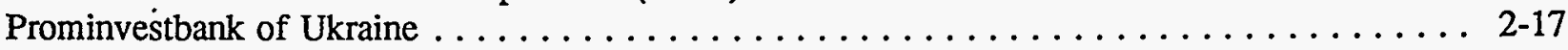

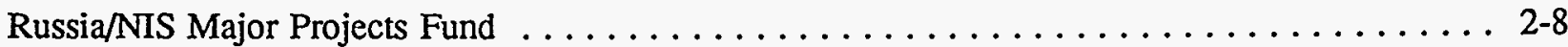

Russia Partners Fund . . . . . . . . . . . . . . . . . . . . . . . 2-7

Special American Business Internship Training Program (SABIT) . . . . . . . . . . 2-20

U.S. Agency for International Development (USAID) $\ldots \ldots \ldots \ldots \ldots \ldots \ldots \ldots \ldots$. . . . . . . . . .

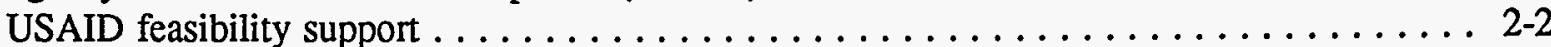

USAID NIS Programs . . . . . . . . . . . . . . . . . . . . . 2-18,19

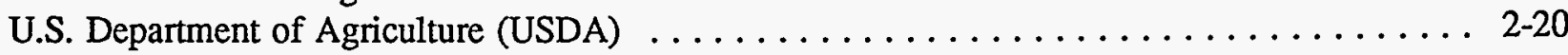


U.S. Small Business Administration (SBA) $\ldots \ldots \ldots \ldots \ldots \ldots \ldots \ldots \ldots \ldots \ldots \ldots$

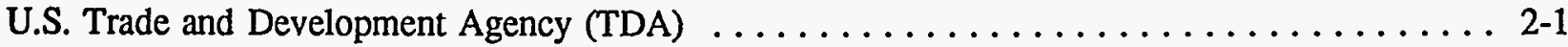

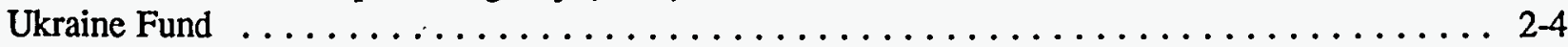

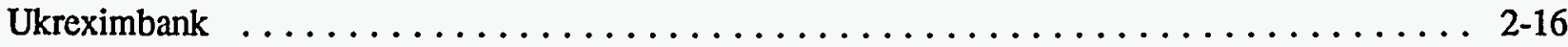

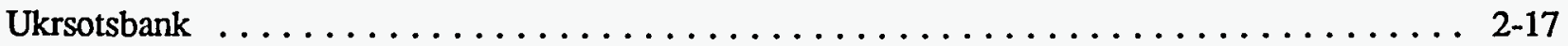

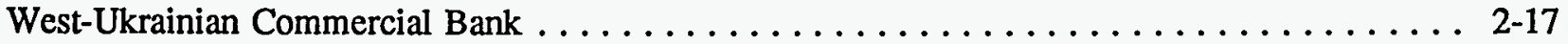

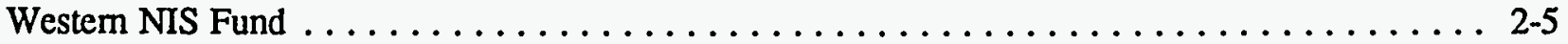

World Bank . . . . . . . . . . . . . . . . . . . . . . . . . . . . 2-21

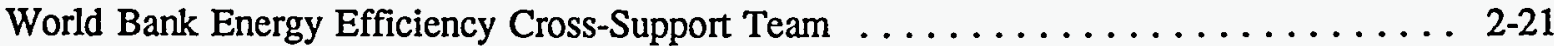

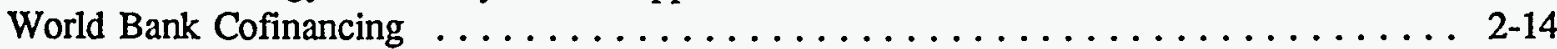



3. CHINA 


\section{A. FEASIBILITY FINANCING:}

\section{A.1. U.S. Government Sources}

\section{U.S. Trade and Development Agency (TDA)}

TDA is not authorized to provide grant assistance in China

Export-Import Bank's (EXIM) Engineering Multiplier Program

EXIM's Engineering Multiplier Program funds project-related feasibility studies and pre-construction design and engineering services. Under this program, EXIM offers fixed-rate loans and guarantees to foreign buyers of these services. This program is designed to generate additional overseas sales of U.S. goods and services since the foreign buyer is more likely to order U.S. equipment and services for a construction project on which U.S. engineers, designers, and architects performed the work. Up to $\$ 10$ million in the value of U.S. exports are covered. Projects supported under this program must generate subsequent U.S. export orders valued at no less than $\$ 10$ million or double the original export contract, whichever is greater. Direct loans are extended for up to 85 percent of the U.S. export value. The foreign buyer must match that with a 15 percent cash payment to the U.S. company. EXIM also offers guarantees for commercial financing for approved project-related local costs in the host country of up to 15 percent of the U.S. contract cost. If the project goes forward with U.S. goods and services, EXIM may extend a loan and/or guarantee, in which case the loan can then be rolled into the later financing.

Contact: James Mahoney, Vice President

Engineering Division

Export-Import Bank of the United States

811 Vermont Avenue, NW, Room 1167

Washington, DC 20571

Tel: 202/565-3571

Fax: 202/565-3584

Committee on Renewable Energy Commerce and Trade (CORECT)

CORECT is an interagency working group comprised of representatives from 14 U.S. Federal government agencies, chaired by the U.S. Department of Energy. CORECT works closely with the U.S. Export Council for Renewable Energy (US/ECRE), an industry consortium of seven renewable energy trade associations, to promote renewable energy exports in international markets and ensure that renewable energy technologies and applications are integrated in development projects.

Contact: Ronald Bowes, Director

Office of Technical Assistance

Energy Efficiency and Renewable Energy

U.S. Department of Energy

1000 Independence Avenue, SW, Room 5E-036

Washington, DC 20585

Tel: 202/586-2959

Fax: 202/586-1605 
Committee on Energy Efficiency Commerce and Trade (COEECT)

COEECT is an interagency working group comprised of representatives from 14 U.S. Federal government agencies, chaired by the U.S. Department of Energy. COEECT works closely with the Energy Efficiency Export Council to undertake market assessment for energy efficiency products and services, identify project financing from federal and multilateral institutions, and address the specific needs of the energy efficiency products and services industry.

Contact: Ronald Bowes, Director

Office of Technical Assistance

Energy Efficiency and Renewable Energy

U.S. Department of Energy

1000 Independence Avenue, SW, Room 5E-036

Washington, DC 20585

Tel: 202/586-2959

Fax: 202/586-1605

\section{A.2. Multilateral Sources}

\section{Asian Development Bank}

ADB does perform pre-investment and/or feasibility studies usually for projects in which it is interested in investing. Interested parties should track the ADB procurement notice bulletins. To obtain information on $\mathrm{ADB}$ procurement opportunities, contact the representatives below.

Contact: Janet Thomas, Procurement Liaison

Asian Development Bank

\#6 ADB Avenue

1501 Madaluyuong Metro

Manila Philippines

Tel: $011-632 / 890-9364$

Fax:011-632/890-9713

-or-

Mary Alice Healy

U.S. Department of Commerce

Room 1107

Washington, DC 20230

Tel: $202 / 482-4333$

Fax: 202/273-0927

\section{A.3. In Country Sources}

No known available sources. 


\section{B. PROJECT FINANCE - PRIVATE SECTOR:}

\section{B.1. U.S. Government Sources}

\section{Overseas Private Investment Corporation (OPIC)}

OPIC is not authorized to offer financing programs in China

\section{Export-Import Bank's Project Finance Program}

EXIM Bank recently launched a new program to finance projects that are dependent solely on the project cash flow of the particular project for repayment. Projects under this program can not rely on sovereign guarantees to assure repayment as is normally required under typical EXIM Bank export credit packages. Under this program, EXIM offers (1) allowance of up to 15 percent foreign content in the US package; (2) financing of interest accrued during construction related to the EXIM Bank financing facilities; (3) financing of host country local costs of up to 15 percent of the US contract value; (4) maximum repayment term allowed under the OECD guidelines; (5) no minimum/maximum limitations on project size; (6) flexible coverage and equity arrangements; (7) exposure fee commensurate with risk; and (8) rapid application processing.

Contact: Glen Matsumoto, Vice President

Project Finance Division

Export-Import Bank of the United States

811 Vermont Avenue, NW

Washington, DC 20571

Tel: 202/565-3690

Fax: 202/565-3695

The investment funds listed below have been capitalized primarily with funds from U.S. government and multilateral organizations:

AIG Asian Infrastructure Fund

The AIG Asian Infrastructure Fund makes equity and convertible debt investments in private infrastructure and related projects in priority sectors in China and other countries in the Asia Pacific region. The Fund is capitalized at US $\$ 1,086$ million. The core investors are the American International Group (AIG), the Singapore Government Investment Companies, US pension funds, and the Brunei government 35 percent to 50 percent of the Fund is expected to be invested in China. The balance will be dedicated to investments in Indonesia, Malaysia, the Philippines, Taiwan, Thailand, and other Asian countries. The Fund is prepared to invest in greenfield, expansion, privatizations, pre-IPO projects, and participate in cofinancing opportunities. Typical investments range from US\$10 to US\$100 million for primary projects and US $\$ 2$ million to US $\$ 20$ million for secondary projects. The Fund may invest up to US\$100 million in any single project but will participate as a minority stockholder. Targeted sectors are power and related energy, telecommunications, transportation, natural resource development, petrochemical, environment, and infrastructure related facilities. 
Contact in U.S.:

AIG-Asian Infrastructure Fund

c/o Emerging Markets Corporation

Donald C. Roth, Managing Director

Mumtaz Khan, Senior Vice President - Direct Investments

1828 L Street, N.W., Suite 900

Washington, D.C. 20036

Tel: 202/331-9051

Fax: 202/331-9250

Contact in Hong Kong: Dr. Wan-Lin Kiang

Executive Director, Infrastructure Group

AIG-Asian Infrastructure Fund

AIA Building, 14/F

1 Stubbs Road

Hong Kong

Tel: 011-852/832-1993

Fax:011-852/893-9530

Contact in Singapore: Mr. Ho Soo Ching, General Manager

Singa Infrastructure Management Pte. Ltd.

250 North Bridge Road

\#13-01, Raffles City Tower

Singapore 0617 Singapore

Telephone: 011-65/330-3992

Fax: $\quad 011-65 / 330-8590$

Direct: $\quad 011-65 / 330-8551$

Peregrine Asian Infrastructure Fund

The Peregrine Fund will be capitalized at approximately US $\$ 1$ billion and is expected to close sometime between May and mid-July, 1995. The International Finance Corporation, Asian Development Bank, and the Asian Infrastructure Development Fund Ltd are the initial investors of the Fund and Peregrine Investments and Frank Russell Investments are its sponsors. The main objective of the Fund is to achieve long-term capital appreciation through infrastructure investments in Asia, including China. The Fund will invest in non-listed equity or equity linked securities of entities that are engaged in the development, ownership, or operation of infrastructure facilities. Target sectors are primarily power, transportation, and telecommunications.

Contact: William Liley

Asian Infrastructure Fund Management Company Ltd.

16-18 Queen's Road Central

New World Tower

Hong Kong

Tel: 011-852/2825-1169

Fax: 011-852/2845-0786

-or- 
Peregrine Brokerage Inc.

780 Third Avenue, Suite 2601

New York, NY 10017

Tel: $212 / 593-5920$

Fax: 212/593-5932

Global Power Investments Fund

GE Capital Corporation and Soros Fund Management established Global Power Investments Fund, a new venture capital fund, which will make subordinated debt and equity investments in privately-owned electric power generating facilities in emerging markets, including China. The Fund is capitalized at $\$ 500$ million with initial capital contributions by GE Capital, Soros Fund Management, Quantum Industrial Holdings, and the International Finance Corporation (IFC). Additional capital will be raised to reach a total capitalization target of at least $\$ 2.5$ billion. The Fund will primarily invest in the new construction of power plants (gas-fired, coal-fired, and possibly cogeneration), although it may invest in existing facilities. Global Power Investments will look to projects that use commercially-viable, proven technologies. GE Capital will take the lead on identifying projects in the field, providing the analysis of risks and returns, negotiating the terms of transaction, and managing the portfolio of investments. Soros Fund and the IFC will provide investment advisory services and assist in making investment decisions on behalf of the Fund.

Contact: Dick Fowler

GE Capital Corporation

1600 Summer Street, 6th Floor

Stamford, CT 06927

Tel: 203/357-4385

Fax: 203/357-6289

-or-

Carl Bongarten

GE Capital Corporation - Hong Kong

Tel: $011-852 / 2847-8160$

Fax: 011-852/2847-8198

\section{Global Emerging Markets Leasing Fund}

With capital contributions from the IFC, an Emerging Markets Fund has been proposed as a closed-ended investment fund that would be managed by the Banque Nationale de Paris, France. The Fund would support cross-border leveraged leasing transactions originating in France with several developing countries, including China, Indonesia, Malaysia, Pakistan, Russia, Thailand, and Turkey. The Fund would help develop cross-border leasing as a source of long-term foreign currency debt finance for emerging markets and help meet the demand for financing from emerging market lessees. No contact information is available as the Fund is not as yet in operation.

\section{B.2. Multilateral Sources}

\section{International Finance Corporation (IFC)}

IFC, a member of the World Bank, is the largest source of direct financing for private sector projects in developing countries, including China. Unlike the World Bank, IFC lends directly to private companies and does not request guarantees from host-country governments. It can provide loans, make equity 
investments in private businesses, and mobilize additional loan and equity financing in international financial markets through syndication efforts. Although IFC invests and lends on market terms, it finances projects unable to obtain sufficient funding on reasonable terms from other sources. Increasingly, the IFC is working through intermediary financial facilities in order to support smaller scale projects and supporting co-finance arrangements with the World Bank (GEF) and EBRD.

Loans and equity investments are usually limited to no more than 25 percent of project cost. IFC's minimum investment project support is $\$ 10$ million. Funds may be used for foreign or local expenditures related to overall project costs, i.e, fixed assets, permanent working capital, interest during construction, and pre-operating cost. IFC can invest up to 35 percent of the share capital as long as it is not the major shareholder. It turns over its equity often by sale to local investors when the investment has matured. Both fixed and variable rate loans are offered; rates are determined on a commercial basis. Terms normally run from seven to twelve years.

Contact for China:

Harold Rosen, Acting Director

Asia Department, Division II

IFC

1850 Eye Street, NW, Room 11-063

Washington, DC 20433

Tel: 202/473-8841

Fax: 202/676-0820

Contact for Energy \& Environment: Martyn Riddle, Manager

Environmental Unit

International Finance Corporation

1850 Eye Street, NW

Washington, DC 20433

Tel: 202/473-0661

Fax: 202/676-9495

\section{B.3. In Country Sources}

No known available sources.

\section{PROJECT FINANCE - PUBLIC SECTOR:}

\section{C.1. U.S. Government Sources}

No known available sources. 


\section{C.2. Multilateral Sources}

\section{Asian Development Bank (ADB)}

Headquartered in Manila, the Philippines, the Asian Development Bank is a development finance institution whose mandate is to promote the economic and social progress of its 53 development member countries in the Asian and Pacific region. On behalf of its member countries, the Bank aims to (1) make loans and equity investments to enhance their economic and social development; (2) promote investment of public and private capital to meet their developmental goals; (3) provide technical assistance for the preparation and execution of their development projects and programs, and advisory services; and (4) respond to requests for assistance in coordinating their development policies and plans.

Contact for China: Bruce Murray, Programs Manger

Division I, Mongolia, China, Taipei

Programs Department East

Tel: 011-632/632-6247

Fax:011-632/636-2381

Contact for Energy: Kazu Sakai, Senior Project Economist

Energy Division

Infrastructure, Energy and Financial Sectors Department

Tel: $011-632 / 632-6363$

Fax:011-632/636-2422

International Bank for Reconstruction and Development (WORLD BANK)

The World Bank, a multilateral lending agency, is the largest source of financial and technical assistance to the public sector in developing countries. The Bank also makes policy-oriented structural and sectoral adjustment loans to support market-oriented institutional reforms. The Bank lends to member governments for public sector, development projects, not to the private sector. The Bank affiliate that lends to the private sector is the IFC. Loans are made only to governments or to agencies that can obtain a government guarantee for repayment. Bank funds are used by member governments to import food and equipment, fund project construction, and obtain consultant services. Interest rates on Bank loans are set a half a percentage point above the Bank's average cost of borrowing and repayment terms are normally twelve to fifteen years, including a three to five year grace period.

China has been the leading recipient of World Bank funds for the past three fiscal years. For the fiscal year ending June 30, 1994, the World Bank approved more than $\$ 3$ billion for 14 projects in the areas of agriculture, energy, transport infrastructure, industry, education, and technological modemization. Currently, there are about 40 projects in the Bank pipeline for China, of which almost half are in the transport and energy sectors. Massive power projects, both thermal and hydroelectric are the main targets of energy funding. For future lending, the World Bank will aim to channel its funding to support programs on environmental protection, poverty reduction, and economic reform. 
Contact for China:

Contact for Energy:

\author{
Mr. Zafer Ecevit, Division Chief \\ Country Operations Division, China and Mongolia \\ World Bank \\ 1818 H Street, NW \\ Room MC-7321 \\ Washington, DC 20433 \\ Tel: $202 / 458-4072$ \\ Fax: 202/522-1556
}

Richard Newfarmer, Division Chicf

Industry \& Encrgy Division, China and Mongolia

The World Bank

1818 H Street, NW

Room D7-111

Washington, DC 20433

Tel: 202/473-1978

Fax: 202/522-1784

-or-

Bob Taylor

Senior Energy Economist

The World Bank

Room D7-087

Washington, DC 20433

Tel: $202 / 458-2446$

Fax: 202/522-1784

Resident Representative: Pieter P. Bottelier

Chicf, Resident Mission

World Bank

P.O. Box 802

Beijing 100830,China

Tel: 011-861/851-2227

Fax:011-861/852-4140

Global Environment Facility (GEF)

Established in 1990, GEF provides grants for investment projects and technical assistance to assist developing countries to address four main global (transboundary) environmental problems: global warming, pollution of international waters, destruction of biological diversity, and depletion of the ozone layer. GEF is co-managed by the World Bank, U.N. Devclopment Programme, and the U.N. Environmental Programme. To qualify for funding under the GEF, projects must be innovative, demonstrate the effectiveness of a particular technology or approach, and fall into one of the four priority areas. GEF funding is possible if the project offers substantial global benefits, but is unlikely to be viable without some concessional funding or if a project is economically viable but requires supplemental finance to bring about global benefits. 
GEF projects can either be free-standing, components of World Bank projects, or pass through the IFC to support private sector ventures that have both important demonstration benefits and host government endorsement. Free-standing GEF projects are limited to $\$ 10$ million, and GEF components of World Bank projects must not exceed $\$ 30$ million. GEF funds can leverage regular Bank projects by paying the additional cost of incorporating environmentally benign technologies-in Bank-supported projects. GEF funds would cover the difference in cost between what the host country is willing to pay and the cost of the benign technology. Use of GEF funds through the IFC can be used if the sponsor/lender could not otherwise underwrite the risk under prevailing market conditions; funds cannot be used to avert normal commercial risks.

Contact: Christina Kimes, Regional Coordinator

Global Environment Coordination Division

Latin American \& East Asia

The World Bank

Room S-2133

Washington, DC 20433

Tel: 202/473-3689

Fax: 202/522-3256

\section{C.3. In Country Sources}

Three policy banks have been recently established to provide public sector financing. Contact information is not as yet available.

State Development Bank (SDBC)

This bank will be responsible for financing key public construction and infrastructure projects in basic, emerging "pillar" industries (such as automobiles and electronics), and other state priority projects in forestry and environmental protection through debt instruments, e.g., loans. Equity operations will be handled by a State Development Investment Corporation to be established through the merger of existing state investment corporations.

\section{Agricultural Development Bank of China (ADBC)}

The Agricultural Development Bank will provide financing for state procurement of agricultural products, agricultural development, and social infrastructure development.

\section{Export-Import Bank of China (EIB)}

The Export-Import Bank is to provide export and import credits for large-scale machinery and electronics.

\section{COFINANCING:}

\section{D.1. U.S. Government Sources}

Not applicable. 


\section{D.2. Multilateral Sources}

International Bank for Reconstruction and Development (World Bank)

Although the Bank mainly lends to governments and government agencies, it can also provide guarantees to commercial lenders for public and private sector projects. The Bank's guarantee program currently covers loans totalling $\$ 1$ billion. As a way to attract private sector capital and encourage direct foreign investments in developing countries, the Bank's Executive Directors approved a proposal making guarantees a mainstream instrument of Bank operations in September 1994. There are two types of guarantees offered: (1) partial risk guarantee that covers non-performance of sovereign contractual obligations or other contractual non-performance problems in a project and (2) partial credit guarantee which extends maturities beyond what private lenders could otherwise provide.

By covering risks that the market would not bear, the Bank's guarantee program helps reduce the cost of financing projects by guaranteeing against contractual non-performance, offers flexibility to structure project financing by extending maturities, and attracts private sources of capital by sharing risks of undertaking infrastructure projects in developing countries.

Contact: Nina Shapiro, Manager

Project Finance Group

CoFinancing and Financial Advisory Department

World Bank

Tel: 202/473-1650

Fax: 202/477-0218

\section{Asian Development Bank (ADB)}

The ADB syndicates participations in loans and provides parallel and joint financing as a way to enable commercial banks to take on the risks of lending to developing countries and its clients access additional financing sources from international capital markets, and to raise long-term finance on reasonable terms on behalf of its clients.

\section{Contact: Eikki Jappinen, Manager \\ Cofinance Unit \\ Asian Development Bank \\ Tel: $011-632 / 632-6314$ \\ Fax:011-632/636-2456}

International Finance Corporation (IFC)

The IFC syndicates participations in loans and provides parallel and joint financing as a way to enable commercial banks to take on the risks of lending to developing countries and its clients access additional financing sources from international capital markets, and to raise long-term finance on reasonable terms on behalf of its clients.

Contact: Richard Parry

Syndications Department

IFC

Tel: 202/473-0398

Fax:202/334-8713 


\section{D.3. In Country Sources}

Not applicable.

\section{E. TRADE FINANCE:}

\section{E.1. U.S. Government Sources}

Export-Import Bank of the United States (EXIM)

EXIM is an independent, U.S. government agency that provides support for U.S. exports through shortand medium-term export credit insurance, medium- and long-term loan guarantees, medium- and long-term direct and intermediary loans, working capital guarantees, and project financing. EXIM will consider alternative energy projects in energy efficiency and renewable energy that incorporate geothermal, solar, wind, hydroelectric, cogeneration and biomass technologies.

EXIM will only help finance exports of U.S. goods and services containing at least 50 percent U.S. content. The entire value of the shipment is covered under short-term export credit programs, while 100 percent of the U.S. content of the shipment is covered under medium- and long-term programs provided that EXIM's support does not exceed 85 percent of the export price. EXIM's short-term programs cover up to 360 days, medium-term programs cover up to five years, and long-term programs cover twelve years.

For China, EXIM provides (1) short-term, medium-term, and long-term loans and guarantees and (2) limited recourse project financing (for (2) see description under "Project Finance - Private Sector"). For medium-term and long-term loans and guarantees, EXIM requires that the Bank of China, China International Trust and Investment Corporation (CITIC) or People's Construction Bank of China is willing to serve as an obligor or guarantor of the project. EXIM will consider guarantee arrangements with other Chinese financial institutions.

Financing of exports of equipment would be covered under EXIM's long-term loan and guarantee program (financing up to ten years) or under its medium-term loan and guarantee program (financing up to five years, possibly seven in exceptional cases). Under EXIM short-term credit insurance program, exports of consumer goods, spare parts, raw materials (up to 180 days) and bulk agricultural commodities and quasicapital goods (up to 360 days) would be covered.

EXIM financing may not be used to support the sales of defense articles and services to any country for offensive or defensive military purposes, except for anti-narcotics purposes under limited circumstances.

Contact: Frank Wilson, Senior Business Development Officer Business Development Office

EXIM

Tel: $202 / 565-3900$

Fax: 202/565-3931 


\section{E.2. Multilateral Sources}

Trade finance is primarily through cofinancing export credit facilities available through multilateral institutions.

\section{Other Sources may include:}

The Export-Import Bank of Japan (JEXIM)

The Export-Import Bank of Japan (JEXIM) is an independent governmental financial institution of Japan. The mandate of JEXIM is to provide a wide range of financial services to supplement and encourage financing by commercial banks and other financial institutions and to foster Japanese overseas investment and international financial cooperation for economic development worldwide. JEXIM is very aggressive in cofinancing deals with international development and commercial banks and has been quite active in the Chinese market. Of particular interest to U.S. companies are untied loans available under JEXIM's "Funds for Development" initiative. This $\$ 120$ billion initiative was launched in June, 1993 to promote economic progress in developing countries through funding for Japanese exporters or project sponsors to finance projects in developing countries. However, financing is also provided to U.S. and other foreign

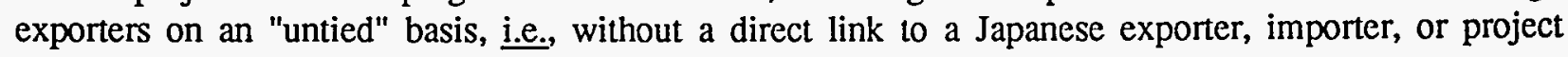
sponsor.

Contact in U.S.: $\quad$ Export-Import Bank of Japan

2000 Pennsylvania Avenue, NW

Washington, DC

Tel: 202/331-8547

Fax: 202/775-1990

Contact in China: Export-Import Bank of Japan

Representative Office

Dongyilou Qianmen Dongdajie 23

Beijing 100006 China

Tel: $\quad 011-861 / 512-5119-6617$

Fax: 011-861/512-0572

Telex: 85-211212

\section{E.3. In Country Sources}

Below is a list of leading Chinese banks headquartered in Beijing:*

The Agricultural Bank of China

Head Office

25 Fu Xing Road

Beijing 100036

Tel: $011-861 / 821-6807$

Fax:011-861/821-6807

Telex: 22017 ABC CN

Swift: Aboc CN BJ 
International Department

40 Fu Cheng Road

3/F Yulong Hotel

Beijing 100046

Tel: 011-861/841 3128

Fax: 011-861/841 6682 (AUTO)

Telex: 22060 abci cn

Bank of China

Head Office

Bank of China Building

Fuchengmen Nei Dajie 410

Beijing 100818

Tel: 011-861/601-6688

Fax: 011-861/601-6869

.Telex: 2254 BCHO CN

Swift: BKCH CN BJ

City Branch

19 Dong An Men Street

Beijing 100006

Tel: 011-861/519-9114

Fax:011-861/512-2177

Telex: 210662 BOCCB CN

China Investment Bank

B-11A, Fuxing Road

Beijing

Tel: $011-861 / 851-5900$

Fax: 011-861/801-6088

Telex: 22357 CIB CN

CITIC Industrial Bank

6, Xinyuannanlu

Chaoyang District

Beijing

Tel: 011-861/466-0088

Fax: 011-861/466-1059

Telex: 22987 CITIC CN

Guangdong Development Bank 2/8/10,Guangdong Trade Center 1, Qiyi Road

Guangzhou

Tel: 011-8602/332-1398

Fax:011-8602/334-9194 
Shenzhen Development Bank

45, Baoan Nanlu

Shenzhen, Guangdong

Tel: 011-86755/556-2114

Fax:011-86755/556-2117

The Industrial \& Commercial Bank of China

Head Office

13 Cuiwei Road

Haidian District

Beijing 100036

Tel: $011-861 / 821-7156$ or $821-7782$

International Department

Tel: $011-861 / 821-7908$ or $821-7925$

Fax:011-861/821-7920

Telex: 22770 ICBHO CN

Swift: ICBK CN BJ

People's Construction Bank of China

12c Fuxing Road

Beijing

Tel: 011-861/801-5303

Fax: 011-861/801-5328

Telex: $222977 \mathrm{pcbc} \mathrm{cn}$

*This list does not represent a complete listing of Chinese banks headquartered in Beijing; it is meant to highlight those leading Chinese banks most active in project financing and loan syndications.

Below is a list of U.S. and foreign investment and commercial banks that are active in the Chinese market:

\section{ABN AMRO Bank NV}

Representative Office

Room 3306, Jing Guang Center

Hu Jia Lou, Chaoyang Distrist

Beijing 100020

Tel: 011-861/501-2055

Fax:011-861/501-5110

Telex: 210491 AMRO CN 
Bank of Tokyo Ltd.

Representative Office

Room No.1701-02

China World Tower

China World Trade Center

No.1, Jian Guo Men Wai Avenue

Beijing 100004

Tel: 011-861/505-2288

Banque Indosuez

Representative Office

Citic Building 12/F Office No.5

19 , Jianguomenwai Dajie

Tel: 011-861/500-3574

Fax: 011-861/500-4930

Telex: 22909 BISPK CN

Citibank, N.A.

Representative Office

18th floor, Room 1

19 Jinguomenwai Dajie

Beijing 10004

Tel: 011-861/500-4425

Fax:011-861/512-7930

Telex: 22816 CTBBJ CN

Dresdner Bank AG

Representative Office

Office C 402, Beijing Lufthansa Center

50, Liangmaqiao Road

Chaoyan District

Beijing 100016

Tel: 011-861/463-1302

Fax:011-861/463-1003

Telex: 210712 dreba cn

Hongkong and Shanghai Banking Corporation

Representative Office

Suite 149, Jianguo Hotel

Jianguomenwai Dajie

Tel: $011-861 / 500-1121$ or $500-2233$, Ext. $145,147,485149$

Fax: 011-861/500-10,74

Telex: 22429 HSBCR CN 
J.P. Morgan \& Co. Inc.

60 Wall Street

New York, NY 10260

Tel: $212 / 648-8416$

Fax:212/648-5184

Mitsubishi Bank Limited

Representative Office

Room 1, 19th Floor

International Building

19 Jianguomenwai Dajie

Beijing 100004

Tel: 011-861/500-3345

Fax:011-861/512-7131

Sanwa Bank Limited

Representative Office 6th Floor, Chang Fu Gong

Office Building

A-26 Jianguomenwai Dajie

Beijing 100004

Tel: 011-861/2143-30200

Fax:011-861/2143-36400

Societe Generale

Representative Office

Scite Tower, Room 1504

22 Jianguomenwai Dajie

Beijing 100004

Tel: 011-861/4512-3666

Fax: 011-861/4512-7485

*This list does not represent a complete listing of U.S. and forcign banks active in the Chinese market; it is meant to highlight those leading U.S. and foreign banks most active in project financing and loan syndications.

\section{F. TECHNICAL ASSISTANCE \& TRAINING:}

\section{F.1. U.S. Government Sources}

\section{U.S. Agency for International Development (USAID)}

USAID is not authorized to operate in China 


\section{F.2. Multilateral Sources}

\section{World Bank}

- $\quad$ Energy Efficiency Cross-Support Team

In addition to the China and Mongolia Department and Industry and Energy Division of the World Bank, the Industrial and Energy Department of the Central Vice-Presidency for Finance and Private Sector Development of the World Bank provides cross-support for sectoral and geographic departments of the Bank. Cross-support is provided for project lending, institutional development, and technical assistance related to energy efficiency and conservation and rural, household, and renewable energy initiatives. This cross-support team can provide implementation support for energy efficiency components of on-going Bank project lending and technical assistance as well as assess and monitor state-of-the-art technology and energy management practices for key enduser sectors.

\section{Contact: Karl Jechoutek, Division Chief}

Industry and Energy Department

Vice Presidency for Finance and Private Sector Development

World Bank

Washington, DC 20433

Tel: 202/458-6391

Fax: 202/477-0542

\section{F.3. In Country Sources}

\section{Beijing Energy Efficiency Center (BECon)}

BECon was established to develop sustainable policies and promote business ventures in energy efficiency in the Chinese economy. BECon's activities will focus on providing policy advise to central and local government agencies; supporting energy efficiency business development; creating and coordinating technical training programs; and raising general public awareness of the importance on the need to conserve energy. Battelle, Pacific Northwest Laboratory, World Wildlife Fund, Lawrence Berkeley Laboratory, and ERI founded BECon. Core funding for BECon was provided by the U.S. Department of Energy for the Center's first two years of operation. Now in its second year of operation, BECon plans to become more business-oriented and hopes, by its third year, that it will be a self-sustaining organization serving as a broker for Chinese energy projects. Integrated resources planning, cogeneration, lighting, and motors are priority areas, with an intent to possibly include renewable energy and gas.

$\begin{array}{ll}\text { Contact in Beijing: } & \text { Zhou Dadi, Director } \\ & \text { BECon } \\ \text { Building 917, An Wai Da Tun Lu } \\ \text { 100101 Beijing China } \\ \text { Tel \& Fax: 011-861/973-2059 } \\ \text { Alternate Fax: 011-861/208-3704 } \\ \text { E-mail: zhoudd@bepc2.ihep.ac.cn }\end{array}$


Contact in U.S.: $\quad$ William Chandler, Senior Scientist

Battelle

901 D Street, SW, Suite 900

Washington, DC 20024-2115

Tel: 202/646-5242

Fax: 202/646-5233 


\section{G. INDEX}

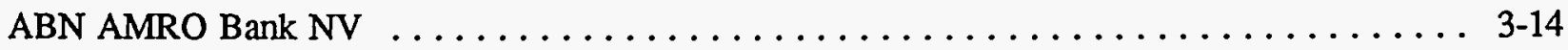

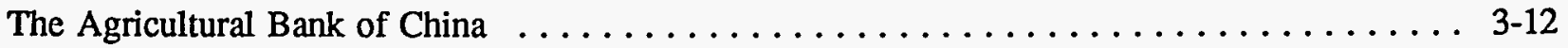

Agricultural Development Bank of China (ADBC) $\ldots \ldots \ldots \ldots \ldots \ldots \ldots \ldots \ldots \ldots$

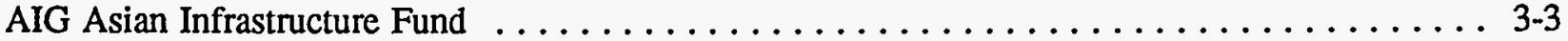

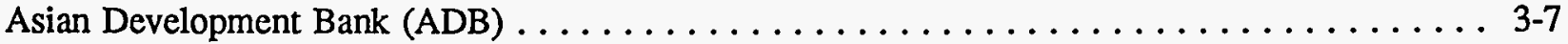

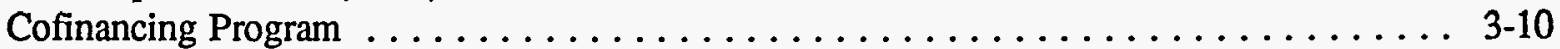

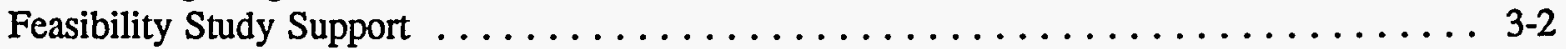

Bank of China . . . . . . . . . . . . . . . . . . . . . . . . . . 3-13

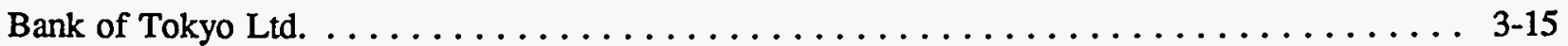

Banque Indosuez . . . . . . . . . . . . . . . . . . . . . . $3-15$

Beijing Energy Efficiency Center (BECon) $\ldots \ldots \ldots \ldots \ldots \ldots \ldots \ldots \ldots \ldots \ldots \ldots \ldots$

China Investment Bank . . . . . . . . . . . . . . . . . . . . . . . 3-13

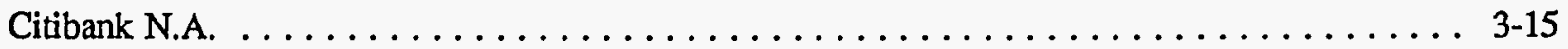

CITIC Industrial Bank . . . . . . . . . . . . . . . . . . . . . 3-13

Committee on Energy Efficiency Commerce and Trade (COEECT) . . . . . . . . . . . . 3-2

Committee on Renewable Energy Commerce and Trade (CORECT) . . . . . . . . . . . . 3-1

Dresdner Bank AG . . . . . . . . . . . . . . . . . . . . . . . . 3-15

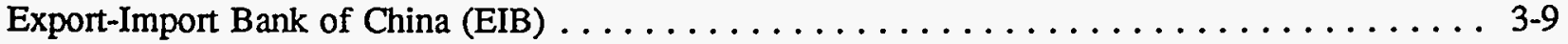

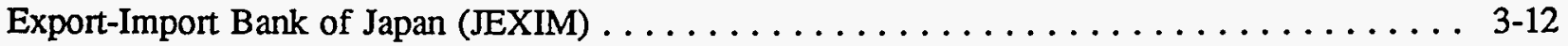

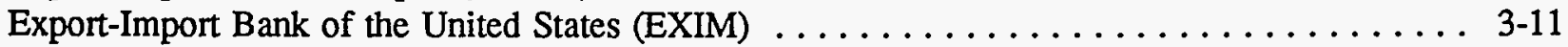

EXIM Engineering Multiplier Program . . . . . . . . . . . . . . . . . . 3-1

EXIM Project Finance Program . . . . . . . . . . . . . . . . . . . 3-3

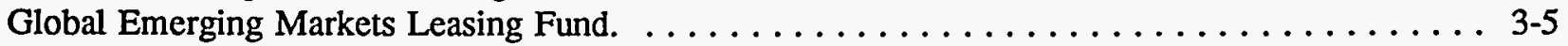

Global Environment Facility $(\mathrm{GEF}) \ldots \ldots \ldots \ldots \ldots \ldots \ldots \ldots \ldots \ldots \ldots \ldots$

Global Power Investments Fund $\ldots \ldots \ldots \ldots \ldots \ldots \ldots \ldots \ldots \ldots \ldots \ldots$

Guangdong Development Bank . . . . . . . . . . . . . . . . . . . . 3-13

Hong Kong and Shanghai Banking Corporation $\ldots \ldots \ldots \ldots \ldots \ldots \ldots \ldots \ldots \ldots \ldots$

Industrial \& Commercial Bank of China . . . . . . . . . . . . . . . . . . . . . 3-14

International Bank for Reconstruction and Development (WORLD BANK) . . . . . . . . 3-7,10

International Finance Corporation (IFC) $\ldots \ldots \ldots \ldots \ldots \ldots \ldots \ldots \ldots \ldots \ldots \ldots \ldots \ldots \ldots$

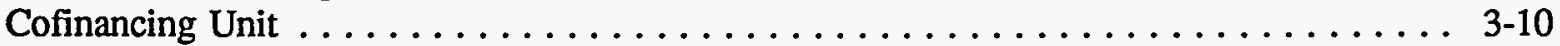

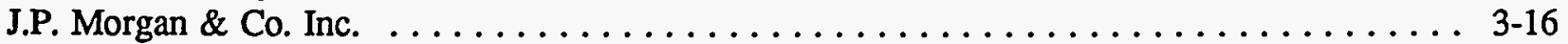

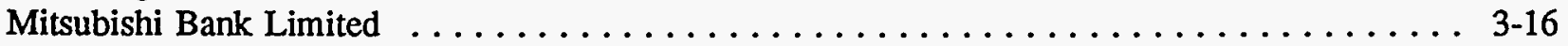

Overseas Private Investment Corporation (OPIC) $\ldots \ldots \ldots \ldots \ldots \ldots \ldots \ldots \ldots \ldots \ldots$

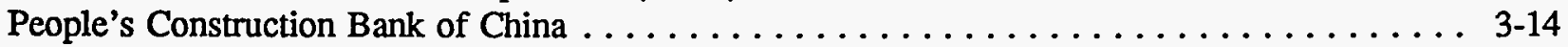

Peregrine Asian Infrastructure Fund $\ldots \ldots \ldots \ldots \ldots \ldots \ldots \ldots \ldots \ldots \ldots \ldots$

Sanwa Bank Limited . . . . . . . . . . . . . . . . . . . . . . . . . . . . 3-16

Shenzhen Development Bank ... . . . . . . . . . . . . . . . . . . . 3-14

Societe Generale . . . . . . . . . . . . . . . . . . . . . . . . . 3-16

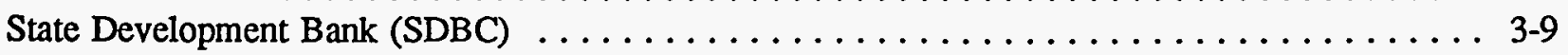

U.S. Agency for International Development (USAID) $\ldots \ldots \ldots \ldots \ldots \ldots \ldots \ldots \ldots \ldots$. . . . . . . . .

U.S. Trade and Development Agency (TDA) $\ldots \ldots \ldots \ldots \ldots \ldots \ldots \ldots \ldots \ldots \ldots$. $\ldots \ldots \ldots$

World Bank . . . . . . . . . . . . . . . . . . . . . . . . . .

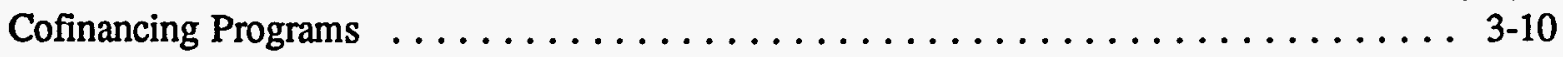

Energy Efficiency Cross-Support Team $\ldots \ldots \ldots \ldots \ldots \ldots \ldots \ldots \ldots \ldots \ldots \ldots \ldots \ldots$ 

4. INDIA 


\section{A. FEASIBILITY FINANCING:}

\section{A.1. U.S. Government Sources}

\section{U.S. Trade and Development Agency (TDA)}

TDA is an independent, U.S. government agency that provides funding for feasibility studies related to major infrastructure projects that offer significant export opportunities for U.S. products and services. Where appropriate, TDA may provide funding for technical seminars, conferences, and orientation visits to the United States. TDA provides funding in the form of non-reimbursable grants for studies to determine the technical, economic, and financial feasibility of major projects and to provide detailed data for making decisions on how to proceed with project implementation. All proposed projects must have the host government's approval, meet the country's development priorities, create significant U.S. export potential, and demonstrate the ability to attract funding for the project implementation phase. TDA's participation usually ranges from $\$ 150,000$ to $\$ 750,000$.

Contact: Dan Stein, Regional Director

Russia, Newly Independent States, South Asia \& Mongolia

U.S. Trade and Development Agency

1621 North Kent Street

Arlington, VA 22209

Tel: $703 / 875-4357$

Fax: 703/875-4009

TDA also has trust fund accounts with multilateral institutions like the World Bank, International Finance Corporation (IFC), and European Bank for Reconstruction and Development (EBRD). This mechanism can be used to support feasibility studies that are tied to specific projects these institutions would likely support. In the case of the IFC, for example, project proposals must demonstrate that they are commercially viable and meet IFC investment threshold criteria as well as the funding requirements of TDA.

At TDA, for general information on trust fund accounts, contact:

Barbara Bradford

Tel: 703/875-4357

Fax: 703/875-4009

To inquire about TDA Trust Funds at the IFC, contact:

Alakadri Bose

Tel: 202/473-0551

Fax: 202/676-1513

The International Fund for Renewable Energy and Energy Efficiency (IFREE)

Funded by the U.S. Agency for International Development, U.S. Department of Energy, the Rockefeller Foundation, and the U.S. Environmental Protection Agency, IFREE facilitates increased access to funding for renewable energy, energy efficiency, and, generally, environmentally-sound projects in developing countries, including India. Under the Prefeasibility Study Program, IFREE offers up to $\$ 50,000$ to support up to 50 percent of prefeasibility study costs, which enables project developers to secure project finance or additional funding for detailed project analyses required by private lenders and U.S. government 


\title{
INDIA
}

agencies for the evaluation of projects. Energy efficiency and renewable energy, i.e., biomass, geothermal, small hydropower, natural gas, solar photovoltaic, solar thermal, or wind energy projects are considered. Projects must be commercially viable, identify sources of funding for the full feasibility study and incountry partners, and use predominantly U.S. equipment, materials, and services.

\author{
Contact: Patrick D'Addario \\ IFREE \\ 777 North Capital Street, NE, Suite 805 \\ Washington, DC 20002 \\ Tel: 202/408-7916
}

Fax: 202/371-5116

Export-Import Bank's (EXIM) Engineering Multiplier Program

EXIM's Engineering Multiplier Program funds project-related feasibility studies and pre-construction design and engineering services. Under this program, EXIM offers fixed-rate loans and guarantees to foreign buyers of these services. This program is designed to generate additional overseas sales of U.S. goods and services since the foreign buyer is more likely to order U.S. equipment and services for a construction project on which U.S. engineers, designers, and architects performed the work. Up to $\$ 10$ million in the value of U.S. exports are covered. Projects supported under this program must generate subsequent U.S. export orders valued at no less than $\$ 10$ million or double the original export contract, whichever is greater. Direct loans are extended for up to 85 percent of the U.S. export value. The foreign buyer must match that with a 15 percent cash payment to the U.S. company. EXIM also offers guarantees for commercial financing for approved project-related local costs in the host country of up to 15 percent of the U.S. contract cost. If the project goes forward with U.S. goods and services, EXIM may extend a loan and/or guarantee, in which case the loan can then be rolled into the later financing.

Contact: James Mahoney, Vice President

Engineering Division

Export-Import Bank of the United States

811 Vermont Avenue, NW, Room 1167

Washington, DC 20571

Tel: $202 / 565-3571$

Fax: 202/565-3584

Environmental Enterprises Development Initiative (EEDI)

EEDI is a program funded by the U.S. Agency for International Development's United States - Asia Environmental Partnership (US-AEP), which offers financial assistance to U.S. companies to conduct preinvestment/feasibility studies of identified environmental investments in eligible countries in Asia, including India. This initiative is part of the efforts of the Overseas Private Investment Corporation (OPIC), an independent U.S. govemment agency, to stimulate increased investment by U.S. environmental firms in Asia's rapidly expanding markets for environmental technology, services, and products. EEDI provides support to eligible U.S. investors for: market assessments, business plans, investor reviews, technology checks, prototype or pilot project implementation, or other pre-investment analyses. The U.S. company is expected to contribute at least 50 percent of the cost of the study (25 percent for small businesses), 50 percent of which must be in cash. OPIC can support up to $\$ 100,000$ per project. Proposed projects must have at least 25 percent U.S. equity and be majority private sector-owned, result in no diversion of U.S. jobs or negative environmental impacts on the host country, and have a positive developmental impact on the host country. The U.S. sponsor will be required to pay a success fee 
equivalent to OPIC's contribution to the pre-investment study should the project proceed based on the results of the OPIC-funded study.

Contact: Bosworth Dewey OPIC

Tel: $202 / 336-8658$

Fax: 202/408-5155

Committee on Renewable Energy Commerce and Trade (CORECT)

CORECT is an interagency working group comprised of representatives from 14 U.S. Federal government agencies, chaired by the U.S. Department of Energy. CORECT works closely with the U.S. Export Council for Renewable Energy (US/ECRE), an industry consortium of seven renewable energy trade associations, to promote renewable energy exports in international markets and ensure that renewable energy technologies and applications are integrated in development projects.

Contact: Ronald Bowes, Director

Office of Technical Assistance

Energy Efficiency and Renewable Energy

U.S. Department of Energy

1000 Independence Avienue, SW, Room 5E-036

Washington, DC 20585

Tel: 202/586-2959 Fax: 202/586-1605

\section{Committee on Energy Efficiency Commerce and Trade (COEECT)}

COEECT is an interagency working group comprised of representatives from 14 U.S. Federal government agencies, chaired by the U.S. Department of Energy. COEECT works closely with the Energy Efficiency Export Council to undertake market assessment for energy efficiency products and services, identify project financing from federal and multilateral institutions, and address the specific needs of the energy efficiency products and services industry.

Contact: Ronald Bowes, Director

Office of Technical Assistance

Energy Efficiency and Renewable Energy

U.S. Department of Energy

1000 Independence Avenue, SW, Room 5E-036

Washington, DC 20585

Tel: 202/586-2959

Fax: 202/586-1605

\section{A.2. Multilateral Sources}

Asian Development Bank

ADB does perform pre-investment and/or feasibility studies usually for projects in which it is interested in investing. Interested parties should track the ADB procurement notice bulletins. To obtain information on $\mathrm{ADB}$ procurement opportunities, contact the representatives below. 
Contact: Janet Thomas, Procurement Liaison

Asian Development Bank

\#6 ADB Avenue

1501 Madaluyuong Metro

Manila Philippines

Tel: 011-632/890-9364

Fax: 011-632/890-9713

-or-

Mary Alice Healy

U.S. Department of Commerce

Room 1107

Washington, DC 20230

Tel: 202/482-4333

Fax: 202/273-0927

\section{A.3. In Country Sources}

No known available sources.

\section{B. PROJECT FINANCE - PRIVATE SECTOR:}

\section{B.1. U.S. Government Sources}

Overseas Private Investment Corporation (OPIC)

This independent, U.S. government agency provides project financing, investment insurance, and a variety of investor services. OPIC has recently supplemented its finance products by supporting privately owned and managed equity investment funds. OPIC is currently supporting equity funds and global environmental enterprises initiatives worldwide, including India.

\section{Project Financing:}

OPIC provides medium to long-term financing (over 3 years), available through loan guarantees and/or direct loans. Loan guarantees cover both commercial and political risks. OPIC has approximately $\$ 1$ billion available to finance projects. OPIC offers direct loans for international investment projects, which range from $\$ 2$ to $\$ 200$ million. However, OPIC typically does not support projects under $\$ 10$ million. OPIC will participate in up to 50 percent of the total project cost for a new venture and up to 75 percent of the total cost of an expansion.

Contact: Richard Greenberg, Regional Manager

Overseas Private Investment Corporation

1100 New York Avenue, NW

Washington, DC 20527

Tel: 202/336-8652

Fax: 202/408-5155 
Export-Import Bank's Project Finance Program

EXIM Bank recently launched a new program to finance projects that are dependent solely on the project cash flow of the particular project for repayment. Projects under this program can not rely on sovereign guarantees to assure repayment as is normally required under typical EXIM Bank export credit packages. Under this program, EXIM offers (1) allowance of up to 15 percent foreign content in the US package; (2) financing of interest accrued during construction related to the EXIM Bank financing facilities; (3) financing of host country local costs of up to 15 percent of the US contract value; (4) maximum repayment term allowed under the OECD guidelines; (5) no minimum/maximum limitations on project size; (6) flexible coverage and equity arrangements; (7) exposure fee commensurate with risk; and (8) rapid application processing.

Contact: Diane Rudo, Vice President

Project Finance Division

Export-Import Bank of the United States

811 Vermont Avenue, NW

Washington, DC 20571

Tel: $202 / 565-3690$

Fax: 202/565-3695

Environmental Enterprises Assistance Fund (EEAF)

EEAF invests in projects and companies in developing countries, including India. The main objective of EEAF is to catalyze the spread of renewable energy, energy efficiency, and other environmentally responsible technologies. EEAF provides direct loans and equity placements in environmentally-sound, commercially viable projects and capitalizes local investment funds. EEAF provides financial support for projects under $\$ 2$ million in renewable energy systems, energy efficient technologies, and environmentally responsible management of organic waste. Direct loans are made at concessional rates, but equity investments are expected to provide higher returns than conventional financing arrangements. On a limited, cost-reimbursable basis, EEAF may provide technical assistance for training and technical analysis of proposed projects.

Contact: Brooks Browne, President

Environmental Enterprises Assistance Fund

1901 North Moore Street

Suite 1004

Arlington, VA 22209

Tel: 703/522-5928

Fax: 703/522-6450

The investment funds listed below have been capitalized primarily with funds from U.S. government and multilateral organizations:

AIG Asian Infrastructure Fund

The AIG Asian Infrastructure Fund makes equity and convertible debt investments in private infrastructure and related projects in priority sectors in countries in the Asia Pacific region, including India. The Fund is capitalized at US $\$ 1,086$ million. The core investors are the American International Group (AIG), the Singapore Government Investment Companies, US pension funds, and the Brunei government. 35 percent to 50 percent of the Fund is expected to be invested in China. The balance of the Fund will be dedicated to investments in Indonesia, Malaysia, the Philippines, Taiwan, Thailand, and other Asian countries, 
including India. The Fund is prepared to invest in greenfield, expansion, privatizations, pre-IPO projects, and participate in cofinancing opportunities. Typical investments range from US\$10 to US\$100 million for primary projects and US $\$ 2$ million to US $\$ 20$ million for secondary projects. The Fund may invest up to US\$100 million in any single project but will participate as a minority stockholder. Targeted sectors are power and related energy, telecommunications, transportation, natural resource development, petrochemical, environment, and infrastructure related facilities.

Contact in U.S.: $\quad$ AIG-Asian Infrastructure Fund

$$
\begin{aligned}
& \text { c/o Emerging Markets Corporation } \\
& \text { Scott Glecken, Director - Marketing } \\
& 1828 \text { L Street, N.W., Suite } 900 \\
& \text { Washington, D.C. } 20036 \\
& \text { Tel: 202/331-9051 Fax: 202/331-9250 }
\end{aligned}
$$

Peregrine Asian Infrastructure Fund

The Peregrine Fund will be capitalized at approximately US $\$ 1$ billion and is expected to close sometime between May and mid-July, 1995. The International Finance Corporation, Asian Development Bank, and the Asian Infrastructure Development Fund Ltd. are the initial investors of the Fund and Peregrine Investments and Frank Russell Investments are its sponsors. The main objective of the Fund is to achieve long-term capital appreciation through infrastructure investments in Asia, including India. The Fund will invest in non-listed equity or equity linked securities of entities that are engaged in the development, ownership, or operation of infrastructure facilities. Target sectors are primarily power, transportation, and telecommunications.

\section{Contact: Edward Landry}

Asian Infrastructure Fund Management Company Ltd.

16-18 Queen's Road Central

New World Tower

Hong Kong

Tel: $011-852 / 2825-1169$

Fax: 011-852/2845-0786

-or-

Peregrine Brokerage Inc.

780 Third Avenue, Suite 2601

New York, NY 10017

Tel: $212 / 593-5920$

Fax: 212/593-5932

\section{Global Power Investments Fund}

GE Capital Corporation and Soros Fund Management established Global Power Investments Fund, a new venture capital fund, which will make subordinated debt and equity investments in privately-owned electric power generating facilities in emerging markets, including India. The Fund is capitalized at $\$ 500$ million with initial capital contributions by GE Capital, Soros Fund Management, Quantum Industrial Holdings, and the International Finance Corporation (IFC). Additional capital will be raised to reach a total capitalization target of at least $\$ 2.5$ billion. The Fund will primarily invest in the new construction of power plants (gas-fired, coal-fired, and possibly cogeneration), although it may invest in existing facilities. Global 
Power Investments will look to projects that use commercially-viable, proven technologies. GE Capital will take the lead on identifying projects in the field, providing the analysis of risks and returns, negotiating the terms of transaction, and managing the portfolio of investments. Soros Fund and the IFC will provide investment advisory services and assist in making investment decisions on behalf of the Fund.

Contact: Dick Fowler

GE Capital Corporation

1600 Summer Street, 6th Floor

Stamford, CT 06927

Tel: 203/357-4385 Fax: 203/357-6289

-or-

Everett Smith

Singapore Office (handles investments in India)

Tel: 011-65-326-3179

Fax: 011-65-326-3152

Global Environmental Emerging Markets Fund, L.P.

This fund is designed to take significant minority equity or equity-related positions in private companies in emerging markets in Africa, Asia, Latin America, and Eastern Europe. The Fund has raised $\$ 70$ million in capital through an offering of its securities to sophisticated investors, including financial institutions, in the U.S. and Europe. These securities will be partnership equity interests and OPIC-guaranteed longterm partnership notes, offered together or separately. The Fund will invest up to $\$ 10$ million in alternative energy, water treatment, air pollution control and waste management. Currently, the Fund is looking at a number of opportunities in the area of energy conservation and demand side management. The Global Environment Fund, L.P. manages this new fund and serves as its general partner. Projects are currently being sought for review and consideration.

\section{Contact: H. Jeffrey Leonard, President}

Global Environmental Fund, L.P.

1201 New York Avenue, NW

Suite 220

Washington, DC 20005

Tel: $202 / 789-4500$

Fax: 202/789-4808

\section{B.2. Multilateral Sources}

Intemational Finance Corporation (IFC)

IFC, a member of the World Bank, is the largest source of direct financing for private sector projects in developing countries; including India. Unlike the World Bank, IFC lends directly to private companies and does not request guarantees from host-country governments. It can provide loans, make equity investments in private businesses, and mobilize additional loan and equity financing in international financial markets through syndication efforts. Although IFC invests and lends on market terms, it finances projects unable to obtain sufficient funding on reasonable terms from other sources. Increasingly, the IFC is working through intermediary financial facilities in order to support smaller scale projects and supporting cofinance arrangements with the World Bank (GEF) and EBRD. 
Loans and equity investments are usually limited to no more than 25 percent of project cost. IFC's minimum investment project support is $\$ 10$ million. Funds may be used for foreign or local expenditures related to overall project costs, i.e, fixed assets, permanent working capital, interest during construction, and pre-operating cost. IFC can invest up to 35 percent of the share capital as long as it is not the major shareholder. It turns over its equity often by sale to local investors when the investment has matured. Both fixed and variable rate loans are offered; rates are detcrmined on a commercial basis. Terms normally run from seven to twelve years.

Contact for India:

Contact for Power Projects:

Contact for Environment:

\author{
Denise Leonard, Manager \& Chief of Mission \\ Asia Department, Division III \\ International Finance Corporation \\ No. 25 Maker Chambers VI \\ Nariman Point \\ Bombay, India \\ Tel: 011-91-22/285-5262 or 5263 \\ Fax:011-91-22/285-5272 \\ -or- \\ Christopher Goss \\ International Finance Corporation \\ 1850 Eye Street, NW, Room 11-063 \\ Washington, DC 20433 \\ Tel: $202 / 473-8386$ \\ Fax: 202/334-0212
}

Mr. Vijay Chaudhry, Manager

Power Division

Tel: 202/473-0575

Fax: 202/676-1719

Martyn Riddle, Manager

Environmental Unit

Tel: 202/473-0661

Fax: 202/676-9495

\section{B.3. In Country Sources}

No known available sources.

\section{PROJECT FINANCE - PUBLIC SECTOR:}

\section{C.1. U.S. Government Sources}

No known available sources. 


\section{C.2. Multilateral Sources}

Asian Development Bank (ADB)

Headquartered in Manila, the Philippines, the Asian Development Bank is a development finance institution whose mandate is to promote the economic and social progress of its 53 development member countries in the Asian and Pacific region. On behalf of its member countries, the Bank aims to (1) make loans and equity investments to enhance their economic and social development; (2) promote investment of public and private capital to meet their developmental goals; (3) provide technical assistance for the preparation and execution of their development projects and programs, and advisory services; and (4) respond to requests for assistance in coordinating their development policics and plans.

Contact for India:

Contact for Energy:
Mr. Y. Iwasaki, Programs Manager

Division II

Programs Department West

Tel: 011-632/632-6223

Fax: 011-632/636-2225

Mr. Ed Hourihan, Senior Financial Analyst

Infrastructure, Energy, and Financial Sectors Department

(IWD) Energy Division West

Tel: 011-632/632-6434

Fax:011-632/636-2335

International Bank for Reconstruction and Development (WORLD BANK)

The World Bank, a multilateral lending agency, is the largest source of financial and technical assistance to the public sector in developing countries. The Bank also makes policy-oriented structural and sectoral adjustment loans to support market-oriented institutional reforms. The Bank lends to member governments for public sector, development projects, not to the private sector. The Bank affiliate that lends to the private sector is the IFC. Loans are made only to governments or to agencies that can obtain a government guarantee for repayment. Bank funds are used by member governments to import food and equipment, fund project construction, and obtain consultant services. Interest rates on Bank loans are set a half a percentage point above the Bank's average cost of borrowing and repayment terms are normally twelve to fifteen years, including a three to five year grace period.

\section{Contact for India:}

Heinz Vergin, Director

South Asia Regional Office

Country Department II, India

World Bank

1818 H Street, NW

Room G-3025

Washington, DC

Tel: $202 / 458-0332$

Fax: 202/477-4510 
Contact for Energy:

Resident Representative:
Jean-Francois Bauer

Energy Operations

South Asia Regional Office

Tel: 202/458-1470

Fax: 202/477-8556

Mr. Javad Khalilzadeh-Shirazi

World Bank Resident Mission

P.O. Box 416

New Delhi 110001, India

-or-

70 Lodi Estate

New Delhi 110003, India

Tel: 011-91-11/461-7241, 42, 43, 44

Fax:011-91-11/461-9393

Global Environment Facility (GEF)

Established in 1990, GEF provides grants for investment projects and tcchnical assistance to assist developing countries to address four main global (transboundary) environmental problems: global warming, pollution of international waters, destruction of biological diversity, and depletion of the ozone layer. GEF is co-managed by the World Bank, U.N. Development Programme, and the U.N. Environmental Programme. To qualify for funding under the GEF, projects must be innovative, demonstrate the effectiveness of a particular technology or approach, and fall into one of the four priority areas. GEF funding is possible if the project offers substantial global benefits, but is unlikely to be viable without some concessional funding or if a project is economically viable but requires supplemental finance to bring about global benefits.

GEF projects can either be free-standing, components of World Bank projects, or pass through the IFC to support private sector ventures that have both important demonstration benefits and host government endorsement. Free-standing GEF projects are limited to $\$ 10$ million, and GEF components of World Bank projects must not exceed $\$ 30$ million. GEF funds can leverage regular Bank projects by paying the additional cost of incorporating environmentally benign technologies in Bank-supported projects. GEF funds would cover the difference in cost between what the host country is willing to pay and the cost of the benign technology. Use of GEF funds through the IFC can be used if the sponsor/lender could not otherwise underwrite the risk under prevailing market conditions; funds cannot be used to avert normal commercial risks.

Contact: Mr. Robin Broadfield, Regional Coordinator for Africa \& South Asia

. Global Environment Coordination Division

The World Bank

1818 H Street, NW Room S-2131

Washington, DC 20433

Tel: 202/473-4355 Fax: 202/522-3256 


\section{C.3. In Country Sources}

No known available sources.

\section{COFINANCING:}

\section{D.1. U.S. Government Sources}

Not applicable.

\section{D.2. Multilateral Sources}

International Bank for Reconstruction and Development (World Bank)

Although the Bank mainly lends to governments and government agencies, it can also provide guarantees to commercial lenders for public and private sector projects. The Bank's guarantee program currently covers loans totalling $\$ 1$ billion. As a way to attract private sector capital and encourage direct foreign investments in developing countries, the Bank's Executive Directors approved a proposal making guarantees a mainstream instrument of Bank operations in September 1994. There are two types of guarantees offered: (1) partial risk guarantee that covers non-performance of sovereign contractual obligations or other contractual non-performance problems in a project and (2) partial credit guarantee which extends maturities beyond what private lenders could otherwise provide.

By covering risks that the market would not bear, the Bank's guarantee program helps reduce the cost of financing projects by guaranteeing against contractual non-performance, offers flexibility to structure project financing by extending maturities, and attracts private sources of capital by sharing risks of undertaking infrastructure projects in developing countries.

Contact: Nina Shapiro, Manager

Project Finance Group

CoFinancing and Financial Advisory Department

World Bank

Tel: 202/473-1650

Fax: 202/477-0218

\section{Asian Development Bank (ADB)}

The ADB syndicates participation in loans and provides parallel and joint financing as a way to enable commercial banks to take on the risks of lending to developing countries and its clients access additional financing sources from international capital markets, and to raise long-term finance on reasonable terms on behalf of its clients.

Contact: Eikki Jappinen, Manager

Cofinance Unit

Asian Development Bank

Tel: 011-632/632-6314

Fax:011-632/636-2456 
International Finance Corporation (IFC)

The IFC syndicates participation in loans and provides parallel and joint financing as a way to enable commercial banks to take on the risks of lending to developing countries and its clients access additional financing sources from international capital markets, and to raise long-term finance on reasonable terms on behalf of its clients.

Contact: Richard Parry

Syndications Department

IFC

Tel: 202/473-0398

Fax:202/334-8713

\section{D.3. In Country Sources}

Not applicable.

\section{E. TRADE FINANCE:}

\section{E.1. U.S. Government Sources}

\section{Export-Import Bank of the United States (EXIM)}

EXIM is an independent, U.S. government agency that provides support for U.S. exports through shortand medium-term export credit insurance, medium- and long-tcrm loan guarantees, medium- and long-term direct and intermediary loans, working capital guarantees, and limited recourse project financing. EXIM will consider alternative energy projects in energy efficiency and renewable energy that incorporate geothermal, solar, wind, hydroelectric, cogeneration and biomass technologies.

EXIM will only help finance exports of U.S. goods and services containing at least 50 percent U.S. content. The entire value of the shipment is covered under short-term export credit programs, while 100 percent of the U.S. content of the shipment is covered under medium- and long-term programs provided that EXIM's support does not excecd 85 percent of the export price. EXIM's short-term programs cover up to 360 days, medium-term programs cover up to five ycars, and long-term programs cover twelve years.

EXIM financing may not be used to support the sales of defense articles and services to any country for offensive or defensive military purposes, except for anti-narcotics purposes under limited circumstances.

EXIM's short-term, medium-term, and long-term programs are all available to support U.S. exports to India. For public sector transactions, EXIM usually requires a guarantec from the Government of India (i.e., sovereign guarantee) or a commercial bank with which EXIM considers an acceptable guarantor. For private sector transactions, EXIM requires that a commercial bank acceptable to EXIM act as obligor or guarantor. However, EXIM has made exceptions to this requirement and has accepted to take on unsecured risk for transactions involving very strong borrowers.

Export of capital equipment may be supported by EXIM's long-tcrm loans and guarantees (up to ten years), or medium-term loans, guarantees, and insurance (five ycars and up to seven years under certain 
circumstances). Exports of consumer goods, spare parts, and raw materials may be supported under EXIM's short-term credit insurance program (up to 180 days).

EXIM has established a number of Credit Guarantee Facilitics with three principal Indian Development Banks - Industrial Development Bank of India (IDBI), Industrial Financial Corporation of India (IFCI), and Industrial Credit and Investment Corporation of India (ICICI), and the Export-Import Bank of India. This Credit Guarantee Facility is a medium-term line of credit extended by a U.S. bank to these Indian banks, which is in turn guaranteed by EXIM. Bank of New York, Chemical Bank, and Citibank International are the three participating U.S. banks. Indian companies may approach one of the three participating Indian banks to obtain a loan to purchase U.S. goods. The Indian bank would finance the transaction under the credit facility it has with a participating U.S. bank and would act as obligor.

Contact:

Frank Wilson, Senior Business Development Officer

Business Development Officc

Export-Import Bank of the United States

Tel: 202/565-3900

Fax: 202/565-3931

Contact for India:

Rita R. Murrcll

Loans \& Guarantces

Tel: 202/565-3712

Fax: 202/565-3717

Contact for Environment:

Craig O'Connor

Environmental Liaison Officer

Tel: 202/565-3939

Fax: 202/565-3932

\section{E.2. Multilateral Sources}

Trade finance is primarily through cofinancing export credit facilitics available through multilateral institutions.

\section{Other Sources may include:}

\section{The Export-Import Bank of Japan (JEXIM)}

The Export-Import Bank of Japan (JEXIM) is an independent governmental financial institution of Japan. The mandate of JEXIM is to provide a wide range of financial services to supplement and encourage financing by commercial banks and other financial institutions and to foster Japanese overseas investment and international financial cooperation for economic development worldwide. JEXIM is very aggressive in cofinancing deals with international development and commercial banks and has been quite active in the Indian market. Of particular interest to U.S. companies are untied loans available under JEXIM's "Funds for Development" initiative. This $\$ 120$ billion initiative was launched in June, 1993 to promote economic progress in developing countries through funding for Japanese exporters or project sponsors to finance projects in developing countries. However, financing is also provided to U.S. and other foreign exporters on an "untied" basis, i.e., without a direct link to a Japanese exporter, importer, or project sponsor. 


\section{Contact in U.S.:}

Export-Import Bank of Japan (JEXIM)

2000 Pennsylvania Avenue, NW

Washington, DC

Tel: 202/331-8547

Fax: 202/775-1990

Export-Import Bank of Japan (JEXIM)

8th Floor, Meridien Commercial Tower

8 Windsor Place

New Delhi 110001 India

Tel: $011-91-11 / 371-0430$ or $371-4165$

Fax:011-91-11/371-4895

\section{E.3. In Country Sources}

\section{Export-Import Bank of India}

The International Finance Corporation is providing the Export-Import Bank of India (EXim Bank) with $\$ 25$ million to establish a line of credit to enable EXim Bank of India to provide foreign currency loans to small- and medium-sized export-oriented industrial enterprises in the private sector. This on-lending facility will be used to finance imported and domestic capital goods and technical know-how and services for enhancing the international competitiveness of India's private sector. EXim Bank of India is India's official export credit agency engaged in financing, facilitating, and promoting the foreign trade of India. No contact information for this on-lending facility is currently available. However, for general information on the EXim Bank of India, contact:

Shankarnarayan R. Rao

Resident Representative

Export-Import Bank of India

1735 Eye Street, NW, Suite 517

Washington, DC 20006

Tel: 202/223-3238

Fax: 202/785-8487

-or-

K.C. Barshney, Executive Director

Export-Import Bank of India

Bombay

Tel: 011-91-22/218-0411 
Below is a list of leading State Indian banks:

State Bank of India

International Division, 13th Floor

Madame Cama Road

P.O. Box 10121

Bombay 400021 India

Tel: 011-91-22/202-2426

Fax: 011-91-22/204-0073 or 285-1391

Birendra Kumar

Resident Representative

2001 Pennsylvania Avenue, NW, Suite 625

Washington, DC 20006

Tel: 202/223-5579

Fax: 202/785-3739

Industrial Credit \& Investment Corporation (ICICI)

Mr. Ambikapratap Shingh

Assistant General Manager

173 Backbay Reclamation

Road No. 3

Bombay 400 020-28 India

Tel: 011-91-22/202-2535

Fax: 011-91-22/204-6582

Industrial Development Bank of India

Mr. Omprakash V. Bundellu

Deputy General Manager

IDBI Tower, 22nd Floor

Cuffe Parade

Bombay 400005 India

Tel: 011-91-22/218-1691

Fax: 011-91-22/218-8137

Industrial Finance Corporation of India

Mr. Shrawan Nigam

General Manager

Bank of Baroda Bldg., 8th Floor

16 Sansad Marg

New Delhi 110001 India

Tel: 011-91-11/332-8531

Fax: 011-91-11/332-0425 
Below is a list of U.S. and foreign investment and commercial banks that are active in the Indian market:*
ANZ Grindlays Bank
Mr. Vijay Sharma
Bombay Office
Tel: 011-91-22/271-267
Bank of New York
Mr. Norman Buchbinder
Assistant Treasurer
One Wall Street
New York, NY 10286

Tel: 212/635-7342 Fax: 212/635-7830

Mr. Vikas Jambotkar

Deputy Representative

Bombay Office

Tel: 011-91-22/204-4941 Fax: 011-91-22/204-4942

Chemical Bank

Ms. Rukmini Roy

Vice President

270 Park Avenue

New York, NY 10017

Tel: 212/270-2166 Fax: 2112/270-4004

R. Murlidhar Rao

Vice President

Bombay Office

Tel: $011-91-22 / 243-537$ or $243-491$

Fax: 011-91-22/204-3613

\section{Citibank International}

Mr. Paul Touloumbadjian

Vice President

336 Strand

London England WC2R $1 \mathrm{HB}$

Tel: 011-44-71/438-1870 Fax: 011-44-71/497-8936

*This list does not represent a complete listing of U.S. and forcign banks active in the Indian market; it is meant to highlight those leading U.S. and foreign banks most active in project financing and loan syndications. 


\section{F. TECHNICAL ASSISTANCE \& TRAINING:}

\section{F.1. U.S. Government Sources}

\section{U.S. Agency for International Development (USAID)}

\section{- U.S. Asia Environmental Partnership (US-AEP)}

US-AEP is a coalition of U.S. and Asian businesses, governments, and community organizations working together to promote U.S.- Asian trade and investment linkages. The Partnership provides a number of programs to support US-Asian environmental collaboration and business initiatives: Environmental Fellowship and Training Program, Technology Cooperation Program, Environmental Infrastructure Program, and Regional Biodiversity Conscrvation Network. For India, in addition to these programs, US-AEP provides support for pollution prevention initiatives, clean coal activities, business exchanges, and access to technology data bases.

\section{Contact: US-AEP}

1133 20th Street, NW, Suite 300

Washington, DC 20036

Tel: 202/835-0333

Fax: 202/835-0366

- Energy Management Consultation and Training Project (EMCAT)

EMCAT is a $\$ 22$ million, six year project to improve the efficiency of the Indian electric power sector through energy supply and energy efficiency programs. On the supply side, technical assistance and training is being provided to Indian policy makers to help them efficiently manage and maintain existing generation, transmission, and distribution facilities. The project's focus on energy efficiency side is on energy auditing, cogeneration, and utility demand-side management.

Cuntact: Charlie Fafard

Resource Management Associates of Madison Inc.

202 State Street, Suite 303

Madison, WI 53703

Tel: $608 / 283-2880$

Fax: 608/283-2881

- Program for the Acceleration of Commercial Energy Research (PACER)

This five year (1987-1996), \$20 million program promotes the development of new, innovative products or technologies, which focuses particularly on renewable energy, coal conversion, and energy efficiency. PACER provides grants of up to 75 percent of the project cost (maximum of $\$ 3$ million), or grants of up to 80 percent of research cost (maximum of $\$ 400,000$ ) for research into PACER's areas. 
Contact: Dr. G. Staats, Program Manager

USAID Projects

Pittsburgh Energy Technology Center

P.O. Box 109040

Pittsburgh, PA 15236-0940

Tel: $412 / 802-4802$

Fax: $412 / 802-4818$

- India Private Power Initiative (IPPI)

IPPI is a $\$ 3$ million program to establish a sustainable, environmentally-sound private power industry in India. The program supports technical assistance to build in-country capabilities to evaluate and process pending project proposals resulting from the recent Government of India decision to encourage private investment in the power sector. Assistance is also provided to U.S. developers to find local joint venture partners.

Contact: USAID's Office of Energy and Infrastructure

Private Sector Energy Development Program

1601 North Kent Street, Suite 1102

Arlington, VA 22209

Tel: 202/835-0333

Fax:202/835-0366

- Greenhouse Gas Pollution Prevention Project (GEEP)

GEEP is a seven year (1995-2002), $\$ 19$ million project to demonstrate power generation strategies that reduce greenhouse gas emissions, e.g., carbon dioxide and methane. $\$ 12$ million are earmarked to fund investments in demonstration projects and $\$ 7$ million for technical assistance and training. This project has two components: (1) to promote new technologies and the use of alternative biomass fuels at sugar mill cogeneration facilities; and (2) to set up a research and development center with India's leading power generation utility to study clean coal technologies. Funding for demonstration projects are available under both components.

Contact: USAID's Office of Energy and Infrastructure

Private Sector Energy Development Program

1601 North Kent Street, Suite 1102

Arlington, VA 22209

Tel: 202/835-0333

Fax:202/835-0366

- Trade in Environmental Services and Technologies (TEST)

This five year (1992-97), \$25 million project promotes environmental exports and Indo-U.S. joint ventures. Conditional grants are provided to support the purchase of U.S. and Indian environmental services, technologies, and equipment; establishment of facilities in India with U.S. participation; manufacture of equipment; and technical assistance to Indian environmental services. TEST will also support reverse trade missions to the U.S., and provide information on and review and selection of appropriate technologies. 
Contact: Ed Sanders

Sanders International

1616 P Street, NW, Suite 416

Washington, DC 20036

Tel: 202/939-3480

Fax:202/939-3487

\section{F.2. Multilateral Sources}

\section{World Bank}

\section{- Energy Efficiency Cross-Support Team}

In addition to the South Asia Regional Department of the World Bank, the Industrial and Energy Department of the Central Vice-Presidency for Finance and Private Sector Development of the World Bank provides cross-support for sectoral and geographic departments of the Bank. Cross-support is provided for project lending, institutional development, and technical assistance related to energy efficiency and conservation, and rural, household, and renewable energy initiatives. This crosssupport team can provide implementation support for energy efficiency components of on-going Bank project lending and technical assistance as well as assess and monitor state-of-the-art technology and energy management practices for key end-user sectors.

Contact: Karl Jechoutek, Division Chief

Industry and Energy Department

Vice Presidency for Finance and Private Sector Development

World Bank

Washington, DC 20433

Tel: 202/458-6391

Fax: 202/477-0542

\section{F.3. In Country Sources}

No known available sources. 


\section{G. INDEX}

AIG Asian Infrastructure Fund $\ldots \ldots \ldots \ldots \ldots \ldots \ldots \ldots \ldots \ldots \ldots \ldots \ldots \ldots \ldots \ldots$

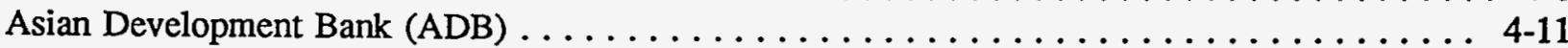

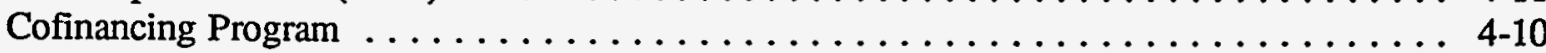

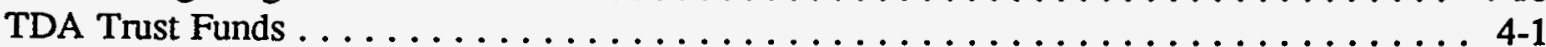

Feasibility Study Support $\ldots \ldots \ldots \ldots \ldots \ldots \ldots \ldots \ldots \ldots \ldots \ldots \ldots \ldots \ldots$

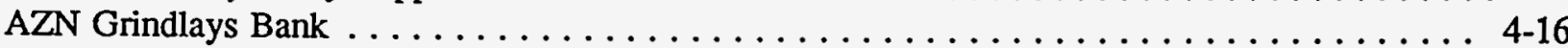

Bank of New York. . . . . . . . . . . . . . . . . . . . . . . . . . $4-16$

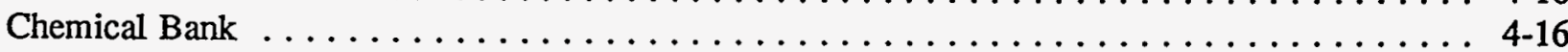

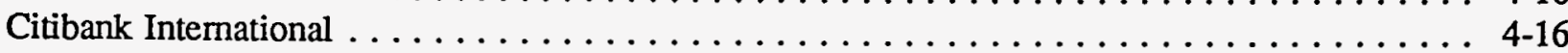

Committee on Energy Efficiency Commerce and Trade (COEECT) $\ldots \ldots \ldots \ldots \ldots \ldots \ldots \ldots . . .44$

Committee on Renewable Energy Commerce and Trade (CORECT) . . . . . . . . . . . . . . 4-3

Energy Management Consultation and Training Project (EMCAT) $\ldots \ldots \ldots \ldots \ldots \ldots \ldots \ldots$. . . . .

Environmental Enterprises Assistance Fund $\ldots \ldots \ldots \ldots \ldots \ldots \ldots \ldots \ldots \ldots \ldots \ldots \ldots \ldots 4-5$

Environmental Enterprises Development Initiative $\ldots \ldots \ldots \ldots \ldots \ldots \ldots \ldots \ldots \ldots \ldots \ldots \ldots$. $\ldots \ldots \ldots$

Export-Import Bank of India . . . . . . . . . . . . . . . . . . . . . . 4-14

Export-Import Bank of Japan (JEXIM) . . . . . . . . . . . . . . . . . . 4 4-13

Export-Import Bank of the United States (EXIM) $\ldots \ldots \ldots \ldots \ldots \ldots \ldots \ldots \ldots \ldots \ldots \ldots \ldots 4-12$

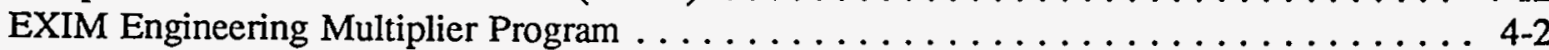

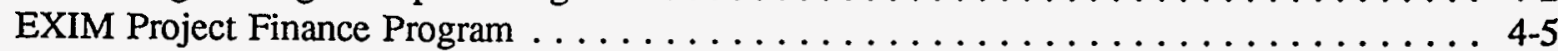

Global Environment Facility (GEF) . . . . . . . . . . . . . . . . . . . . 4-10

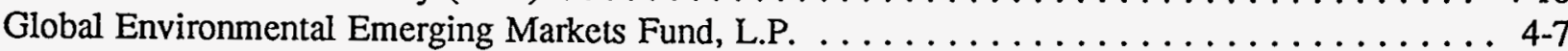

Global Power Investments Fund $\ldots \ldots \ldots \ldots \ldots \ldots \ldots \ldots \ldots \ldots \ldots \ldots \ldots \ldots \ldots \ldots \ldots . \ldots \ldots$

Greenhouse Gas Pollution Prevention Project (GEEP) $\ldots \ldots \ldots \ldots \ldots \ldots \ldots \ldots \ldots \ldots \ldots . \ldots 4-18$

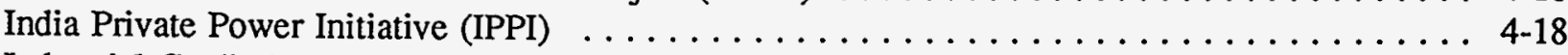

Industrial Credit \& Investment Corporation (ICICI) $\ldots \ldots \ldots \ldots \ldots \ldots \ldots \ldots \ldots \ldots \ldots$. $\ldots \ldots$

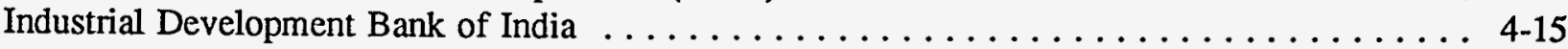

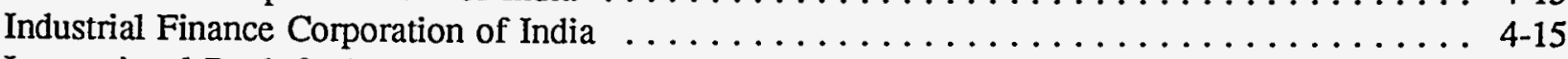

International Bank for Reconstruction and Development (WORLD BANK) . . . . . . . 4 4-9,11,19

International Finance Corporation (IFC) $\ldots \ldots \ldots \ldots \ldots \ldots \ldots \ldots \ldots \ldots \ldots \ldots \ldots \ldots$

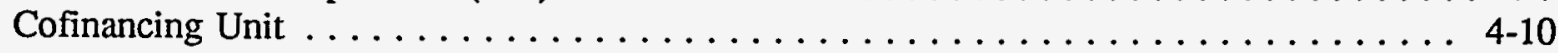

Trust Funds . . . . . . . . . . . . . . . . . . . . . . . . . 4-1

Intemational Fund for Renewable Energy and Energy Efficiency (IFREE) $\ldots \ldots \ldots \ldots \ldots \ldots$. . . .

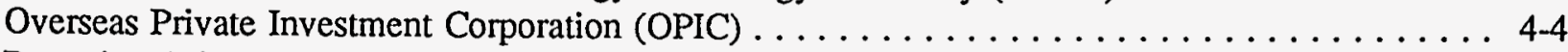

Peregrine Asian Infrastructure Fund $\ldots \ldots \ldots \ldots \ldots \ldots \ldots \ldots \ldots \ldots \ldots \ldots \ldots \ldots$

Program for the Acceleration of Commercial Energy Research . . . . . . . . . . . . . . 4-17

State Bank of India . . . . . . . . . . . . . . . . . . . . . . . . . . 4-15

Trade in Environmental Services and Technologics (TEST) $\ldots \ldots \ldots \ldots \ldots \ldots \ldots \ldots \ldots$. . . . . .

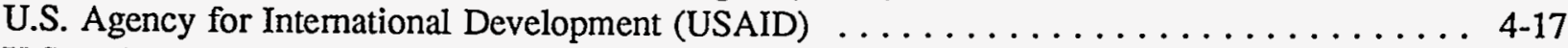

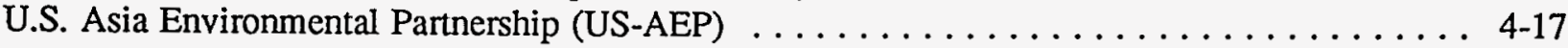

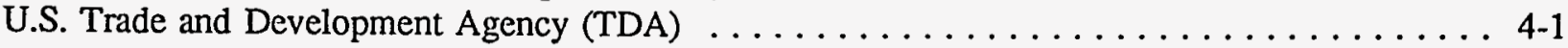

World Bank . . . . . . . . . . . . . . . . . . . . . . . . . . . . . . 4 4-9

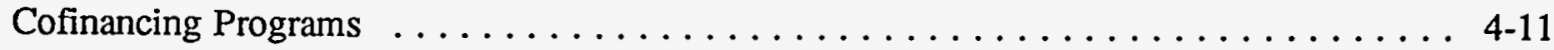

Energy Efficiency Cross-Support Team $\ldots \ldots \ldots \ldots \ldots \ldots \ldots \ldots \ldots \ldots$ 4 .19 
5. PAKISTAN 
. 


\section{A. FEASIBILITY FINANCING:}

\section{A.1. U.S. Government Sources}

\section{U.S. Trade and Development Agency (TDA)}

TDA is not authorized to operate in Pakistan.

Export-Import Bank's (EXIM) Engineering Multiplier Program

EXIM's Engineering Multiplier Program funds project-related feasibility studies and pre-construction design and engineering services. Under this program, EXIM offers fixed-rate loans and guarantees to foreign buyers of these services. This program is designed to generate additional overseas sales of U.S. goods and services since the foreign buyer is more likely to order U.S. equipment and services for a construction project on which U.S. engineers, designers, and architects performed the work. Up to $\$ 10$ million in the value of U.S. exports are covered. Projects supported under this program must generate subsequent U.S. export orders valued at no less than $\$ 10$ million or double the original export contract, whichever is greater. Direct loans are extended for up to 85 percent of the U.S. export value. The foreign buyer must match that with a 15 percent cash payment to the U.S. company. EXIM also offers guarantees for commercial financing for approved project-related local costs in the host country of up to 15 percent of the U.S. contract cost. If the project goes forward with U.S. goods and services, EXIM may extend a loan and/or guarantee, in which case the loan can then be rolled into the later financing.

Contact: James Mahoney, Vice President

Engineering Division

Export-Import Bank of the United States

811 Vermont Avenue, NW, Room 1167

Washington, DC 20571

Tel: 202/565-3571

Fax: 202/565-3584

Committee on Renewable Energy Commerce and Trade (CORECT)

CORECT is an interagency working group comprised of representatives from 14 U.S. Federal government agencies, chaired by the U.S. Department of Energy. CORECT works closely with the U.S. Export Council for Renewable Energy (US/ECRE), an industry consortium of seven renewable energy trade associations, to promote renewable energy exports in international markets and ensure that renewable energy technologies and applications are integrated in development projects.

Contact: Ronald Bowes, Director

Office of Technical Assistance

Energy Efficiency and Renewable Energy

U.S. Department of Energy

1000 Independence Avenue, SW, Room 5E-036

Washington, DC 20585

Tel: $202 / 586-2959$

Fax: 202/586-1605 
Committee on Energy Efficiency Commerce and Trade (COEECT)

COEECT is an interagency working group comprised of representatives from 14 U.S. Federal government agencies, chaired by the U.S. Department of Energy. COEECT works closely with the Energy Efficiency Export Council to undertake market assessment for energy efficiency products and services, identify project financing from federal and multilateral institutions, and address the specific needs of the energy efficiency products and services industry.

Contact: Ronald Bowes, Director

Office of Technical Assistance

Energy Efficiency and Renewable Energy

U.S. Department of Energy

1000 Independence Avenue, SW, Room 5E-036

Washington, DC 20585

Tel: 202/586-2959

Fax:202/586-1605

\section{A.2. Multilateral Sources}

Asian Development Bank

ADB does perform pre-investment and/or feasibility studies usually for projects in which it is interested in investing. Interested parties should track the ADB procurement notice bulletins. To obtain information on $\mathrm{ADB}$ procurement opportunities, contact the representatives below.

Contact: Janet Thomas, Procurement Liaison

Asian Development Bank

\#6 ADB Avenue

1501 Madaluyuong Metro

Manila Philippines

Tel: 632/890-9364

Fax: 632/890-9713

-or-

Mary Alice Healy

U.S. Department of Commerce

Room 1107

Washington, DC 20230

Tel: $202 / 482-4333$

Fax: 202/273-0927

\section{A.3. In Country Sources}

No known available sources. 


\section{B. PROJECT FINANCE - PRIVATE SECTOR:}

\section{B.1. U.S. Government Sources}

Overseas Private Investment Corporation (OPIC)

OPIC is not authorized to operate in Pakistan.

\section{Export-Import Bank's Project Finance Program}

EXIM Bank recently launched a new program to finance projects that are dependent solely on the project cash flow of the particular project for repayment. Projects under this program can not rely on sovereign guarantees to assure repayment as is normally required under typical EXIM Bank export credit packages. Under this program, EXIM offers (1) allowance of up to 15 percent foreign content in the US package; (2) financing of interest accrued during construction related to the EXIM Bank financing facilities; (3) financing of host country local costs of up to 15 percent of the US contract value; (4) maximum repayment term allowed under the OECD guidelines; (5) no minimum/maximum limitations on project size; (6) flexible coverage and equity arrangements; (7) exposure fee commensurate with risk; and (8) rapid application processing.

Contact: Glen Matsumoto, Vice President

Project Finance Division

Export-Import Bank of the United States

811 Vermont Avenue, NW

Washington, DC 20571

Tel: 202/565-3690

Fax:202/565-3695

The investment funds listed below have been capitalized primarily with funds from U.S. government and multilateral organizations:

AIG Asian Infrastructure Fund

The AIG Asian Infrastructure Fund makes equity and convertible debt investments in private infrastructure and related projects in priority sectors in countries in the Asia Pacific region, including Pakistan. The Fund is capitalized at US\$1,086 million. The core investors are the American International Group (AIG), the Singapore Government Investment Companies, US pension funds, and the Brunci government. 35 percent to 50 percent of the Fund is expected to be invested in China. The balance will be dedicated to investments in Indonesia, Malaysia, the Philippines, Taiwan, Thailand, and other Asian countries, including Pakistan. The Fund is prepared to invest in greenfield, expansion, privatizations, pre-IPO projects, and participate in cofinancing opportunities. Typical investments range from US $\$ 10$ to US $\$ 100$ million for primary projects and US $\$ 2$ million to US $\$ 20$ million for secondary projects. The Fund may invest up to US $\$ 100$ million in any single project but will participate as a minority stockholder. Targeted sectors are power and related energy, telecommunications, transportation, natural resource development, petrochemical, environment, and infrastructure related facilities. 


\section{Contact in U.S.: $\quad$ AIG-Asian Infrastructure Fund}

c/o Emerging Markets Corporation

Scott Glecken, Director - Markcting

1828 L Street, N.W., Suite 900

Washington, D.C. 20036

Tel: 202/331-9051

Fax: 202/331-9250

\section{Peregrine Asian Infrastructure Fund}

The Peregrine Fund closed on US $\$ 500$ million in November, 1994 and expects to raise an additional US $\$ 500$ million, for a total expected capitalization of US $\$ 1$ billion. The International Finance Corporation, Asian Development Bank, and the Asian Infrastructure Development Fund Ltd. are the initial investors of the Fund and Peregrine Investments and Frank Russell Investments are its sponsors. The main objective of the Fund is to achieve long-term capital appreciation through infrastructure investments in Asia, including Pakistan. The Fund will invest in non-listed equity or cquity linked securities of entities that are engaged in the development, ownership, or operation of infrastructure facilities. Target sectors are primarily power, transportation, and telecommunications.

\section{Contact: Edward Landry}

Asian Infrastructure Fund Management Company Ltd.

16-18 Queen's Road Central

New World Tower

Hong Kong

Tel: $852 / 2825-1169$

Fax: 852/2845-0786

-or-

Peregrine Brokerage Inc.

780 Third Avenue, Suite 2601

New York, NY 10017

Tel: $212 / 593-5920$

Fax: 212/593-5932

Global Power Investments Fund

GE Capital Corporation and Soros Fund Management established Global Power Investments Fund, a new venture capital fund, which will make subordinated debt and equity investments in privately-owned electric power generating facilities in emerging markets, including Pakistan. The Fund is capitalized at $\$ 500$ million with initial capital contributions by GE Capital, Soros Fund Management, Quantum Industrial Holdings, and the International Finance Corporation (IFC). Additional capital will be raised to reach a total capitalization target of at least $\$ 2.5$ billion. The Fund will primarily invest in the new construction of power plants (gas-fired, coal-fired, and possibly cogeneration), although it may invest in existing facilities. Global Power Investments will look to projects that use commercially-viable, proven technologies. GE Capital will take the lead on identifying projects in the field, providing the analysis of risks and retums, negotiating the terms of transaction, and managing the portfolio of investments. Soros Fund and the IFC will provide investment advisory services and assist in making investment decisions on behalf of the Fund. 
Contact: Dick Fowler

GE Capital Corporation

1600 Summer Street, 6th Floor

Stamford, CT 06927

Tel: 203/357-4385

Fax: 203/357-6289

-or-

Jose Brena

GE Capital Corporation

London Office (handles investments in Pakistan)

Tel: 44-171-973-9410

Fax: 44-171-973-9428

\section{B.2. Multilateral Sources}

International Finance Corporation (IFC)

IFC, a member of the World Bank, is the largest source of direct financing for private sector projects in developing countries, including Pakistan. Unlike the World Bank, IFC lends directly to private companies and does not request guarantees from host-country governments. It can provide loans, make equity investments in private businesses, and mobilize additional loan and equity financing in international financial markets through syndication efforts. Although IFC invests and lends on market terms, it finances projects unable to obtain sufficient funding on reasonable terms from other sources. Increasingly, the IFC is working through intermediary financial facilities in order to support smaller scale projects and supporting cofinance arrangements with the World Bank (GEF) and EBRD.

Loans and equity investments are usually limited to no more than 25 percent of project cost. IFC's minimum investment project support is $\$ 10$ million. Funds may be used for foreign or local expenditures related to overall project costs, i.e, fixed assets, permanent working capital, interest during construction, and pre-operating cost. IFC can invest up to 35 percent of the share capital as long as it is not the major shareholder. It turns over its equity often by sale to local investors when the investment has matured. Both fixed and variable rate loans are offered; rates are determined on a commercial basis. Terms normally run from seven to twelve years.

Contact for Pakistan: Mr. Javed Hamid

Manager, Division I

Central Asia, Middle East and North Africa Department

International Finance Corporation

1850 Eye Street, NW, Room K-6009

Washington, DC 20433

Tel: $202 / 473-0400$

Fax: 202/334-8744 
Contact in Pakistan

Mr. Michael Essex

IFC Resident Representative

20 A Shahrah-e-Jamhuriat

Ramna 5 (G 5/1)

Islamabad, Pakistan

Tel: 92-51/214-320

Fax: $92-51 / 216-420$

Contact for Environment: Mr. Martyn Riddle, Manager

Environmental Unit

International Finance Corporation

1850 Eye Street, NW

Washington, DC 20433

Tel: 202/473-0661

Fax: 202/676-9495

\section{B.3. In Country Sources}

No known available sources.

\section{PROJECT FINANCE - PUBLIC SECTOR:}

\section{C.1. U.S. Government Sources}

No known available sources.

\section{C.2. Multilateral Sources}

\section{Asian Development Bank (ADB)}

Headquartered in Manila, the Philippines, the Asian Development Bank is a development finance institution whose mandate is to promote the economic and social progress of its 53 development member countries in the Asian and Pacific region. On behalf of its member countries, the Bank aims to (1) make loans and equity investments to enhance their economic and social development; (2) promote investment of public and private capital to meet their developmental goals; (3) provide technical assistance for the preparation and execution of their development projects and programs, and advisory services; and (4) respond to requests for assistance in coordinating their development policies and plans.

Contact for Pakistan: $\quad$ Ms. Dorte Kabell

Programs Officer, Division I

Infrastructure, Energy and Financial Sectors Department (West)

Tel: $632 / 632-6354$

Fax: 632/631-7961 or 631-6816 
Contact for Energy:

Headquarters:

Postal Address:
Mr. H. Satish Rao

Senior Financial Analyst, Energy Division

Infrastructure, Energy and Financial Sectors Department (West)

Tel: $632 / 632-6436$ or 6440

Fax: 632/636-2335

\section{ADB Avenue, Mandaluyong \\ 0401 Metro Manila, Philippines}

P.O. Box 789

Manila Central Post Office

0980 Manila, Philippines

International Bank for Reconstruction and Development (WORLD BANK)

The World Bank, a multilateral lending agency, is the largest source of financial and technical assistance to the public sector in developing countries. The Bank also makes policy-oriented structural and sectoral adjustment loans to support market-oriented institutional reforms. The Bank lends to member governments for public sector development projects, not to the private sector. The Bank affiliate that lends to the private sector is the IFC. Loans are made only to governments or to agencics that can obtain a government guarantee for repayment. Bank funds are used by member governments to import food and equipment, fund project construction, and obtain consultant services. Interest rates on Bank loans are set a half a percentage point above the Bank's average cost of borrowing and repayment terms are normally twelve to fifteen years, including a three to five year grace period.

Contact for Pakistan: $\quad$ Mr. Shahrokh Fardoust (Interim Country Officer)

Country Department I (SA1)

South Asia Regional Office

1818 H Street, NW, Room D10-101

Washington, DC 20433

Tel: 202/473-3049

Fax: 202/477-6530

Contact for Energy: $\quad$ Mr. Per Ljung

Energy \& Project Finance

Country Department I (SA1)

South Asia Regional Office

The World Bank

1818 H Street, NW, Room D 10-003

Washington, DC 20433

Tel: $202 / 458-1933$

Fax:202/477-8598 
Resident Representative: Mr. Sadiq Ahmed, Chief

World Bank Resident Mission

$20 \mathrm{~A}$

Shahrah-e-Jamhuriat

Islamabad, Pakistan

Tel: 92-51/819-781, 782-6

Fax: $92-51 / 824-137$

\section{Global Environment Facility (GEF)}

Established in 1990, GEF provides grants for investment projects and technical assistance to assist developing countries to address four main global (transboundary) environmental problems: global warming, pollution of international waters, destruction of biological diversity, and depletion of the ozone layer. GEF is comanaged by the World Bank, U.N. Development Programme, and the U.N. Environmental Programme. To qualify for funding under the GEF, projects must be innovative, demonstrate the effectiveness of a particular technology or approach, and fall into one of the four priority areas. GEF funding is possible if the project offers substantial global benefits, but is unlikely to be viable without some concessional funding or if a project is economically viable but requires supplemental finance to bring about global benefits.

GEF projects can either be free-standing, components of World Bank projects, or pass through the IFC to support private sector ventures that have both important demonstration benefits and host government endorsement. Free-standing GEF projects are limited to $\$ 10$ million, and GEF components of World Bank projects must not exceed $\$ 30$ million. GEF funds can leverage regular Bank projects by paying the additional cost of incorporating environmentally benign technologies in Bank-supported projects. GEF funds would cover the difference in cost between what the host country is willing to pay and the cost of the benign technology. Use of GEF funds through the IFC can be used if the sponsor/lender could not otherwise underwrite the risk under prevailing market conditions; funds cannot be used to avert normal commercial risks.

Contact: Mr. Robin Broadfield, Regional Coordinator

Africa \& South Asia

Global Environment Coordination Division

The World Bank

1818 H Street, NW, Room S-2131

Washington, DC 20433

Tel: $202 / 473-4355$

Fax: 202/522-3256 


\title{
C.3. In Country Sources
}

Below is a listing of the major state banks and specialized development financial institutions:

\author{
Agricultural Development Bank of Pakistan \\ Faisal Avenue \\ POB 1400 \\ Islamabad Pakistan
}

Tel: 92-51/826-896

Fax: not available

Telex: 5618

Industrial Development Bank of Pakistan

State Life Building

2 Wallace Road

off I.I. Chundrigar Road

POB 5082

Karachi 2, Pakistan

Tel: $\quad 92-21 / 241-9160$

Fax: 92-21/241-1990

Telex: 20722

Investment Corporation of Pakistan

NBP Building, 5th Floor

I.I. Chundrigar Road, POB 5410

Karachi 74400

Tel: $\quad 92-21 / 241-5860$

Fax: 92-21/241-1684

Telex: 20079

National Bank of Pakistan (NBP)

NBP Building

I.I. Chundrigar Road

POB 4937

Karachi 2, Pakistan

Tel: $\quad 92-21 / 241-6780$

Fax: 92-21/211-6769

Telex: 23732

National Investment (Unit Trust) Ltd.

NBP Building, 6th Floor

I.I. Chundrigar Road

POB 5671

Karachi, Pakistan

Tel: $\quad$ 92-21/241-2056

Fax: not available

Telex: 24476 
Pakistan Industrial Credit and Investment Corporation Ltd.

State Life Building No. 1

I.I. Chundrigar Road

POB 5080

Karachi 2, Pakistan

Tel: $\quad 92-21 / 241-4200$

Fax: $92-21 / 213-478$

Telex: 2710

Pak-Libya Holding Co. Ltd.

Finance and Trade Centre

5th Floor, Tower "C"

Shahrah-e-Faisal

POB 10425

Karachi, Pakistan

Tel: $\quad 92-21 / 510-409$

Fax: $92-21 / 568-2389$

Telex: 29763

Saudi Pak Industrial and Agricultural Investment Co. (Pvt) Ltd.

Quaid-e-Azam Avenue

Blue Area

Islamabad, Pakistan

Tel: $\quad 92-51 / 815-001$

Fax: 92-51/815-005

Telex: 5663

State Bank of Pakistan Ltd.

I.I. Chundrigar Road

POB 4456

Karachi 2, Pakistan

Tel: $\quad 92-21 / 241-4141$

Fax: 92-21/241-7865

Telex: 23730

United Bank Ltd.

State Life Building, No.1

I.I. Chundrigar Road

POB 4306

Karachi 64200, Pakistan

Tel: $\quad 92-21 / 241-7100$

Fax: $92-21 / 241-3483$

Telex: 20034 


\section{COFINANCING:}

\section{D.1. U.S. Government Sources}

Not applicable.

\section{D.2. Multilateral Sources}

International Bank for Reconstruction and Development (World Bank)

Although the Bank mainly lends to governments and government agencies, it can also provide guarantees to commercial lenders for public and private sector projects. The Bank's guarantee program currently covers loans totalling $\$ 1$ billion. As a way to attract private sector capital and encourage direct foreign investments in developing countries, the Bank's Executive Directors approved a proposal making guarantees a mainstream instrument of Bank opcrations in September 1994. There are two types of guarantees offered: (1) partial risk guarantee that covers non-performance of sovereign contractual obligations or other contractual non-performance problems in a project and (2) partial credit guarantee which extends maturities beyond what private lenders could otherwise provide.

By covering risks that the market would not bear, the Bank's guarantec program helps reduce the cost of financing projects by guaranteeing against contractual non-performance, offers flexibility to structure project financing by extending maturities, and attracts private sources of capital by sharing risks of undertaking infrastructure projects in developing countries.

Contact: Nina Shapiro, Manager

Project Finance Group

CoFinancing and Financial Advisory Department

The World Bank

1818 H Street, NW, Room Q-5131

Washington, DC 20433

Tel: 202/473-1650

Fax:202/477-0218

\section{Asian Development Bank (ADB)}

The ADB syndicates participations in loans and provides parallel and joint financing as a way to enable commercial banks to take on the risks of lending to developing countries and its clients access additional financing sources from international capital markets, and to raise long-term finance on reasonable terms on behalf of its clients.

\section{Contact: Eikki Jappinen, Manager \\ Cofinance Unit \\ Asian Development Bank}

6 ADB Avenue, Mandaluyong

0401 Metro Manila, Philippines

Tel: $632 / 632-6314$

Fax: 632/636-2456 
International Finance Corporation (IFC)

The IFC syndicates participations in loans and provides parallel and joint financing as a way to enable commercial banks to take on the risks of lending to developing countries and its clients access additional financing sources from international capital markets, and to raise long-term finance on reasonable terms on behalf of its clients.

Contact: Richard Parry

Syndications Department

International Finance Corporation

1850 Eye Street, NW, Room I-3103

Washington, DC 20433

Tel: 202/473-0398

Fax: 202/334-8713

\section{D.3. In Country Sources}

Not applicable.

\section{E. TRADE FINANCE:}

\section{E.1. U.S. Government Sources}

\section{Export-Import Bank of the United States (EXIM)}

EXIM is an independent, U.S. government agency that provides support for U.S. exports through shortand medium-term export credit insurance, medium- and long-term loan guarantees, medium- and long-term direct and intermediary loans, working capital guarantees, and project financing.

EXIM will only help finance exports of U.S. goods and services containing at least 50 percent U.S. content. The entire value of the shipment is covered under short-term export credit programs, while 100 percent of the U.S. content of the shipment is covered under medium- and long-term programs provided that EXIM's support does not exceed 85 percent of the export pricc. EXIM's short-term programs cover up to 360 days, medium-term programs cover up to five ycars, and long-term programs cover twelve years.

Through EXIM's traditional financing programs, U.S. exports to Pakistan can be financed by EXIM's short-term credit insurance; medium-term loans, guarantees, and insurance; and long-term loans and guarantees. Limited recourse project risk financing is also available for Pakistan (see description B.1 under "Project Finance - Private Sector" section of this directory).

For transactions involving sales to state-owned enterprises or public entities in Pakistan, EXIM requires the Pakistani Ministry of Finance to provide a sovereign guarantee. For transactions involving sales to a private entity in Pakistan, EXIM may require a Pakistani commercial bank to act as obligor or guarantor. It is advisable to check with EXIM as to those Pakistani banks with which EXIM will honor guarantees. Under certain circumstances, EXIM will accept a private Pakistani company as obligor, without a commercial bank guarantee, provided that, in EXIM's view, the company is creditworthy, financially sound, and has an established commercial track record. 
EXIM's short-term credit insurance is available for exports of bulk agricultural commodities and for quasicapital goods (on terms up to 360 days) and of consumer goods, spare parts, and raw materials (on terms up to 180 days). EXIM's medium-term loans, guarantees, and insurance are available to support exports of capital equipment on terms up to five years. Under medium-term programs, terms may be extended to seven years. EXIM's long-term loan and guarantee programs for exports of capital equipment are available at terms up to ten years.

Most of EXIM's medium-term and long-term transactions have been in support of transactions in the power sector and exports of industrial machinery equipment. EXIM will also consider alternative energy projects in energy efficiency and renewable energy that incorporate geothermal, solar, wind, hydroelectric, cogeneration and biomass technologies.

EXIM financing may not be used to support the sales of defense articles and services to any country for offensive or defensive military purposes, except for anti-narcotics purposes under limited circumstances.

Contact: Frank Wilson, Senior Business Development Officer

Business Development Office

Export-Import Bank of the United States

811 Vermont Avenue, NW, Room 929

Washington, DC 20571

Tel: $202 / 565-3900$

Fax: 202/565-3931

\section{E.2. Multilateral Sources}

Trade finance is primarily through cofinancing export credit facilities available through multilateral institutions.

\section{Other Sources may include:}

The Export-Import Bank of Japan (JEXIM)

The Export-Import Bank of Japan (JEXIM) is an independent governmental financial institution of Japan. The mandate of JEXIM is to provide a wide range of financial services to supplement and encourage financing by commercial banks and other financial institutions and to foster Japanese overseas investment and international financial cooperation for economic development worldwide. JEXIM is very aggressive in cofinancing deals with international development and commercial banks and has been quite active in the Pakistani market. Of particular interest to U.S. companies are untied loans available under JEXIM's "Funds for Development" initiative. This $\$ 120$ billion initiative was launched in June, 1993 to promote economic progress in developing countries through funding for Japanese exporters or project sponsors to finance projects in developing countries. However, financing is also provided to U.S. and other foreign exporters on an "untied" basis, i.e., without a direct link to a Japanese exportcr, importer, or project sponsor.

Contact in U.S.: $\quad$ Export-Import Bank of Japan

2000 Pennsylvania Avenue, NW, Suite 3350

Washington, DC 20006

Tel: 202/331-8547

Fax: 202/775-1990 
Contact for Pakistan*: $\quad$ Export-Import Bank of Japan (JEXIM)

8th Floor, Meridien Commercial Tower

8 Windsor Place

New Delhi 110001 India

Tel: $91-11 / 371-0430$ or $371-4165$

Fax:91-11/371-4895

*(There is no JEXIM Office in Pakistan; JEXIM's office in New Delhi, India would likely handle inquiries on Pakistan.)

\section{E.3. In Country Sources}

Below is a list of leading Pakistani commercial banks*:

Allied Bank of Pakistan Ltd.

12th-17th Floor

Abbasi Shaheed Road

off Shahrah-e-Faisal

Karachi 75530, Pakistan

Tel: $\quad 92-21 / 511-031$

Fax: 92-21/568-0134

Telex: 21746

Askari Commercial Bank Ltd.

AWT Plaza, The Mall

POB 1084

Rawalpindi, Pakistan

Tel: 92-51/586-634

Fax: 92-51/563-704

Telex: 54647

Habib Bank Ltd.

11 Habib Bank Plaza

I.I. Chundrigar Road

Karachi 75650, Pakistan

Tel: $\quad 92-21 / 219-111$

Fax: 92-21/241-4191

Telex: 20786

Muslim Commercial Bank Ltd.

Adamjee House

I.I. Chundrigar Road

POB 4976

Karachi 74000, Pakistan

Tel: $\quad 92-21 / 241-4091$

Fax: 92-21/241-3116

Telex: 21750 
Prime Commercial Bank Ltd.

Library Block, Aiwan-e-Iqbal Complex

Egerton Road

Lahore, Pakistan

Tel: $\quad 92-42 / 636-8725$

Fax: $\quad 92-42 / 636-9162$

Telex: 47721

\section{Soneri Bank Ltd.}

4th Floor

IEP Building

97-B/D-1

Gulberg III

Lahore, Pakistan

Tel: $\quad 92-42 / 571-3101$

Fax: $92-42 / 571-3095$

Telex: 44447

*This list does not represent a complete listing of Pakistani commercial banks; it is meant to highlight those leading Pakistani banks most active in project financing and loan syndications.

Below is a list of U.S. and foreign investment and commercial banks that are active in the Pakistani market:*

\section{ABN-AMRO Bank NV}

\section{Avari Plaza}

242-243, Farima Jinnah Road

POB 4096

Karachi 74000, Pakistan

Tel: $\quad 92-21 / 568-7580$

Fax: $92-21 / 568-3432$

Telex: 21008

\section{ANZ Grindlays Bank PLC}

I.I. Chundrigar Road

POB 5556

Karachi 2, Pakistan

Tel: 92-21-241-2671

Fax: $\quad 92-21 / 241-4914$

Telex: 2755 
American Express Bank Ltd.

Shaheen Commercial Complex

Dr. Ziauddin Ahmed Road

POB 4847

Karachi, Pakistan

Tel: $92-21 / 263-0343$

Fax: $92-21 / 263-1803$

Telex: 2610

Bank of America National Trust and Savings Association

New Jubliee Insurance House, 5th Floor

I.I. Chundrigar Road

POB 3715

Karachi, Pakistan

Tel: $92-21 / 241-2520$

Fax: $92-21 / 241-5371$

Telex: 21081

Bank of Tokyo Ltd.

Shaheen Foundation Building, 1st Floor

M.R. Kayani Road, POB 4232

Karachi, Pakistan

Tel: $\quad 92-21 / 520-171$

Fax: not available

Telex: 2653

\section{Banque Indosuez}

Muhammadi House

I.I. Chundrigar Road

POB 6942

Karachi 74000, Pakistan

Tel: $92-21 / 241-7155$

Fax: 92-21/241-7503

Telex: 20090

CS First Boston

55 East 52nd Street

New York, NY 10055

Tel: 212/909-2415

Fax: 212/318-0915

Chase Manhattan Bank

Shaheen Commercial Complex

M.R. Kayani Road, POB 1161

Karachi, Pakistan

Tel: $92-21 / 263-3071$

Fax: 92-21/263-1393

Telex: 25620 
Citibank, NA

State Life Building

I.I. Chundrigar Road

POB 4889

Karachi, Pakistan

Tel: $\quad 92-21 / 241-2883$

Fax: 92-21/241-8903

Telex: 2745

Deutsche Bank AG

Unitower Building

Unicentre Building

I.I. Chundrigar Road, POB 4925

Karachi, Pakistan

Tel: $\quad 92-21 / 241-9611$

Fax: $92-21 / 241-6970$

Telex: 20453

\section{GE Capital}

20 St. James' Street

London SW1A 1ES England

Tel: 44-171/839-7066

Fax: 44-171/839-3624

The Hong Kong and Shanghai Banking Corporation Ltd.

Shaheen Commercial Complex

M.R. Kayani Road, POB 121

Karachi, Pakistan

Tel: $\quad 92-21 / 263-0386$

Fax: 92-21/263-1526

Telex: 24112

Kidder, Peabody \& Co.

10 Hanover Square

New York, NY 10007

Tel: $212 / 693-2001$

Fax: 212/571-3217

Merrill Lynch \& Co.

North Tower

World Financial Center

New York, NY 10281-1327

Tel: $212 / 449-7890$

Fax:212/449-7148 
Salomon Brothers

7 World Trade Center

30th Floor

New York, NY 10048

Tel: $212 / 783-5879$

Fax: $212 / 783-4164$

Smith Barney Asia, Inc.

9/F, Gloucester Tower

The Landmark, Central

Hong Kong HK

Tel: $852 / 822-6400$

Fax: 852/869-0997

Societe Generale

3rd Floor, PNSC Building

Maulvi Tamizuddin Khan Road, POB 6766

Karachi 74000, Pakistan

Tel: $92-21 / 551-846$

Fax: 92-21/551-672

Telex: 29605

\section{Standard Charter Bank}

I.I. Chundrigar Road

POB 4896

Karachi 2, Pakistan

Tel: $\quad 92-21 / 241-6485$

Fax: 92-21/241-1593

Telex: 2890

*This list does not represent a complete listing of U.S. and foreign banks active in the Pakistani market; it is meant to highlight those leading U.S. and foreign banks most active in project financing and loan syndications.

\section{F. TECHNICAL ASSISTANCE \& TRAINING:}

\section{F.1. U.S. Government Sources}

U.S. Agency for International Development (USAID)

USAID is not authorized to operate in Pakistan. 


\section{F.2. Multilateral Sources}

World Bank

- Energy Efficiency Cross-Support Team

In addition to the South Asia Office of the World Bank, the Industrial and Energy Department of the Central Vice-Presidency for Finance and Private Sector Development of the World Bank provides cross-support for sectoral and geographic departments of the Bank. Cross-support is provided for project lending, institutional development, and technical assistance related to energy efficiency and conservation, and rural, household, and renewable encrgy initiatives. This cross-support team can provide implementation support for energy efficiency components of on-going Bank project lending and technical assistance as well as assess and monitor state-of-the-art technology and energy management practices for key end-user sectors.

Contact: Karl Jechoutek, Division Chief

Industry and Energy Department

Vice Presidency for Finance and Private Sector Development

World Bank

Washington, DC 20433

Tel: $202 / 458-6391$

Fax: 202/477-0542

\section{F.3. In Country Sources}

No known available sources. 


\section{G. INDEX}

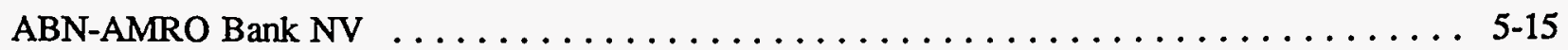

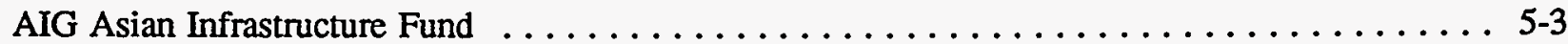

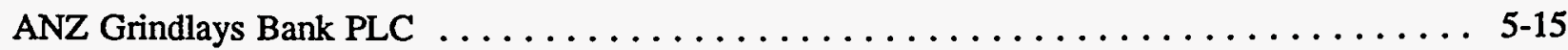

Agricultural Development Bank of Pakistan . . . . . . . . . . . . . . . . . 5-9

Allied Bank of Pakistan Ltd. . . . . . . . . . . . . . . . . . . . . . 5-14

American Express Bank Ltd. . . . . . . . . . . . . . . . . . . . . . . 5-16

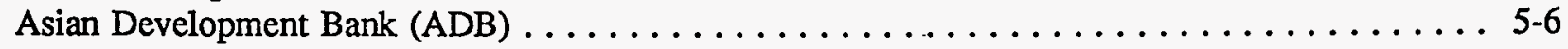

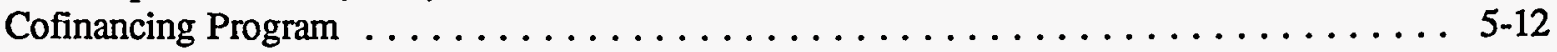

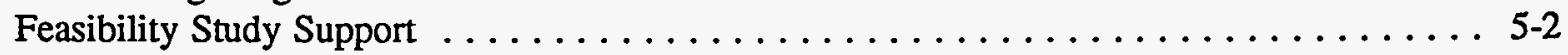

Askari Commercial Bank Ltd. . . . . . . . . . . . . . . . . . . . . . . . . . 5-14

Bank of American National Trust and Savings Association . . . . . . . . . . . 5-16

Bank of Tokyo Ltd. . . . . . . . . . . . . . . . . . . . . . . . . . . . 5-16

Banque Indosuez . . . . . . . . . . . . . . . . . . . . . . . . . . . 5-16

CS First Boston . . . . . . . . . . . . . . . . . . . . . . . . . 5-16

Chase Manhattan Bank . . . . . . . . . . . . . . . . . . . . . . . . . 5-16

Citibank NA . . . . . . . . . . . . . . . . . . . . . . . . . . . . . 5-17

Committee on Energy Efficiency Commerce and Trade (COEECT) . . . . . . . . . . . . . . 5-2

Committee on Renewable Energy Commerce and Trade (CORECT) . . . . . . . . . . . 5 5-1

Deutsche Bank AG . . . . . . . . . . . . . . . . . . . . . . . . . . 5-17

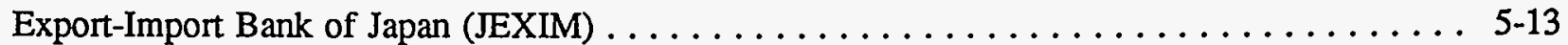

Export-Import Bank of the United States (EXIM) $\ldots \ldots \ldots \ldots \ldots \ldots \ldots \ldots \ldots \ldots \ldots \ldots$. $\ldots \ldots$. $\ldots \ldots$

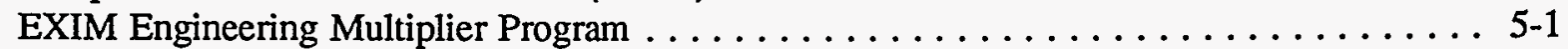

EXIM Project Finance Program $\ldots \ldots \ldots \ldots \ldots \ldots \ldots \ldots \ldots \ldots \ldots \ldots \ldots$

GE Capital ................................ $5-17$

Global Environment Facility $(\mathrm{GEF}) \ldots \ldots \ldots \ldots \ldots \ldots \ldots \ldots \ldots \ldots \ldots \ldots \ldots \ldots$

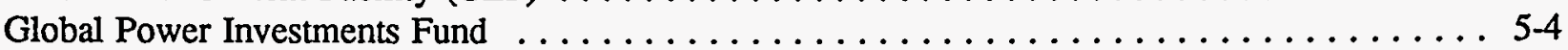

Habib Bank Ltd. . . . . . . . . . . . . . . . . . . . . . . . . . $5-14$

The Hong Kong and Shanghai Banking Corporation Ltd. . . . . . . . . . . . . 5-17

Industrial Development Bank of Pakistan . . . . . . . . . . . . . . . . . 5 5-9

International Bank for Reconstruction and Development (WORLD BANK) . . . . . . . 5-7,11,19

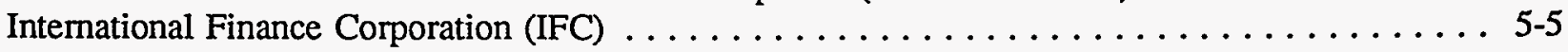

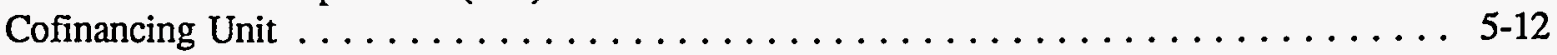

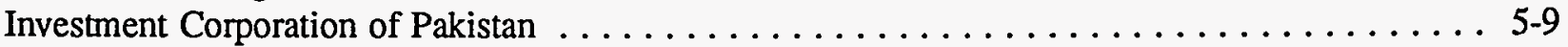

Kidder, Peabody \& Co. . . . . . . . . . . . . . . . . . . . . . . . . 5-17

Merrill Lynch \& Co. . . . . . . . . . . . . . . . . . . . . . . . . . . . 5-17

Muslim Commercial Bank Ltd. . . . . . . . . . . . . . . . . . . . . 5-14

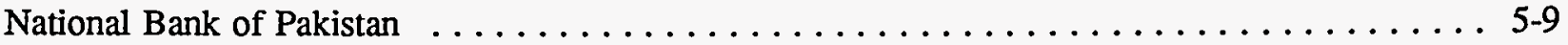

National Investment (Unit Trust) Ltd. . . . . . . . . . . . . . . . . . . . . . 5-9

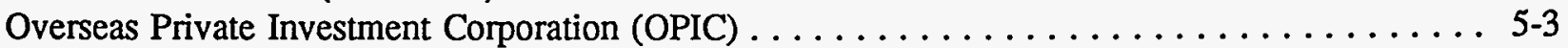

Pakistan Industrial Credit and Investment Corporation Ltd. . . . . . . . . . . . . . . 5-10

Pak-Libya Holding Co. Ltd. . . . . . . . . . . . . . . . . . . . . . . . . . . 5-10

Peregrine Asian Infrastructure Fund $\ldots \ldots \ldots \ldots \ldots \ldots \ldots \ldots \ldots \ldots \ldots \ldots$

Prime Commercial Bank Ltd. . . . . . . . . . . . . . . . . . . . . . . . . . 5-15

Salomon Brothers $\ldots \ldots \ldots \ldots \ldots \ldots \ldots \ldots \ldots \ldots \ldots \ldots \ldots \ldots \ldots \ldots$

Saudi Pak Industrial and Agricultural Investment Co. (Pvt) Ltd. . . . . . . . . . . 5-10

Smith Bamey Asia, Inc. . . . . . . . . . . . . . . . . . . . . $5-18$ 


\section{PAKISTAN}

Societe Generale . . . . . . . . . . . . . . . . . . . . . . . . . $5-18$

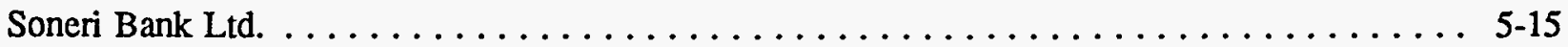

Standard Charter Bank .............................. 5-18

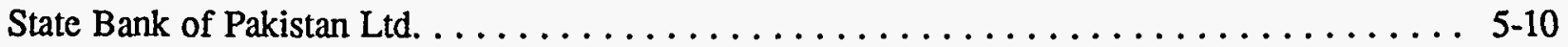

U.S. Agency for International Development (USAID) $\ldots \ldots \ldots \ldots \ldots \ldots \ldots \ldots \ldots \ldots$

U.S. Trade and Development Agency (TDA) $\ldots \ldots \ldots \ldots \ldots \ldots \ldots \ldots \ldots \ldots \ldots \ldots$

United Bank Ltd. . . . . . . . . . . . . . . . . . . . . . . . . . . . 5 5-10

World Bank . . . . . . . . . . . . . . . . . . . . . . . . . . . . . 5-7

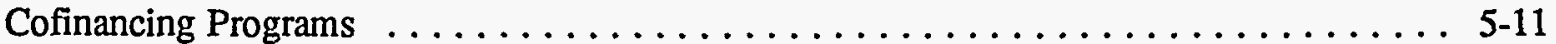

Energy Efficiency Cross-Support Team $\ldots \ldots \ldots \ldots \ldots \ldots \ldots \ldots \ldots \ldots$. . . . . . . . . . . . . . 
